\title{
Schoolverlaters tussen onderwijs en arbeidsmarkt 1995.
}

\author{
Citation for published version (APA):
}

Researchcentrum voor Onderwijs en Arbeidsmarkt, ROA. (1996). Schoolverlaters tussen onderwijs en arbeidsmarkt 1995. Kerngegevens. Researchcentrum voor Onderwijs en Arbeidsmarkt, Faculteit der Economische Wetenschappen. ROA Reports No. 003B https://doi.org/10.26481/umarep.1996003B

\section{Document status and date:}

Published: 01/01/1996

DOI:

10.26481/umarep.1996003B

Document Version:

Publisher's PDF, also known as Version of record

\section{Please check the document version of this publication:}

- A submitted manuscript is the version of the article upon submission and before peer-review. There can be important differences between the submitted version and the official published version of record.

People interested in the research are advised to contact the author for the final version of the publication, or visit the DOI to the publisher's website.

- The final author version and the galley proof are versions of the publication after peer review.

- The final published version features the final layout of the paper including the volume, issue and page numbers.

Link to publication

\footnotetext{
General rights rights.

- You may freely distribute the URL identifying the publication in the public portal. please follow below link for the End User Agreement:

www.umlib.nl/taverne-license

Take down policy

If you believe that this document breaches copyright please contact us at:

repository@maastrichtuniversity.nl

providing details and we will investigate your claim.
}

Copyright and moral rights for the publications made accessible in the public portal are retained by the authors and/or other copyright owners and it is a condition of accessing publications that users recognise and abide by the legal requirements associated with these

- Users may download and print one copy of any publication from the public portal for the purpose of private study or research.

- You may not further distribute the material or use it for any profit-making activity or commercial gain

If the publication is distributed under the terms of Article $25 \mathrm{fa}$ of the Dutch Copyright Act, indicated by the "Taverne" license above, 


\section{Kerngegevens}

\section{Schoolverlaters tussen onderwijs en arbeidsmarkt 1995}

ROA-R-1996/3B

Researchcentrum voor Onderwijs en Arbeidsmarkt

Faculteit der Economische Wetenschappen en Bedrijfskunde Rijksuniversiteit Limburg

Maastricht, mei 1996 
ISBN 90-5321-173-X 


\section{Inhoudsopgave}

Voorwoord I

1 Bestemming van schoolverlaters $\quad 1$

1A Percentage vrouwen in de uitstroom van schoolverlaters per opleidingscluster

1B Percentage vrouwen in de uitstroom van schoolverlaters per opleidingsrichting 4

2A Percentage allochtonen in de uitstroom van schoolverlaters, $\begin{array}{ll}\text { verbijzonderd naar geslacht per opleidingscluster } & 6\end{array}$

2B Percentage allochtonen in de uitstroom van schoolverlaters, $\begin{array}{ll}\text { verbijzonderd naar geslacht per opleidingsrichting } & 7\end{array}$

3A Leeftijd van schoolverlaters per opleidingscluster 9

3B Leeftijd van schoolverlaters per opleidingsrichting 10

4A Vooropleiding van schoolverlaters per opleidingscluster 12

4B Vooropleiding van schoolverlaters per opleidingsrichting 13

5A Gewenste bestemming van schoolverlaters per opleidingscluster 15

5B Gewenste bestemming van schoolverlaters per opleidingsrichting 16

6A Bestemming van schoolverlaters per opleidingscluster 18

6B Bestemming van schoolverlaters per opleidingsrichting 19

6C Bestemming van schoolverlaters, verbijzonderd naar regio per opleidingscluster

6D Bestemming van schoolverlaters, verbijzonderd naar vooropleiding per opleidingscluster

\section{Doorstroom naar vervolgonderwijs}

7A Vervolgopleiding van verder lerende schoolverlaters per opleidingscluster

$7 \mathrm{~B}$ Vervolgopleiding van verder lerende schoolverlaters per opleidingsrichting

7C Belangrijkste vervolgopleidingsrichtingen van verder lerende schoolverlaters per opleidingscluster

7D Belangrijkste vervolgopleidingsrichtingen van verder lerende schoolverlaters per opleidingsrichting

8A Oordeel van de verder lerende schoolverlaters over de aansluiting van de afgesloten opleiding met de vervolgopleiding per opleidingscluster

8B Oordeel van de verder lerende schoolverlaters over de aansluiting van de afgesloten opleiding met de vervolgopleiding per opleidingsrichting

9 Percentage verder lerende schoolverlaters dat van mening is dat aan de onderscheiden aspecten van de afgesloten opleiding meer aandacht zou moeten worden besteed per opleidingscluster

10A Duale opleiding van verder lerende schoolverlaters per opleidingscluster

10B Duale opleding van verder lerende schoolverlaters, verbijzonderd naar leerlingstelsel en in-service onderwijs per opleidingscluster 


\section{Kans op werk en verkrijgen van werk}

11A Duur van de intredewerkloosheid van schoolverlaters die zich aanbieden op de arbeidsmarkt per opleidingscluster

11B Duur van de intredewerkloosheid van schoolverlaters die zich aanbieden op de arbeidsmarkt per opleidingsrichting

12A Werkloosheid onder schoolverlaters per opleidingscluster, 1994 en 1995

12B Werkloosheid onder schoolverlaters per opleidingsrichting, 1994 en 1995

$13 \mathrm{~A}$ Wijze van het verkrijgen van een baan per opleidingscluster

13B Wijze van het verkrijgen van een baan per opleidingsrichting

\section{Kwaliteit van het werk}

14A Bruto maandloon van de werkende schoolverlaters per opleidingscluster

14B Bruto maandloon van de werkende schoolverlaters per opleidingsrichting

15A Bruto uurloon van de werkende schoolverlaters per opleidingscluster

15B Bruto uurloon van de werkende schoolverlaters per opleidingsrichting

16A Vereist opleidingsniveau van werkende schoolverlaters per opleidingscluster 74

16B Vereist opleidingsniveau van werkende schoolverlaters per opleidingsrichting

17A Vereiste opleidingsrichting van werkende schoolverlaters per opleidingscluster

17B Vereiste opleidingsrichting van werkende schoolverlaters per opleidingsrichting

18A Soort dienstverband van de werkende schoolverlaters per opleidingscluster

18B Soort dienstverband van de werkende schoolverlaters per opleidingsrichting

19A Percentage werkende schoolverlaters met een vaste aanstelling per opleidingscluster

19B Percentage werkende schoolverlaters met een vaste aanstelling per opleidingsrichting

20A Wekelijkse arbeidsduur van werkende schoolverlaters per opleidingscluster

20B Wekelijkse arbeidsduur van werkende schoolverlaters per opleidingsrichting

\section{Bedrijven en beroepen}

21A Belangrijkste bedrijfsgroepen waarin schoolverlaters werkzaam zijn per opleidingscluster

21B Belangrijkste bedrijfsgroepen waarin schoolverlaters werkzaam zijn per opleidingsrichting

22A Belangrijkste beroepsgroepen waarin schoolverlaters werkzaam zijn per opleidingscluster

22B Belangrijkste beroepsgroepen waarin schoolverlaters werkzaam zijn per opleidingsrichting 
23A Grootte van de organisatie waarin schoolverlaters werkzaam zijn per opleidingscluster

23B Grootte van de organisatie waarin schoolverlaters werkzaam zijn per opleidingsrichting

\section{Structureel risico}

24A Bedrijfsgroepenspreiding van de werkende schoolverlaters per opleidingscluster

24B Bedrijfsgroepenspreiding van de werkende schoolverlaters per opleidingsrichting

25A Beroepsgroepenspreiding van de werkende schoolverlaters per opleidingscluster

25B Beroepsgroepenspreiding van de werkende schoolverlaters per opleidingsrichting

26A Conjunctuurgevoeligheid van de werkgelegenheid in de bedriffsklassen waar schoolverlaters werkzaam zijn per opleidingscluster

26B Conjunctuurgevoeligheid van de werkgelegenheid in de bedrijfsklassen waar schoolverlaters werkzaam zijn per opleidingsrichting

\section{Kwalitatieve aansluiting opleiding-beroep}

27A Oordeel van de werkende schoolverlaters over de aansluiting van de afgesloten opleiding met de huidige baan per opleidingscluster

27B Oordeel van de werkende schoolverlaters over de aansluiting van de afgesloten opleiding met de huidige baan per opleidingsrichting

28 Percentage werkende schoolverlaters dat van mening is dat aan de onderscheiden aspecten van de afgesloten opleiding meer aandacht zou moeten worden besteed per opleidingscluster

29A Potentiële mobiliteit van werkende schoolverlaters per opleidingscluster

29B Potentiële mobiliteit van werkende schoolverlaters per opleidingsrichting

30A Deelname aan een aanvullende opleiding of cursus door werkenden per opleidingscluster

30B Deelname aan een aanvullende opleiding of cursus door werkenden per opleidingsrichting

\section{Koppelschema Kerngegevens 1995 / Schoolverlaters op de arbeidsmarkt 1994}




$$
=
$$




\section{Voorwoord}

\section{Toelichting}

Deze bijlage Kerngegevens bij het rapport Schoolverlaters tussen onderwijs en arbeidsmarkt 1995 geeft een overzicht van de belangrijkste uitkomsten van de enquête Registratie van Uitstroom en Bestemming van Schoolverlaters (RUBS) die in het voorjaar van 1995 is gehouden onder schoolverlaters van het schooljaar 1993/'94 van het Algemeen Voortgezet Onderwijs (AVO), het Voorbereidend Beroepsonderwijs (VBO) en de korte, tussen en lange variant van het Middelbaar Beroepsonderwijs (MBO). Rapportage en bijlage vormen samen het vervolg op de RUBS-rapportages die vanaf 1993 door het Landelijk Dienstverlenend Centrum voor Studie- en Beroepskeuzevoorlichting zijn uitgegeven.

Kerngegevens is in drie delen onderverdeeld. Deel 1 geeft de belangrijkste informatie over de bestemming van schoolverlaters. Vervolgens gaat deel 2 in op de doorstroom van schoolverlaters naar het vervolgonderwijs. Deel 3 beschrijft de intrede van schoolverlaters op de arbeidsmarkt. Achtereenvolgens wordt daarbij een overzicht gegeven van de kans op werk en het verkrijgen van werk, kwaliteit van werk, bedrijven en beroepen van schoolverlaters, het structurele risico op de arbeidsmarkt en de kwalitatieve aansluiting tussen de afgesloten opleiding en het huidige beroep. Voorts is een drietal bijlagen opgenomen. Dit betreft respectievelijk een lijst met begrippen, de gehanteerde schriftelijke vragenlijst (alleen de MBO-lijst) en een 'omnummertabel' van deze Kerngegevens met het statistisch supplement van de RUBS-rapportage 1994, waardoor de vergelijking met de resultaten van vorige jaren wordt vergemakkelijkt ${ }^{1}$.

De tabellen in deze Kerngegevens zijn per onderwerp genummerd. Daarbij zijn de meeste tabellen zowel per opleidingscluster als op het gedetailleerdere niveau van opleidingsrichtingen gepresenteerd. Bovendien bevat vrijwel elke tabel een korte toelichting, die bijvoorbeeld verwijst naar de corresponderende vraag in de enquête. In alle tabellen is tevens het gewogen aantal waarnemingen gepresenteerd waarop de gegevens zijn gebaseerd. Door gebruik te maken van deze gewogen aantallen kunnen de gegevens op eenvoudige wijze voor een samengestelde groep worden berekend. Het (ongewogen) aantal respondenten vormt overigens wel de leidraad om de betrouwbaarheid van de informatie te toetsen. Wanneer de percenteerbasis van bepaalde gegevens op minder dan 25 respondenten betrekking heeft, wordt geen informatie gepresenteerd.

\section{$\overline{\text { Verantwoording }}$}

Het RUBS-project wordt, behalve door de deelnemende scholen, financieel mogelijk

Hierbij wordt er op gewezen dat bij de gegevens met betrekking tot de intrede op de arbeidsmarkt in tegensteling tot voorgaande jaren - expliciet rekening is gehouden met de huidige bestemming van schoolverlaters. In de voorliggende rapportage hebben deze gegevens uitsluitend betrekking op degenen die niet een voltijd vervolgopleiding zijn gaan volgen. 
gemaakt door het Ministerie van Onderwijs, Cultuur en Wetenschappen, het Landelijk Dienstverlenend Centrum voor Studie- en Beroepskeuzevoorlichting (LDC) en het Ministerie van Landbouw, Natuurbeheer en Visserij.

Binnen het RUBS-project is het LDC verantwoordelijk voor de toepassing van het instrument voor individuele scholen en voor de studie- en beroepskeuzevoorlichting. Het ROA heeft de wetenschappelijke verantwoording over RUBS als onderzoek. Beide instituten werken samen met DESAN Marktonderzoek, dat met name zorgdraagt voor de verzending van de vragenlijsten, de dataverwerking en het samenstellen van de schoolspecifieke rapportages. Bij het ROA was dr. R.K.W. van der Velden tot 1 augustus 1995 projectleider van het RUBS-project. Sinds die datum wordt het onderzoek geleid door drs. E.J.T.A. Willems. Deze rapportage Kerngegevens is onder begeleiding van drs. M.S.M. van Smoorenburg en drs. E.J.T.A. Willems samengesteld door A.M. Kleijnen. 
Kerngegevens / Schoolverlaters tussen onderwijs en arbeidsmarkt 1995

1 Bestemming van schoolverlaters 
Kerngegevens / Schoolverlaters tussen onderwiis en arbeidsmarkt 1995 
Tabel 1A

Percentage vrouwen in de uitstroom van schoolverlaters per opleidingscluster

Opleidingscluster

\begin{tabular}{l} 
AVO \\
MAVO \\
HAVO \\
WWO \\
VBO \\
landbouw \\
techniek \\
economie \\
dienstverlening/verzorging \\
overig \\
MBO-kort \\
landbouw \\
techniek \\
economie \\
dienstverlening/verzorging \\
overig \\
MBO-tussen en -lang \\
landbouw \\
techniek \\
economie \\
dienstverlening/verzorging \\
overig \\
\hline
\end{tabular}

Totaal vrouw

Totaal

$\mathrm{N}=100 \%$

$55 \quad 6177$

$57-2813$

$55-1825$

491538

$44-2524$

$45-222$

$7 \quad 1187$

$68-503$

$98-581$

$34-32$

$57 \quad 952$

$48-19$

16245

$66-436$

$96-124$

$67-128$

$54-3133$

$33-189$

$14-929$

$59-1041$

$94 \quad 774$

74200

52

12786 
Tabel 1B

Percentage vrouwen in de uitstroom van schoolverlaters per opleidingsrichting

Opleidingsrichting

vrouw

Totaal

$\mathrm{N}=100 \%$

$\%$

AVo

MAVO

HAVO

VWO

57

55

49

2813

1825

VBO

landbouw

bouwtechniek

mechanische techniek

elektrotechniek

motorvoertuigentechniek

consumptieve techniek

installatietechniek

grafische techniek

overig techniek

administratie

verkoop

handel

verzorging

uiterlijke verzorging

mode en kleding

overig

6

236

222

274

168

174

27

281

115

106

456

51

74

32

MBO-kort

landbouw

elektrotechniek

motorv. techniek

consumptieve techniek

werktuigbouw

overig techniek

(detail)handel

administratie

verzorging

overig dienstverlening/verzorging

overig

MBO-tussen en -lang

plantenteelt

veehouderij

levensmiddelentechnologie

bloemschikken

dierenverzorging

groene ruimte

overig landbouw

bouwkunde

elektrotechniek

werktuigbouwkunde

weg- en waterbouwkunde

motorvoertuigentechniek

mechanische techniek

grafische techniek
43

53

20

19

12

37

5

145

283

191

26

43

6 
Tabel 1B (vervolg)

Percentage vrouwen in de uitstroom van schoolverlaters per opleidingsrichting

Opleidingsrichting

vrouw

Totaal

$\mathrm{N}=100 \%$

\begin{tabular}{|c|c|c|}
\hline & $\%$ & \\
\hline proces- en laboratoriumtechniek & 26 & 83 \\
\hline nautisch & - & - \\
\hline mode \& kleding (techn) & 97 & 65 \\
\hline overig techniek & 5 & 64 \\
\hline administratie & 46 & 183 \\
\hline secretariaat & 99 & 116 \\
\hline commercieel & 55 & 110 \\
\hline economisch-juridisch & 52 & 27 \\
\hline vrije afstudeerrichting & 45 & 48 \\
\hline toerisme en recreatie & 90 & 61 \\
\hline logistiek & 20 & 9 \\
\hline (detail)handel & 50 & 280 \\
\hline horeca & 53 & 54 \\
\hline overig economie & 59 & 152 \\
\hline agogisch werk & 93 & 213 \\
\hline verzorging & 99 & 166 \\
\hline assistenten gezondheidszorg & 99 & 103 \\
\hline mode en kleding & 100 & 69 \\
\hline activiteitenbegeleiding & 92 & 51 \\
\hline facilitaire dienstverlening & 69 & 36 \\
\hline uiterlijke verzorging & 99 & 33 \\
\hline sociale arbeid & 82 & 34 \\
\hline verpleging & 87 & 47 \\
\hline overig dienstverlening/verzorging & - & - \\
\hline overig & 74 & 200 \\
\hline Totaal & 52 & 12786 \\
\hline
\end{tabular}


Tabel 2B

Percentage allochtonen in de uitstroom van schoolverlaters, verbijzonderd naar geslacht per opleidingsrichting

Opleidingsrichting

\begin{tabular}{cccccc} 
man & $\begin{array}{c}\text { man } \\
\mathrm{N}=100 \%\end{array}$ & vrouw & $\begin{array}{c}\text { vrouw } \\
\mathrm{N}=100 \%\end{array}$ & Totaal & $\begin{array}{c}\text { Totaal } \\
\mathrm{N}=100 \%\end{array}$ \\
$\%$ & & $\%$ & & $\%$ & \\
\hline
\end{tabular}

AVO

MAVO

HAVO

WWO

1203
811
777

$\begin{array}{rr}4 & 1611 \\ 3 & 1011 \\ 4 & 759\end{array}$

$\begin{array}{ll}5 & 2813 \\ 3 & 1822 \\ 2 & 1536\end{array}$

VBO

landbouw

bouwtechniek

mechanische techniek

elektrotechniek

motorvoertuigentechniek

consumptieve techniek

installatietechniek

grafische techniek

611

759

1822

overig techniek

administratie

verkoop

handel

verzorging

uiterlijke verzorging

mode en kleding

overig

$\begin{array}{rr}2 & 121 \\ 1 & 221 \\ 11 & 219 \\ 10 & 268 \\ 4 & 165 \\ 1 & 128 \\ - & - \\ 10 & 35 \\ - & - \\ 13 & 81 \\ - & - \\ 14 & 51 \\ - & - \\ - & - \\ - & -\end{array}$

$\begin{array}{rrrr}1 & 101 & 1 & 222 \\ - & - & 1 & 236 \\ - & - & 11 & 222 \\ - & - & 10 & 274 \\ - & - & 4 & 168 \\ 0 & 46 & 1 & 174 \\ - & - & - & - \\ - & - & 8 & 44 \\ - & - & - & - \\ 13 & 200 & 13 & 281 \\ 12 & 86 & 9 & 115 \\ 9 & 55 & 11 & 106 \\ 3 & 444 & 3 & 456 \\ 12 & 50 & 12 & 50 \\ 25 & 70 & 24 & 72 \\ - & - & 0 & 32\end{array}$

MBO-kort

landbouw

elektrotechniek

motorv. techniek

consumptieve techniek

werktuigbouw

overig techniek

(detail)handel

administratie

verzorging

dienstverlening/verzorging

overig

MBO-tussen en -lang plantenteelt

veehouderij

levensmiddelentechnologie

bloemschikken

dierenverzorging

groene ruimte

overig landbouw

bouwkunde

elektrotechniek

werktuigbouwkunde

weg- en waterbouwkunde

motorvoertuigentechniek

mechanische techniek

$\begin{array}{rrrrrr}1 & 36 & 0 & 7 & 0 & 43 \\ 0 & 42 & 0 & 11 & 0 & 53 \\ 0 & 10 & 0 & 10 & 0 & 20 \\ - & - & 0 & 16 & 0 & 19 \\ - & - & 0 & 10 & 0 & 12 \\ 0 & 31 & 0 & 6 & 0 & 37 \\ - & - & - & - & 0 & 5 \\ 2 & 127 & - & - & 1 & 145 \\ 4 & 276 & - & - & 4 & 283 \\ 3 & 184 & - & - & 3 & 191 \\ 10 & 25 & - & - & 9 & 26 \\ 5 & 43 & - & - & 5 & 43 \\ 17 & 5 & - & - & 15 & 6\end{array}$


Tabel 2B (vervolg)

Percentage allochtonen in de uitstroom van schoolverlaters, verbijzonderd naar geslacht per opleidingsrichting

\begin{tabular}{|c|c|c|c|c|c|c|}
\hline Opleidingsrichting & $\begin{array}{c}\operatorname{man} \\
\%\end{array}$ & $\underset{N=100 \%}{\operatorname{man}}$ & $\begin{array}{c}\text { vrouw } \\
\%\end{array}$ & $\begin{array}{c}\text { vrouw } \\
N=100 \%\end{array}$ & $\begin{array}{c}\text { Totaal } \\
\%\end{array}$ & $\begin{array}{c}\text { Totaal } \\
\mathrm{N}=100 \%\end{array}$ \\
\hline grafische techniek & 2 & 12 & 3 & 10 & 2 & 23 \\
\hline proces- en laboratoriumtechniek & 8 & 61 & 4 & 22 & 7 & 83 \\
\hline nautisch & - & - & - & - & - & - \\
\hline mode \& kleding (techn) & - & - & 1 & 63 & 1 & 65 \\
\hline overig techniek & 3 & 59 & - & - & 5 & 62 \\
\hline administratie & 3 & 98 & 2 & 85 & 3 & 183 \\
\hline secretariaat & - & - & 4 & 115 & 4 & 116 \\
\hline commercieel & 5 & 50 & 4 & 60 & 5 & 110 \\
\hline economisch-juridisch & - & - & 17 & 14 & 14 & 27 \\
\hline vrije afstudeerrichting & 4 & 27 & 2 & 21 & 3 & 48 \\
\hline toerisme en recreatie & 3 & 6 & 1 & 55 & 1 & 61 \\
\hline logistiek & 0 & 7 & - & - & 0 & 9 \\
\hline (detail)handel & 2 & 141 & 2 & 139 & 2 & 280 \\
\hline horeca & 1 & 25 & 0 & 29 & 0 & 54 \\
\hline overig economie & 3 & 62 & 11 & 90 & 8 & 152 \\
\hline agogisch werk & 0 & 16 & 2 & 196 & 2 & 212 \\
\hline verzorging & - & - & 0 & 164 & 0 & 166 \\
\hline assistenten gezondheidszorg & - & - & 6 & 102 & 6 & 103 \\
\hline mode en kleding & - & - & 4 & 69 & 4 & 69 \\
\hline activiteitenbegeleiding & - & - & 1 & 46 & 1 & 51 \\
\hline facilitaire dienstverlening & 0 & 11 & 1 & 25 & 1 & 36 \\
\hline uiterlijke verzorging & - & - & 4 & 32 & 4 & 32 \\
\hline sociale arbeid & - & - & 7 & 28 & 6 & 34 \\
\hline verpleging & 0 & 6 & 2 & 41 & 2 & 47 \\
\hline dienstverlening/verzorging & - & - & - & - & - & - \\
\hline overig & 6 & 52 & 4 & 148 & 5 & 200 \\
\hline Totaal & 5 & 6075 & 5 & 6696 & 5 & 12771 \\
\hline
\end{tabular}

- = geen gegevens vanwege kleine aantallen

\section{Toelichting}

Vraag in de enquête: Tot welke bevolkingsgroep reken jij jezelf?

ledereen die zichzelf niet tot de Nederlandse bevolkingsgroep rekent wordt als allochtoon aangemerkt. 
Tabel 3A

Leeftijd van schoolverlaters per opleidingscluster

\begin{tabular}{|c|c|c|c|c|c|c|c|c|c|}
\hline Opleidingscluster & $\begin{array}{c}<=17 \text { jr } \\
\%\end{array}$ & $\begin{array}{c}18 \text { jr } \\
\%\end{array}$ & $\begin{array}{c}19 \mathrm{jr} \\
\%\end{array}$ & $\begin{array}{c}20 \mathrm{jr} \\
\%\end{array}$ & $\begin{array}{c}21 \text { jr } \\
\%\end{array}$ & $\begin{array}{c}22 \text { jr } \\
\%\end{array}$ & $\begin{array}{c}>=23 \text { jr } \\
\%\end{array}$ & $\begin{array}{l}\text { gemid- } \\
\text { deld }\end{array}$ & $\begin{array}{c}\text { Totaal } \\
\mathrm{N}=100 \%\end{array}$ \\
\hline AVO & 41 & 23 & 22 & 12 & 2 & 0 & 0 & 18,0 & 6008 \\
\hline MAVO & 79 & 16 & 4 & 0 & 0 & 0 & 0 & 17,0 & 2751 \\
\hline HAVO & 14 & 36 & 31 & 17 & 2 & 0 & 1 & 18,6 & 1758 \\
\hline VWO & 0 & 21 & 44 & 27 & 6 & 1 & 0 & 19,2 & 1499 \\
\hline VBO & 63 & 28 & 7 & 2 & 0 & 0 & 0 & 17,3 & 2462 \\
\hline landbouw & 69 & 27 & 3 & 1 & 0 & 0 & 0 & 17,2 & 219 \\
\hline techniek & 56 & 32 & 9 & 2 & 1 & 0 & 0 & 17,5 & 1161 \\
\hline economie & 63 & 26 & 8 & 1 & 1 & 0 & 0 & 17,3 & 485 \\
\hline dienstverlening/verzorging & 76 & 20 & 3 & 1 & 0 & 0 & 0 & 17,1 & 564 \\
\hline overig & 56 & 41 & 3 & 0 & 0 & 0 & 0 & 17,4 & 32 \\
\hline MBO-kort & 3 & 17 & 26 & 30 & 15 & 5 & 4 & 19,7 & 907 \\
\hline landbouw & 0 & 7 & 33 & 36 & 13 & 6 & 5 & 20,1 & 17 \\
\hline techniek & 1 & 11 & 23 & 32 & 16 & 9 & 7 & 20,1 & 233 \\
\hline economie & 2 & 12 & 27 & 34 & 18 & 5 & 3 & 19,8 & 417 \\
\hline dienstverlening/verzorging & 1 & 12 & 36 & 28 & 15 & 3 & 4 & 19,7 & 116 \\
\hline overig & 15 & 48 & 18 & 11 & 3 & 2 & 3 & 18,6 & 123 \\
\hline MBO-tussen en -lang & 0 & 1 & 10 & 29 & 27 & 19 & 15 & 21,1 & 3022 \\
\hline landbouw & 1 & 2 & 5 & 28 & 33 & 17 & 12 & 21,0 & 181 \\
\hline techniek & 0 & 0 & 4 & 17 & 26 & 28 & 25 & 21,7 & 902 \\
\hline economie & 0 & 2 & 12 & 29 & 29 & 18 & 11 & 20,9 & 1002 \\
\hline dienstverlening/verzorging & 0 & 0 & 12 & 39 & 25 & 13 & 10 & 21,0 & 745 \\
\hline overig & 1 & 9 & 22 & 41 & 16 & 5 & 6 & 20,0 & 192 \\
\hline Totaal & 32 & 18 & 16 & 15 & 9 & 5 & 4 & 18,8 & 12399 \\
\hline
\end{tabular}

Toelichting

Het gaat hier om de leeftijd van de schoolverlaters op de onderzoeksdatum. 
Tabel 3B

Leeftijd van schoolverlaters per opleidingsrichting

\begin{tabular}{lrrrrrrrrr} 
Opleidingsrichting & $<=17 \mathbf{j r}$ & $\mathbf{1 8} \mathbf{j r}$ & $\mathbf{1 9} \mathbf{j r}$ & $\mathbf{2 0} \mathbf{j r}$ & $\mathbf{2 1} \mathbf{j r}$ & $\mathbf{2 2} \mathbf{j r}$ & $\mathbf{> = 2 3} \mathbf{~ j r}$ & $\begin{array}{c}\text { gemid- } \\
\text { deld }\end{array}$ & $\begin{array}{c}\text { Totaal } \\
\mathbf{N}=\mathbf{1 0 0} \%\end{array}$ \\
& $\%$ & $\%$ & $\%$ & $\%$ & $\%$ & $\%$ & $\%$ & & \\
\hline AVO & & & & & & & & & \\
MAVO & 79 & 16 & 4 & 0 & 0 & 0 & 0 & 17,0 & 2751 \\
HAVO & 14 & 36 & 31 & 17 & 2 & 0 & 1 & 18,6 & 1758 \\
WWO & 0 & 21 & 44 & 27 & 6 & 1 & 0 & 19,2 & 1499
\end{tabular}

\section{VBO}

landbouw

bouwtechniek

mechanische techniek

elektrotechniek

motorvoertuigentechniek

consumptieve techniek

installatietechniek

grafische techniek

overig techniek

administratie

verkoop

handel

verzorging

uiterlijke verzorging

mode en kleding

overig

$\begin{array}{rrrrrrrrr}69 & 27 & 3 & 1 & 0 & 0 & 0 & 17,2 & 219 \\ 74 & 16 & 9 & 1 & 1 & 0 & 0 & 17,2 & 229 \\ 51 & 33 & 12 & 3 & 0 & 1 & 0 & 17,6 & 222 \\ 64 & 29 & 4 & 1 & 1 & 0 & 0 & 17,3 & 266 \\ 59 & 33 & 6 & 0 & 0 & 0 & 2 & 17,5 & 165 \\ 28 & 48 & 16 & 6 & 1 & 0 & 0 & 18,0 & 171 \\ - & - & - & - & - & - & - & - & - \\ 41 & 34 & 14 & 8 & 2 & 0 & 2 & 18,0 & 42 \\ - & - & - & - & - & - & - & - & - \\ 68 & 25 & 5 & 2 & 0 & 0 & 0 & 17,2 & 266 \\ 68 & 21 & 7 & 2 & 2 & 0 & 0 & 17,2 & 115 \\ 44 & 36 & 17 & 0 & 2 & 0 & 0 & 17,7 & 104 \\ 77 & 19 & 3 & 1 & 0 & 0 & 0 & 17,1 & 443 \\ 74 & 24 & 3 & 0 & 0 & 0 & 0 & 17,2 & 51 \\ 69 & 25 & 7 & 0 & 0 & 0 & 0 & 17,1 & 70 \\ 56 & 41 & 3 & 0 & 0 & 0 & 0 & 17,4 & 32\end{array}$

MBO-kort

landbouw

elektrotechniek

motorv. techniek

consumptieve techniek

werktuigbouw

overig techniek

(detail)handel

administratie

verzorging

overig dienstverlening/

verzorging

overig

$\begin{array}{rrrrrrrrr}0 & 7 & 33 & 36 & 13 & 6 & 5 & 20,1 & 17 \\ 1 & 8 & 26 & 28 & 18 & 8 & 11 & 20,3 & 28 \\ 3 & 12 & 25 & 25 & 25 & 6 & 3 & 19,9 & 49 \\ 1 & 12 & 29 & 29 & 17 & 9 & 3 & 19,9 & 64 \\ 0 & 18 & 15 & 36 & 8 & 10 & 13 & 20,3 & 50 \\ 0 & 5 & 21 & 44 & 14 & 9 & 7 & 20,3 & 43 \\ 4 & 19 & 30 & 28 & 15 & 4 & 1 & 19,5 & 149 \\ 0 & 8 & 25 & 37 & 19 & 6 & 4 & 20,0 & 269 \\ 1 & 11 & 38 & 30 & 14 & 3 & 3 & 19,7 & 94 \\ & & & & & & & & \\ - & - & - & - & - & - & - & - & - \\ 15 & 48 & 18 & 11 & 3 & 2 & 3 & 18,6 & 123\end{array}$

MBO-tussen en -lang

plantenteelt

veehouderij

levensmiddelentechnologie

bloemschikken

dierenverzorging

groene ruimte

overig landbouw

bouwkunde

elektrotechniek

werktuigbouwkunde

weg- en waterbouwkunde

motorvoertuigentechniek

mechanische techniek

$\begin{array}{rrr}4 & 34 & 36 \\ 6 & 29 & 42 \\ 5 & 24 & 29 \\ 9 & 34 & 33 \\ 1 & 25 & 20 \\ 5 & 20 & 28 \\ 10 & 23 & 17 \\ 1 & 23 & 40 \\ 3 & 15 & 29 \\ 5 & 14 & 21 \\ 2 & 6 & 12 \\ 1 & 8 & 28 \\ 5 & 16 & 19\end{array}$

$\begin{array}{rrrr}15 & 9 & 20,9 & 41 \\ 13 & 5 & 20,7 & 50 \\ 22 & 17 & 21,2 & 20 \\ 14 & 8 & 20,8 & 18 \\ 26 & 19 & 21,1 & 12 \\ 20 & 23 & 21,4 & 35 \\ 20 & 27 & 21,9 & 5 \\ 20 & 15 & 21,3 & 141 \\ 33 & 20 & 21,6 & 272 \\ 25 & 34 & 22,0 & 186 \\ 57 & 24 & 22,4 & 26 \\ 23 & 40 & 22,3 & 42 \\ 19 & 42 & 22,2 & 5\end{array}$


Tabel 3B (vervolg)

Leeftijd van schoolverlaters per opleidingsrichting

\begin{tabular}{|c|c|c|c|c|c|c|c|c|c|}
\hline Opleidingsrichting & $\begin{array}{c}<=17 \text { jr } \\
\%\end{array}$ & $\begin{array}{c}18 \mathrm{jr} \\
\%\end{array}$ & $\begin{array}{c}19 \text { jr } \\
\%\end{array}$ & $\begin{array}{c}20 \text { jr } \\
\%\end{array}$ & $21 \mathrm{jr}$ & $\begin{array}{c}22 \text { jr } \\
\%\end{array}$ & $\begin{array}{c}>=23 \text { jr } \\
\%\end{array}$ & $\begin{array}{l}\text { gemid- } \\
\text { deld }\end{array}$ & $\begin{array}{c}\text { Totaal } \\
\mathrm{N}=100 \%\end{array}$ \\
\hline grafische techniek & 1 & 0 & 2 & 11 & 22 & 26 & 39 & 22,2 & 22 \\
\hline proces- en laboratoriumtechniel & iek 0 & 0 & 1 & 16 & 18 & 35 & 31 & 22,1 & 82 \\
\hline nautisch & - & - & - & - & - & - & - & - & - \\
\hline mode \& kleding (techn) & 0 & 0 & 7 & 43 & 30 & 8 & 13 & 20,8 & 61 \\
\hline overig techniek & 0 & 0 & 11 & 10 & 17 & 37 & 25 & 21,7 & 63 \\
\hline administratie & 0 & 3 & 18 & 30 & 29 & 14 & 6 & 20,5 & 174 \\
\hline secretariaat & 0 & 1 & 14 & 41 & 31 & 9 & 3 & 20,4 & 111 \\
\hline commercieel & 0 & 2 & 12 & 36 & 31 & 9 & 10 & 20,7 & 109 \\
\hline economisch-juridisch & 0 & 5 & 4 & 29 & 33 & 25 & 4 & 20,8 & 26 \\
\hline vrije afstudeerrichting & 0 & 0 & 6 & 24 & 30 & 22 & 18 & 21,3 & 45 \\
\hline toerisme en recreatie & 0 & 0 & 1 & 13 & 32 & 27 & 27 & 21,8 & 59 \\
\hline logistiek & 0 & 0 & 12 & 31 & 38 & 9 & 9 & 20,7 & 9 \\
\hline (detail)handel & 0 & 1 & 9 & 26 & 27 & 25 & 11 & 21,0 & 268 \\
\hline horeca & 0 & 0 & 1 & 6 & 19 & 27 & 47 & 22,7 & 52 \\
\hline overig economie & 0 & 3 & 17 & 38 & 30 & 12 & 1 & 20,3 & 148 \\
\hline agogisch werk & 0 & 0 & 14 & 39 & 27 & 11 & 9 & 20,7 & 205 \\
\hline verzorging & 0 & 0 & 15 & 48 & 21 & 9 & 7 & 20,9 & 161 \\
\hline assistenten gezondheidszorg & 0 & 1 & 13 & 35 & 24 & 15 & 12 & 20,9 & 100 \\
\hline mode en kleding & 0 & 1 & 15 & 44 & 22 & 14 & 4 & 20,5 & 66 \\
\hline activiteitenbegeleiding & 0 & 0 & 7 & 26 & 31 & 13 & 23 & 23,4 & 48 \\
\hline facilitaire dienstverlening & 0 & 2 & 12 & 27 & 33 & 16 & 10 & 21,5 & 33 \\
\hline uiterlijke verzorging & 0 & 0 & 7 & 28 & 33 & 18 & 14 & 21,1 & 32 \\
\hline sociale arbeid & 0 & 0 & 8 & 25 & 26 & 18 & 24 & 21,6 & 34 \\
\hline verpleging & 0 & 0 & 7 & 46 & 22 & 15 & 9 & 20,8 & 46 \\
\hline overig dienstverlening/verzorgin & ging- & - & - & - & - & - & - & - & - \\
\hline overig & 1 & 9 & 22 & 41 & 16 & 5 & 6 & 20,0 & 192 \\
\hline Totaal & 32 & 18 & 16 & 15 & 9 & 5 & 4 & 18,8 & 12399 \\
\hline
\end{tabular}

- = geen gegevens vanwege kleine aantallen 
Tabel 4A

Vooropleiding van schoolverlaters per opleidingscluster

\begin{tabular}{|c|c|c|c|c|c|c|c|c|}
\hline \multirow[t]{2}{*}{ Opleidingscluster } & \multirow{2}{*}{$\begin{array}{c}\text { MAVO } \\
\%\end{array}$} & \multirow{2}{*}{$\begin{array}{c}\text { HAVO } \\
\\
\%\end{array}$} & \multirow{2}{*}{$\begin{array}{c}\text { WWO } \\
\%\end{array}$} & \multirow{2}{*}{$\begin{array}{l}\text { VBO } \\
\%\end{array}$} & \multirow{2}{*}{$\begin{array}{c}\text { MBO- } \\
\text { kort } \\
\%\end{array}$} & \multirow{2}{*}{$\begin{array}{c}\text { MBO- } \\
\text { tussen } \\
\text { en -lang } \\
\%\end{array}$} & \multirow{2}{*}{$\begin{array}{l}\text { overig } \\
\qquad \%\end{array}$} & \multirow[t]{2}{*}{$\begin{array}{c}\text { Totaal } \\
\mathrm{N}=100 \%\end{array}$} \\
\hline & & & & & & & & \\
\hline MBO-kort & 28 & 1 & 0 & 66 & 2 & 1 & 2 & 729 \\
\hline landbouw & 17 & 1 & 0 & 73 & 2 & 1 & 6 & 16 \\
\hline techniek & 28 & 2 & 0 & 65 & 4 & 0 & 1 & 203 \\
\hline economie & 35 & 0 & 0 & 59 & 2 & 3 & 1 & 335 \\
\hline dienstverlening/verzorging & 4 & 0 & 0 & 86 & 3 & 0 & 7 & 94 \\
\hline overig & 25 & 0 & 0 & 75 & 0 & 0 & 0 & 80 \\
\hline MBO-tussen en -lang & 56 & 15 & 0 & 25 & 2 & 2 & 0 & 2858 \\
\hline landbouw & 39 & 7 & 0 & 47 & 2 & 4 & 0 & 175 \\
\hline techniek & 51 & 14 & 0 & 30 & 1 & 4 & 0 & 830 \\
\hline economie & 56 & 28 & 1 & 13 & 1 & 1 & 0 & 962 \\
\hline dienstverlening/verzorging & 61 & 5 & 0 & 29 & 4 & 1 & 1 & 713 \\
\hline overig & 79 & 1 & 0 & 19 & 1 & 2 & 0 & 178 \\
\hline Totaal & 50 & 12 & 0 & 33 & 2 & 2 & 1 & 3586 \\
\hline
\end{tabular}


Tabel 4B

Vooropleiding van schoolverlaters per opleidingsrichting

\begin{tabular}{|c|c|c|c|c|c|c|c|c|}
\hline \multirow[t]{2}{*}{ Opleidingsrichting } & \multirow[t]{2}{*}{$\begin{array}{c}\text { MAVO } \\
\text { \% }\end{array}$} & \multirow[t]{2}{*}{$\begin{array}{c}\text { HAVO } \\
\text { \% }\end{array}$} & \multirow[t]{2}{*}{$\begin{array}{c}\text { VWO } \\
\%\end{array}$} & \multirow[t]{2}{*}{$\begin{array}{c}\text { VBO } \\
\text { \% }\end{array}$} & \multirow[t]{2}{*}{$\begin{array}{c}\text { MBO- } \\
\text { kort } \\
\%\end{array}$} & \multirow[t]{2}{*}{$\begin{array}{c}\text { MBO- } \\
\text { tussen } \\
\text { en -lang } \\
\%\end{array}$} & \multirow[t]{2}{*}{$\begin{array}{l}\text { overig } \\
\qquad \%\end{array}$} & \multirow[t]{2}{*}{$\begin{array}{c}\text { Totaal } \\
\mathrm{N}=100 \%\end{array}$} \\
\hline & & & & & & & & \\
\hline \multicolumn{9}{|l|}{ MBO-kort } \\
\hline landbouw & 17 & 1 & 0 & 73 & 2 & 1 & 6 & 16 \\
\hline elektrotechniek & 26 & 0 & 0 & 73 & 1 & 0 & 0 & 25 \\
\hline motorv. techniek & 33 & 3 & 0 & 60 & 3 & 0 & 0 & 46 \\
\hline consumptieve techniek & 36 & 1 & 0 & 49 & 10 & 0 & 3 & 55 \\
\hline werktuigbouw & 16 & 0 & 0 & 81 & 3 & 0 & 0 & 39 \\
\hline overig techniek & 21 & 3 & 0 & 71 & 0 & 3 & 3 & 38 \\
\hline (detail)handel & 22 & 0 & 0 & 67 & 1 & 7 & 1 & 95 \\
\hline administratie & 40 & 1 & 0 & 56 & 2 & 1 & 0 & 240 \\
\hline verzorging & 3 & 0 & 0 & 86 & 3 & 0 & 8 & 82 \\
\hline overig dienstverlening/verzorging & - & - & - & - & - & - & - & - \\
\hline overig & 25 & 0 & 0 & 75 & 0 & 0 & 0 & 80 \\
\hline \multicolumn{9}{|l|}{ MBO-tussen en -lang } \\
\hline plantenteelt & 42 & 6 & 0 & 47 & 2 & 2 & 0 & 39 \\
\hline veehouderij & 37 & 2 & 0 & 57 & 2 & 2 & 0 & 50 \\
\hline levensmiddelentechnologie & 54 & 10 & 0 & 28 & 1 & 7 & 0 & 18 \\
\hline bloemschikken & 30 & 9 & 0 & 53 & 4 & 5 & 0 & 19 \\
\hline dierenverzorging & 41 & 18 & 0 & 35 & 7 & 0 & 0 & 11 \\
\hline groene ruimte & 35 & 11 & 1 & 44 & 2 & 7 & 0 & 34 \\
\hline overig landbouw & 39 & 7 & 7 & 39 & 4 & 4 & 0 & 4 \\
\hline bouwkunde & 42 & 19 & 0 & 38 & 0 & 2 & 0 & 126 \\
\hline elektrotechniek & 53 & 9 & 0 & 37 & 0 & 0 & 0 & 251 \\
\hline werktuigbouwkunde & 55 & 16 & 1 & 26 & 0 & 1 & 0 & 167 \\
\hline weg- en waterbouwkunde & 64 & 15 & 0 & 15 & 0 & 7 & 0 & 23 \\
\hline motorvoertuigentechniek & 26 & 17 & 0 & 16 & 0 & 42 & 0 & 41 \\
\hline mechanische techniek & 31 & 24 & 0 & 45 & 0 & 0 & 0 & 5 \\
\hline grafische techniek & 44 & 37 & 2 & 15 & 0 & 1 & 0 & 21 \\
\hline proces- en laboratoriumtechniek & 69 & 20 & 0 & 6 & 3 & 1 & 0 & 77 \\
\hline nautisch & - & - & - & - & - & - & - & - \\
\hline mode \& kleding (techn) & 51 & 3 & 0 & 42 & 2 & 0 & 2 & 62 \\
\hline overig techniek & 45 & 7 & 0 & 38 & 0 & 9 & 0 & 55 \\
\hline administratie & 43 & 49 & 0 & 5 & 1 & 1 & 0 & 175 \\
\hline secretariaat & 63 & 27 & 4 & 5 & 0 & 0 & 0 & 108 \\
\hline commercieel & 70 & 28 & 0 & 1 & 0 & 0 & 0 & 99 \\
\hline economisch-juridisch & 76 & 19 & 0 & 5 & 0 & 0 & 0 & 23 \\
\hline vrije afstudeerrichting & 69 & 27 & 0 & 3 & 0 & 0 & 0 & 42 \\
\hline toerisme en recreatie & 50 & 46 & 1 & 1 & 1 & 1 & 0 & 58 \\
\hline logistiek & 54 & 37 & 0 & 1 & 2 & 4 & 1 & 9 \\
\hline (detail)handel & 55 & 7 & 0 & 34 & 3 & 1 & 0 & 260 \\
\hline horeca & 32 & 53 & 4 & 8 & 2 & 2 & 0 & 44 \\
\hline overig economie & 59 & 26 & 0 & 13 & 1 & 1 & 0 & 144 \\
\hline agogisch werk & 69 & 2 & 0 & 23 & 5 & 1 & 0 & 193 \\
\hline verzorging & 43 & 1 & 0 & 49 & 6 & 0 & 1 & 157 \\
\hline assistenten gezondheidszorg & 69 & 15 & 1 & 10 & 4 & 1 & 0 & 94 \\
\hline mode en kleding & 66 & 4 & 0 & 27 & 1 & 1 & 0 & 65 \\
\hline activiteitenbegeleiding & 61 & 8 & 2 & 18 & 3 & 3 & 6 & 47 \\
\hline facilitaire dienstverlening & 40 & 0 & 0 & 53 & 2 & 3 & 2 & 34 \\
\hline uiterlijke verzorging & 56 & 11 & 0 & 30 & 2 & 1 & 0 & 29 \\
\hline sociale arbeid & 76 & 4 & 0 & 19 & 1 & 1 & 0 & 31 \\
\hline
\end{tabular}


Tabel 4B (vervolg)

Vooropleiding van schoolverlaters per opleidingsrichting

\begin{tabular}{|c|c|c|c|c|c|c|c|c|}
\hline Opleidingsrichting & MAVO & HAVO & VWO & VBO & $\begin{array}{c}\text { MBO- } \\
\text { kort }\end{array}$ & $\begin{array}{l}\text { MBO- } \\
\text { tussen } \\
\text { en -lang }\end{array}$ & overig & $\begin{array}{c}\text { Totaal } \\
\mathrm{N}=100 \%\end{array}$ \\
\hline & $\%$ & $\%$ & $\%$ & $\%$ & $\%$ & $\%$ & $\%$ & \\
\hline verpleging & 76 & 0 & 0 & 20 & 2 & 1 & 0 & 42 \\
\hline overig dienstverlening/verzorging & - & - & - & - & - & - & - & - \\
\hline overig & 79 & 1 & 0 & 19 & 1 & 2 & 0 & 178 \\
\hline Totaal & 50 & 12 & 0 & 33 & 2 & 2 & 1 & 3586 \\
\hline
\end{tabular}


Tabel 5A

Gewenste bestemming van schoolverlaters per opleidingscluster

\begin{tabular}{|c|c|c|c|c|c|}
\hline Opleidingscluster & $\begin{array}{c}\text { werken } \\
\%\end{array}$ & $\begin{array}{l}\text { leren } \\
\%\end{array}$ & $\begin{array}{c}\text { werken en } \\
\text { leren } \\
\%\end{array}$ & $\begin{array}{c}\text { iets } \\
\text { anders } \\
\%\end{array}$ & $\begin{array}{c}\text { Totaal } \\
\mathrm{N}=100 \%\end{array}$ \\
\hline AVO & 2 & 93 & 4 & 2 & 6152 \\
\hline MAVO & 2 & 93 & 4 & 1 & 2797 \\
\hline HAVO & 1 & 93 & 4 & 2 & 1825 \\
\hline WWO & 1 & 95 & 2 & 2 & 1531 \\
\hline VBO & 8 & 61 & 30 & 2 & 2468 \\
\hline landbouw & 6 & 78 & 14 & 2 & 220 \\
\hline techniek & 7 & 43 & 48 & 2 & 1153 \\
\hline economie & 7 & 76 & 15 & 2 & 489 \\
\hline dienstverlening/verzorging & 10 & 76 & 14 & 0 & 574 \\
\hline overig & 6 & 63 & 31 & 0 & 32 \\
\hline MBO-kort & 31 & 39 & 24 & 5 & 944 \\
\hline landbouw & 56 & 18 & 20 & 6 & 19 \\
\hline techniek & 30 & 16 & 44 & 9 & 243 \\
\hline economie & 39 & 44 & 12 & 5 & 433 \\
\hline dienstverlening/verzorging & 30 & 34 & 35 & 1 & 121 \\
\hline overig & 5 & 77 & 19 & 0 & 128 \\
\hline MBO-tussen en -lang & 43 & 40 & 12 & 5 & 3120 \\
\hline landbouw & 51 & 33 & 10 & 6 & 189 \\
\hline techniek & 42 & 39 & 11 & 7 & 924 \\
\hline economie & 45 & 42 & 9 & 4 & 1036 \\
\hline dienstverlening/verzorging & 50 & 30 & 18 & 3 & 772 \\
\hline overig & 6 & 86 & 5 & 4 & 200 \\
\hline Totaal & 15 & 70 & 12 & 3 & 12685 \\
\hline
\end{tabular}

Toelichting

Vraag in de enquête: Wat wilde je vorig jaar direct na de opleiding gaan doen? 
Tabel 5B

Gewenste bestemming van schoolverlaters per opleidingsrichting

Opleidingsrichting

\begin{tabular}{ccccc} 
werken & leren & $\begin{array}{c}\text { werken en } \\
\text { leren }\end{array}$ & $\begin{array}{c}\text { iets } \\
\text { anders }\end{array}$ & $\begin{array}{c}\text { Totaal } \\
\mathrm{N}=100 \%\end{array}$ \\
$\%$ & $\%$ & $\%$ & $\%$ & \\
\hline
\end{tabular}

\section{AVO}

MAVO

HAVO

WW0

2

1

1

93

93

95

$\begin{array}{lll}4 & 1 & 2797 \\ 4 & 2 & 1825 \\ 2 & 2 & 1531\end{array}$

\section{VBO}

landbouw

bouwtechniek

mechanische techniek

elektrotechniek

motorvoertuigentechniek

consumptieve techniek

installatietechniek

grafische techniek

overig techniek

administratie

verkoop

handel

verzorging

uiterlijke verzorging

mode en kleding

overig

13

$\begin{array}{rrrr}78 & 14 & 2 & 220 \\ 23 & 63 & 1 & 228 \\ 41 & 48 & 1 & 219 \\ 65 & 27 & 4 & 260 \\ 36 & 60 & 0 & 168 \\ 38 & 52 & 5 & 168 \\ - & - & - & - \\ 77 & 16 & 0 & 43 \\ - & - & - & - \\ 79 & 14 & 2 & 272 \\ 65 & 24 & 0 & 112 \\ 82 & 9 & 2 & 104 \\ 79 & 12 & 0 & 451 \\ 56 & 26 & 0 & 51 \\ 71 & 16 & 0 & 71 \\ 63 & 31 & 0 & 32\end{array}$

MBO-kort

landbouw

elektrotechniek

motorv. techniek

consumptieve techniek

werktuigbouw

overig techniek

(detail)handel

administratie

verzorging

overig dienstverlening/verzorging

overig

MBO-tussen en -lang

plantenteelt

veehouderij

levensmiddelentechnologie

bloemschikken

dierenverzorging

groene ruimte

overig landbouw

bouwkunde

elektrotechniek

werktuigbouwkunde

weg- en waterbouwkunde

motorvoertuigentechniek

mechanische techniek

grafische techniek 
Tabel 5B (vervolg)

Gewenste bestemming van schoolverlaters per opleidingsrichting

Opleidingsrichting

$\begin{array}{ccc}\text { werken } & \text { leren } & \begin{array}{c}\text { werken en } \\ \text { leren } \\ \%\end{array} \\ \% & \%\end{array}$

iets Totaal

anders $\mathrm{N}=100 \%$

\begin{tabular}{|c|c|c|c|c|c|}
\hline & $\%$ & $\%$ & $\%$ & $\%$ & \\
\hline proces- en laboratoriumtechniek & 49 & 39 & 10 & 1 & 83 \\
\hline nautisch & - & - & - & - & - \\
\hline mode \& kleding (techn) & 45 & 40 & 5 & 9 & 65 \\
\hline overig techniek & 59 & 21 & 14 & 6 & 63 \\
\hline administratie & 33 & 56 & 8 & 3 & 183 \\
\hline secretariaat & 69 & 21 & 6 & 3 & 115 \\
\hline commercieel & 31 & 53 & 12 & 4 & 110 \\
\hline economisch-juridisch & 34 & 53 & 8 & 5 & 27 \\
\hline vrije afstudeerrichting & 36 & 45 & 17 & 2 & 47 \\
\hline toerisme en recreatie & 59 & 31 & 5 & 4 & 61 \\
\hline logistiek & 38 & 53 & 3 & 6 & 9 \\
\hline (detail)handel & 46 & 37 & 11 & 7 & 278 \\
\hline horeca & 53 & 28 & 13 & 6 & 53 \\
\hline overig economie & 42 & 48 & 7 & 3 & 153 \\
\hline agogisch werk & 44 & 38 & 14 & 4 & 212 \\
\hline verzorging & 59 & 11 & 28 & 1 & 166 \\
\hline assistenten gezondheidszorg & 70 & 19 & 12 & 0 & 102 \\
\hline mode en kleding & 44 & 39 & 13 & 4 & 69 \\
\hline activiteitenbegeleiding & 62 & 28 & 8 & 2 & 51 \\
\hline facilitaire dienstverlening & 40 & 34 & 24 & 3 & 36 \\
\hline uiterlijke verzorging & 62 & 16 & 18 & 4 & 33 \\
\hline sociale arbeid & 28 & 59 & 8 & 5 & 34 \\
\hline verpleging & 21 & 44 & 32 & 3 & 47 \\
\hline overig dienstverlening/verzorging & - & - & - & - & - \\
\hline overig & 6 & 86 & 5 & 4 & 200 \\
\hline Totaal & 15 & 70 & 12 & 3 & 12685 \\
\hline
\end{tabular}

- = geen gegevens vanwege kleine aantallen

Toelichting

Vraag in de enquête: Wat wilde je vorig jaar direct na de opleiding gaan doen? 
Tabel 6A

Bestemming van schoolverlaters per opleidingscluster

\begin{tabular}{|c|c|c|c|c|c|c|c|}
\hline Opleidingscluster & $\begin{array}{c}\text { studie } \\
\%\end{array}$ & $\begin{array}{c}\text { LLW/ } \\
\text { in-serv } \\
\%\end{array}$ & $\begin{array}{c}\text { betaald } \\
\text { werk } \\
\%\end{array}$ & $\begin{array}{c}\text { werk- } \\
\text { loos } \\
\%\end{array}$ & $\begin{array}{c}\text { milit. } \\
\text { dienst } \\
\%\end{array}$ & $\begin{array}{c}\text { anders } \\
\qquad \%\end{array}$ & $\begin{array}{c}\text { Totaal } \\
N=100 \%\end{array}$ \\
\hline AVO & 92 & 2 & 4 & 1 & 0 & 1 & 6179 \\
\hline MAVO & 92 & 3 & 4 & 0 & 0 & 1 & 2813 \\
\hline HAVO & 91 & 2 & 4 & 2 & 0 & 1 & 1827 \\
\hline WW0 & 94 & 0 & 4 & 0 & 0 & 1 & 1538 \\
\hline VBO & 59 & 27 & 12 & 2 & 0 & 1 & 2530 \\
\hline landbouw & 77 & 13 & 8 & 1 & 0 & 1 & 224 \\
\hline techniek & 43 & 42 & 12 & 2 & 0 & 1 & 1189 \\
\hline economie & 74 & 12 & 11 & 2 & 0 & 1 & 505 \\
\hline dienstverlening/verzorging & 72 & 13 & 13 & 2 & 0 & 1 & 581 \\
\hline overig & 66 & 25 & 3 & 3 & 3 & 0 & 32 \\
\hline MBO-kort & 36 & 16 & 36 & 8 & 3 & 2 & 957 \\
\hline landbouw & 18 & 9 & 58 & 6 & 6 & 3 & 19 \\
\hline techniek & 14 & 34 & 38 & 7 & 7 & 0 & 245 \\
\hline economie & 40 & 5 & 42 & 9 & 2 & 2 & 441 \\
\hline dienstverlening/verzorging & 29 & 23 & 31 & 14 & 0 & 3 & 124 \\
\hline overig & 71 & 14 & 9 & 3 & 1 & 2 & 128 \\
\hline MBO-tussen en -lang & 38 & 4 & 48 & 4 & 4 & 1 & 3136 \\
\hline landbouw & 30 & 4 & 58 & 2 & 4 & 1 & 190 \\
\hline techniek & 37 & 3 & 45 & 4 & 10 & 0 & 929 \\
\hline economie & 39 & 1 & 52 & 5 & 3 & 1 & 1042 \\
\hline dienstverlening/verzorging & 27 & 11 & 55 & 5 & 0 & 2 & 776 \\
\hline overig & 85 & 1 & 9 & 3 & 2 & 1 & 200 \\
\hline Totaal & 68 & 9 & 19 & 2 & 1 & 1 & 12803 \\
\hline
\end{tabular}

\section{Toelichting}

Vragen in de enquête:

- Wat doe je op dit moment? Geef je voornaamste bezigheid aan.

- Volg je op dit moment een opleiding in het leerlingwezen of een in-service opleiding in de verpleging of verzorging? 
Tabel 6B

Bestemming van schoolverlaters per opleidingsrichting

\begin{tabular}{|c|c|c|c|c|c|c|c|}
\hline Opleidingscluster & $\begin{array}{c}\text { studie } \\
\%\end{array}$ & $\begin{array}{c}\text { LLW/ } \\
\text { in-serv } \\
\%\end{array}$ & $\begin{array}{c}\text { betaald } \\
\text { werk } \\
\%\end{array}$ & $\begin{array}{c}\text { werk- } \\
\text { loos } \\
\%\end{array}$ & $\begin{array}{c}\text { milit. } \\
\text { dienst } \\
\%\end{array}$ & $\begin{array}{c}\text { anders } \\
\%\end{array}$ & $\begin{array}{c}\text { Totaal } \\
N=100 \%\end{array}$ \\
\hline \multicolumn{8}{|l|}{ AVO } \\
\hline MAVO & 92 & 3 & 4 & 0 & 0 & 1 & 2813 \\
\hline HAVO & 91 & 2 & 4 & 2 & 0 & 1 & 1827 \\
\hline WWO & 94 & 0 & 4 & 0 & 0 & 1 & 1538 \\
\hline \multicolumn{8}{|l|}{ VBO } \\
\hline landbouw & 77 & 13 & 8 & 1 & 0 & 1 & 224 \\
\hline bouwtechniek & 24 & 60 & 14 & 2 & 0 & 0 & 235 \\
\hline mechanische techniek & 40 & 42 & 14 & 3 & 1 & 0 & 225 \\
\hline elektrotechniek & 63 & 24 & 10 & 1 & 0 & 1 & 274 \\
\hline motorvoertuigentechniek & 33 & 56 & 11 & 0 & 0 & 0 & 168 \\
\hline consumptieve techniek & 40 & 40 & 13 & 5 & 0 & 2 & 174 \\
\hline installatietechniek & - & - & - & - & - & - & - \\
\hline grafische techniek & 63 & 10 & 16 & 10 & 0 & 2 & 44 \\
\hline overig techniek & - & - & - & - & - & - & - \\
\hline administratie & 79 & 11 & 8 & 1 & 0 & 0 & 281 \\
\hline verkoop & 57 & 21 & 16 & 5 & 0 & 1 & 117 \\
\hline handel & 77 & 4 & 13 & 1 & 2 & 2 & 107 \\
\hline verzorging & 74 & 12 & 11 & 1 & 0 & 2 & 456 \\
\hline uiterlijke verzorging & 53 & 24 & 21 & 3 & 0 & 0 & 51 \\
\hline mode en kleding & 69 & 9 & 20 & 2 & 0 & 0 & 74 \\
\hline overig & 66 & 25 & 3 & 3 & 3 & 0 & 32 \\
\hline \multicolumn{8}{|l|}{ MBO-kort } \\
\hline landbouw & 18 & 9 & 58 & 6 & 6 & 3 & 19 \\
\hline elektrotechniek & 14 & 26 & 43 & 8 & 9 & 0 & 30 \\
\hline motorv. techniek & 11 & 54 & 26 & 3 & 6 & 0 & 53 \\
\hline consumptieve techniek & 13 & 37 & 40 & 5 & 4 & 1 & 65 \\
\hline werktuigbouw & 20 & 22 & 42 & 5 & 10 & 0 & 51 \\
\hline overig techniek & 9 & 24 & 43 & 17 & 7 & 0 & 46 \\
\hline (detail)handel & 39 & 5 & 44 & 10 & 0 & 3 & 157 \\
\hline administratie & 41 & 6 & 41 & 8 & 3 & 2 & 284 \\
\hline verzorging & 34 & 20 & 31 & 12 & 0 & 3 & 101 \\
\hline overig dienstverlening/verzorging & - & - & - & - & - & - & - \\
\hline overig & 71 & 14 & 9 & 3 & 1 & 2 & 128 \\
\hline \multicolumn{8}{|l|}{ MBO-tussen en -lang } \\
\hline plantenteelt & 30 & 2 & 62 & 1 & 3 & 2 & 43 \\
\hline veehouderij & 30 & 5 & 60 & 2 & 2 & 1 & 54 \\
\hline levensmiddelentechnologie & 36 & 2 & 48 & 6 & 8 & 0 & 20 \\
\hline bloemschikken & 13 & 6 & 77 & 2 & 2 & 1 & 19 \\
\hline dierenverzorging & 26 & 0 & 61 & 8 & 1 & 4 & 12 \\
\hline groene ruimte & 38 & 6 & 47 & 1 & 7 & 0 & 37 \\
\hline overig landbouw & 23 & 3 & 63 & 7 & 0 & 3 & 5 \\
\hline bouwkunde & 45 & 2 & 41 & 5 & 6 & 1 & 144 \\
\hline elektrotechniek & 41 & 2 & 39 & 6 & 13 & 0 & 283 \\
\hline werktuigbouwkunde & 38 & 4 & 43 & 2 & 13 & 0 & 191 \\
\hline weg- en waterbouwkunde & 16 & 8 & 45 & 2 & 28 & 0 & 26 \\
\hline motorvoertuigentechniek & 40 & 11 & 46 & 0 & 2 & 0 & 43 \\
\hline mechanische techniek & 39 & 7 & 48 & 0 & 7 & 0 & 6 \\
\hline grafische techniek & 22 & 1 & 67 & 5 & 4 & 1 & 23 \\
\hline
\end{tabular}


Tabel 6B (vervolg)

Bestemming van schoolverlaters per opleidingsrichting

\begin{tabular}{|c|c|c|c|c|c|c|c|}
\hline Opleidingscluster & $\begin{array}{c}\text { studie } \\
\%\end{array}$ & $\begin{array}{c}\text { LLW/ } \\
\text { in-serv } \\
\%\end{array}$ & $\begin{array}{c}\text { betaald } \\
\text { werk } \\
\%\end{array}$ & $\begin{array}{c}\text { werk- } \\
\text { loos } \\
\%\end{array}$ & $\begin{array}{c}\text { milit. } \\
\text { dienst } \\
\%\end{array}$ & $\begin{array}{c}\text { anders } \\
\%\end{array}$ & $\begin{array}{c}\text { Totaal } \\
N=100 \%\end{array}$ \\
\hline proces- en laboratoriumtechniek & 37 & 1 & 47 & 2 & 13 & 0 & 83 \\
\hline nautisch & - & - & - & - & - & - & - \\
\hline mode \& kleding (techn) & 38 & 0 & 54 & 8 & 0 & 0 & 65 \\
\hline overig techniek & 19 & 8 & 61 & 3 & 8 & 2 & 64 \\
\hline administratie & 57 & 1 & 36 & 3 & 3 & 1 & 183 \\
\hline secretariaat & 18 & 1 & 76 & 4 & 0 & 1 & 116 \\
\hline commercieel & 48 & 1 & 42 & 4 & 5 & 0 & 110 \\
\hline economisch-juridisch & 39 & 0 & 44 & 8 & 1 & 8 & 27 \\
\hline vrije afstudeerrichting & 41 & 0 & 46 & 8 & 2 & 2 & 48 \\
\hline toerisme en recreatie & 30 & 0 & 65 & 4 & 1 & 1 & 61 \\
\hline logistiek & 49 & 1 & 37 & 5 & 8 & 0 & 9 \\
\hline (detail)handel & 32 & 2 & 54 & 6 & 5 & 1 & 280 \\
\hline horeca & 26 & 1 & 68 & 1 & 3 & 0 & 54 \\
\hline overig economie & 46 & 0 & 48 & 5 & 1 & 1 & 153 \\
\hline agogisch werk & 35 & 10 & 47 & 6 & 0 & 3 & 213 \\
\hline verzorging & 11 & 24 & 60 & 4 & 0 & 1 & 166 \\
\hline assistenten gezondheidszorg & 14 & 4 & 76 & 6 & 0 & 1 & 104 \\
\hline mode en kleding & 36 & 1 & 55 & 7 & 0 & 0 & 69 \\
\hline activiteitenbegeleiding & 28 & 4 & 59 & 4 & 0 & 6 & 51 \\
\hline facilitaire dienstverlening & 29 & 12 & 49 & 6 & 5 & 0 & 36 \\
\hline uiterlijke verzorging & 16 & 3 & 73 & 4 & 0 & 3 & 33 \\
\hline sociale arbeid & 51 & 0 & 42 & 3 & 0 & 4 & 35 \\
\hline verpleging & 46 & 20 & 33 & 1 & 0 & 0 & 47 \\
\hline overig dienstverlening/verzorging & - & - & - & - & - & - & - \\
\hline overig & 85 & 1 & 9 & 3 & 2 & 1 & 200 \\
\hline Totaal & 68 & 9 & 19 & 2 & 1 & 1 & 12803 \\
\hline
\end{tabular}

- = geen gegevens vanwege kleine aantallen

\section{Toelichting}

Vragen in de enquête:

-Wat doe je op dit moment? Geef je voornaamste bezigheid aan.

- Volg je op dit moment een opleiding in het leerlingwezen of een in-service opleiding in de verpleging of verzorging? 
Tabel 6C

Bestemming van schoolverlaters, verbijzonderd naar regio per opleidingscluster

\begin{tabular}{|c|c|c|c|c|c|c|c|}
\hline Opleidingscluster & $\begin{array}{c}\text { studie } \\
\%\end{array}$ & $\begin{array}{c}\text { LLW/ } \\
\text { in-serv } \\
\%\end{array}$ & $\begin{array}{c}\text { betaald } \\
\text { werk } \\
\%\end{array}$ & $\begin{array}{c}\text { werk- } \\
\text { loos } \\
\%\end{array}$ & $\begin{array}{c}\text { milit. } \\
\text { dienst } \\
\%\end{array}$ & $\begin{array}{c}\text { anders } \\
\%\end{array}$ & $\begin{array}{c}\text { Totaal } \\
N=100 \%\end{array}$ \\
\hline
\end{tabular}

\section{Noord}

AVO

MAVO

HAVO

WWO

VBO

landbouw

techniek

economie

dienstverlening/verzorging

overig

MBO-kort
landbouw
techniek
economie
dienstverlening/verzorging
overig

36

54

940

\section{2}

242

96

123

MBO-tussen en -lang landbouw

40

techniek

economie

dienstverlening/verzorging

overig

Totaal Noord

1
-
0

$\begin{array}{rrr}0 & 3 & 242 \\ - & - & - \\ 0 & 0 & 123 \\ - & - & -\end{array}$

Oost

AVO

MAVO

HAVO

WWO

VBO

landbouw

techniek

economie

\section{4}

2

$\begin{array}{rrr}1 & 2 & 146 \\ 0 & 0 & 43 \\ 0 & 3 & 73 \\ - & - & - \\ - & - & - \\ - & - & -\end{array}$

dienstverlening/verzorging overig

MBO-kort
landbouw
techniek
economie
dienstverlening/verzorging
overig

$\begin{array}{rrrrrrr}61 & 23 & 16 & 0 & 0 & 1 & 310 \\ 86 & 5 & 6 & 0 & 0 & 3 & 51 \\ 37 & 41 & 22 & 0 & 0 & 1 & 141 \\ 78 & 8 & 13 & 0 & 1 & 0 & 109 \\ - & - & - & - & - & - & - \\ - & - & - & - & - & - & -\end{array}$


Tabel 6C (vervolg)

Bestemming van schoolverlaters, verbijzonderd naar regio per opleidingscluster

\begin{tabular}{|c|c|c|c|c|c|c|c|}
\hline Opleidingscluster & $\begin{array}{c}\text { studie } \\
\%\end{array}$ & $\begin{array}{c}\text { LLW/ } \\
\text { in-sery } \\
\%\end{array}$ & $\begin{array}{c}\text { betaald } \\
\text { werk } \\
\%\end{array}$ & $\begin{array}{c}\text { werk- } \\
\text { loos } \\
\%\end{array}$ & $\begin{array}{c}\text { milit. } \\
\text { dienst } \\
\%\end{array}$ & $\begin{array}{c}\text { anders } \\
\%\end{array}$ & $\begin{array}{c}\text { Totaal } \\
N=100 \%\end{array}$ \\
\hline MBO-tussen en -lang & 38 & 6 & 48 & 4 & 2 & 1 & 531 \\
\hline landbouw & 30 & 4 & 59 & 3 & 3 & 1 & 70 \\
\hline techniek & 43 & 0 & 49 & 8 & 0 & 0 & 49 \\
\hline economie & 43 & 1 & 48 & 2 & 6 & 0 & 109 \\
\hline dienstverlening/verzorging & 26 & 12 & 56 & 4 & 0 & 2 & 242 \\
\hline overig & 85 & 0 & 8 & 3 & 2 & 2 & 60 \\
\hline Totaal Oost & 78 & 6 & 14 & 1 & 0 & 1 & 2765 \\
\hline \multicolumn{8}{|l|}{ West } \\
\hline AVO & 89 & 3 & 6 & 1 & 0 & 1 & 2688 \\
\hline MAVO & 89 & 5 & 4 & 0 & 0 & 1 & 1185 \\
\hline HAVO & 88 & 2 & 6 & 2 & 0 & 1 & 806 \\
\hline WWO & 91 & 0 & 7 & 0 & 0 & 1 & 697 \\
\hline VBO & 57 & 26 & 14 & 2 & 0 & 1 & 1258 \\
\hline landbouw & 69 & 17 & 10 & 2 & 1 & 1 & 81 \\
\hline techniek & 47 & 37 & 13 & 2 & 0 & 1 & 653 \\
\hline economie & 72 & 12 & 13 & 1 & 0 & 1 & 284 \\
\hline dienstverlening/verzorging & 63 & 15 & 19 & 2 & 0 & 1 & 228 \\
\hline overig & - & - & - & - & - & - & - \\
\hline MBO-kort & 37 & 17 & 34 & 8 & 2 & 2 & 571 \\
\hline landbouw & 19 & 2 & 67 & 2 & 7 & 2 & 8 \\
\hline techniek & 16 & 36 & 33 & 9 & 5 & 0 & 151 \\
\hline economie & 41 & 5 & 42 & 9 & 1 & 2 & 266 \\
\hline dienstverlening/verzorging & 19 & 23 & 34 & 19 & 0 & 5 & 49 \\
\hline overig & 67 & 16 & 10 & 3 & 1 & 2 & 97 \\
\hline MBO-tussen en -lang & 38 & 3 & 50 & 4 & 4 & 1 & 1356 \\
\hline landbouw & 27 & 3 & 61 & 2 & 5 & 1 & 50 \\
\hline techniek & 33 & 3 & 51 & 3 & 9 & 0 & 404 \\
\hline economie & 40 & 1 & 52 & 4 & 3 & 1 & 521 \\
\hline dienstverlening/verzorging & 27 & 7 & 60 & 4 & 0 & 2 & 273 \\
\hline overig & 83 & 1 & 10 & 4 & 2 & 0 & 109 \\
\hline Totaal West & 66 & 9 & 20 & 3 & 1 & 1 & 5874 \\
\hline
\end{tabular}

Zuid

AVO

MAVO

HAVO

VWO

$94+\frac{1}{2}$

$92-2$

97

VBO

landbouw

techniek

economie

dienstverlening/verzorging

61

overig

$\begin{array}{ll}78 & 17 \\ 39 & 52 \\ 73 & 18 \\ 77 & 11\end{array}$


Tabel 6C (vervolg)

Bestemming van schoolverlaters, verbijzonderd naar regio per opleidingscluster

\begin{tabular}{|c|c|c|c|c|c|c|c|}
\hline Opleidingscluster & $\begin{array}{c}\text { studie } \\
\%\end{array}$ & $\begin{array}{c}\text { LLW/ } \\
\text { in-serv } \\
\%\end{array}$ & $\begin{array}{c}\text { betaald } \\
\text { werk } \\
\%\end{array}$ & $\begin{array}{c}\text { werk- } \\
\text { loos } \\
\%\end{array}$ & $\begin{array}{c}\text { milit. } \\
\text { dienst } \\
\%\end{array}$ & $\begin{array}{c}\text { anders } \\
\%\end{array}$ & $\begin{array}{c}\text { Totaal } \\
N=100 \%\end{array}$ \\
\hline MBO-kort & 36 & 14 & 37 & 8 & 4 & 2 & 203 \\
\hline landbouw & 16 & 20 & 52 & 4 & 4 & 4 & 4 \\
\hline techniek & 11 & 26 & 48 & 4 & 11 & 1 & 56 \\
\hline economie & 32 & 0 & 50 & 11 & 2 & 5 & 70 \\
\hline dienstverlening/verzorging & 42 & 25 & 21 & 12 & 0 & 0 & 41 \\
\hline overig & 84 & 6 & 6 & 3 & 0 & 0 & 31 \\
\hline MBO-tussen en -lang & 37 & 3 & 47 & 5 & 7 & 1 & 944 \\
\hline landbouw & 26 & 5 & 62 & 3 & 3 & 1 & 37 \\
\hline techniek & 41 & 3 & 39 & 4 & 12 & 0 & 475 \\
\hline economie & 34 & 0 & 56 & 6 & 2 & 2 & 272 \\
\hline dienstverlening/verzorging & 23 & 9 & 58 & 6 & 1 & 2 & 139 \\
\hline overig & - & - & - & - & - & - & - \\
\hline Totaal Zuid & 66 & 9 & 19 & 3 & 2 & 1 & 3340 \\
\hline
\end{tabular}

\section{Toelichting}

Vragen in de enquête:

-Wat doe je op dit moment? Geef je voornaamste bezigheid aan.

- Volg je op dit moment een opleiding in het leerlingwezen of een in-service opleiding in de verpleging of verzorging? 
Tabel 6D

Bestemming van schoolverlaters, verbijzonderd naar vooropleiding per opleidingscluster

\begin{tabular}{cccccccc} 
Opleidingscluster & studie & $\begin{array}{c}\text { LLW/ } \\
\text { in-serv } \\
\%\end{array}$ & $\begin{array}{c}\text { betaald } \\
\text { werk } \\
\%\end{array}$ & $\begin{array}{c}\text { werk- } \\
\text { loos } \\
\%\end{array}$ & $\begin{array}{c}\text { milit. } \\
\text { dienst } \\
\%\end{array}$ & $\begin{array}{c}\text { anders } \\
\text { Totaal }\end{array}$ & $\begin{array}{c}\mathrm{N}=100 \% \\
0\end{array}$ \\
\hline
\end{tabular}

Vooropleiding MAVO

\begin{tabular}{|c|c|c|c|c|c|c|c|}
\hline MBO-kort & 37 & 13 & 41 & 6 & 3 & 0 & 201 \\
\hline landbouw & - & - & - & - & - & - & - \\
\hline techniek & 13 & 40 & 34 & 4 & 9 & 0 & 56 \\
\hline economie & 40 & 2 & 49 & 8 & 1 & 0 & 118 \\
\hline dienstverlening/verzorging & - & - & - & - & - & - & - \\
\hline overig & - & - & - & - & - & - & - \\
\hline MBO-tussen en -lang & 42 & 4 & 46 & 3 & 4 & 1 & 1602 \\
\hline landbouw & 39 & 4 & 51 & 2 & 2 & 2 & 68 \\
\hline techniek & 42 & 3 & 41 & 3 & 11 & 0 & 425 \\
\hline economie & 37 & 1 & 53 & 4 & 3 & 1 & 536 \\
\hline dienstverlening/verzorging & 33 & 10 & 51 & 4 & 0 & 2 & 432 \\
\hline overig & 85 & 1 & 9 & 2 & 1 & 1 & 140 \\
\hline Totaal vooropleiding MAVO & 41 & 5 & 45 & 4 & 4 & 1 & 1802 \\
\hline
\end{tabular}

Vooropleiding HAVO

MBO-tussen en -lang

landbouw

techniek

economie

dienstverlening/verzorging

overig

Totaal vooropleiding HAVO

Vooropleiding VWO

MBO-tussen en -lang
landbouw
techniek
economie
dienstverlening/verzorging
overig

Totaal vooropleiding VWO

Vooropleiding VBO
10

10
0

$\begin{array}{rrr}34 & 19 & 36 \\ 18 & 10 & 60 \\ 14 & 34 & 40 \\ 39 & 8 & 41 \\ 34 & 22 & 30 \\ 62 & 18 & 15\end{array}$

85

85

2
4
2
3
1
-

428

economie

dienstverlening/verzorging overig

36
60
40
41
30
15

6
5
6
5
11
2

3
7
6
3


Tabel 6D (vervolg)

Bestemming van schoolverlaters, verbijzonderd naar vooropleiding per opleidingscluster

\begin{tabular}{lccccccr} 
Opleidingscluster & studie & $\begin{array}{c}\text { LLW/ } \\
\text { in-serv } \\
\%\end{array}$ & $\begin{array}{c}\text { betaald } \\
\text { werk } \\
\%\end{array}$ & $\begin{array}{c}\text { werk- } \\
\text { loos } \\
\%\end{array}$ & $\begin{array}{c}\text { milit. } \\
\text { dienst } \\
\%\end{array}$ & anders & $\begin{array}{c}\text { Totaal } \\
\mathbf{N}=100 \%\end{array}$ \\
\hline $\begin{array}{l}\text { MBO-tussen en -lang } \\
\text { landbouw }\end{array}$ & 27 & 7 & 53 & 6 & 7 & 1 & 703 \\
techniek & 21 & 6 & 64 & 3 & 5 & 1 & 82 \\
economie & 28 & 5 & 47 & 5 & 15 & 0 & 253 \\
dienstverlening/verzorging & 25 & 1 & 60 & 9 & 3 & 2 & 129 \\
overig & 20 & 15 & 58 & 6 & 0 & 1 & 206 \\
Totaal vooropleiding VBO & 76 & 0 & 12 & 9 & 3 & 0 & 33 \\
& 29 & 12 & 46 & 6 & 5 & 1 & 1185
\end{tabular}

Vooropleiding MBO-kort

$\begin{array}{lrrrrrrr}\text { MBO-tussen en -lang } & 14 & 6 & 67 & 6 & 4 & 3 & 51 \\ \text { landbouw } & 4 & 0 & 93 & 0 & 4 & 0 & 4 \\ \text { techniek } & - & - & - & - & - & - & - \\ \text { economie } & 14 & 0 & 70 & 14 & 2 & 0 & 14 \\ \text { dienstverlening/verzorging } & 14 & 12 & 62 & 3 & 3 & 6 & 27 \\ \text { overig } & - & - & - & - & - & - & - \\ \text { Totaal vooropleiding MBO-kort } & 16 & 11 & 59 & 6 & 3 & 5 & 68\end{array}$

Vooropleiding MBO-tussen en -lang

$\begin{array}{lrrrrrrr}\text { MBO-tussen en -lang } & 22 & 1 & 70 & 3 & 2 & 0 & 54 \\ \text { landbouw } & 11 & 0 & 84 & 2 & 2 & 0 & 7 \\ \text { techniek } & 27 & 1 & 69 & 0 & 4 & 0 & 30 \\ \text { economie } & - & - & - & - & - & - & - \\ \text { dienstverlening/verzorging } & - & - & - & - & - & - & - \\ \text { overig } & - & - & - & - & - & - & - \\ \begin{array}{l}\text { Totaal vooropleiding MB0- } \\ \text { tussen en -lang }\end{array} & & & & & & \\ -\end{array}$

\section{Toelichting}

Vragen in de enquête:

- Wat doe je op dit moment? Geef je voornaamste bezigheid aan.

- Volg je op dit moment een opleiding in het leerlingwezen of een in-service opleiding in de verpleging of verzorging? 
Kerngegevens / Schoolverlaters tussen onderwijs en arbeidsmarkt 1995 
Kerngegevens / Schoolverlaters tussen onderwijs en arbeidsmarkt 1995

2 Doorstroom naar vervolgonderwijs 
Kerngegevens / Schoolverlaters tussen onderwijs en arbeidsmarkt 1995 
Tabel 7A

Vervolgopleiding van verder lerende schoolverlaters per opleidingscluster

\begin{tabular}{|c|c|c|c|c|c|c|c|c|c|c|}
\hline \multirow[t]{2}{*}{ Opleidingscluster } & \multirow{2}{*}{$\begin{array}{c}\text { MAVO } \\
\quad \%\end{array}$} & \multicolumn{2}{|c|}{ HAVO VWO } & VBO & \multicolumn{2}{|c|}{$\begin{array}{l}\text { MBO- MBO- } \\
\text { kort tussen } \\
\text { en -lang }\end{array}$} & HBO & wo & overig & \multirow[t]{2}{*}{$\begin{array}{l}\text { Totaal } \\
\mathrm{N}=100 \%\end{array}$} \\
\hline & & $\%$ & $\%$ & $\%$ & $\%$ & $\%$ & $\%$ & $\%$ & $\%$ & \\
\hline AVO & 0 & 9 & 4 & 0 & 3 & 41 & 26 & 15 & 2 & 5589 \\
\hline MAVO & 0 & 18 & 0 & 0 & 3 & 77 & 0 & 0 & 1 & 2532 \\
\hline HAVO & 0 & 2 & 11 & 0 & 4 & 21 & 59 & 0 & 3 & 1633 \\
\hline vw0 & 0 & 0 & 3 & 0 & 0 & 1 & 34 & 60 & 2 & 1423 \\
\hline VBO & 1 & 0 & 0 & 2 & 27 & 69 & 0 & 0 & 1 & 1455 \\
\hline landbouw & 0 & 0 & 0 & 1 & 9 & 89 & 0 & 0 & 0 & 167 \\
\hline techniek & 2 & 0 & 0 & 4 & 32 & 61 & 0 & 0 & 2 & 487 \\
\hline economie & 3 & 0 & 0 & 1 & 33 & 63 & 0 & 0 & 0 & 367 \\
\hline dienstverlening/verzorging & 0 & 0 & 0 & 1 & 23 & 76 & 0 & 0 & 0 & 415 \\
\hline overig & - & - & - & - & - & - & - & - & - & - \\
\hline MBO-kort & 2 & 2 & 0 & 0 & 12 & 79 & 0 & 0 & 5 & 327 \\
\hline landbouw & - & - & - & - & - & - & - & - & - & - \\
\hline techniek & 0 & 5 & 0 & 3 & 20 & 61 & 0 & 0 & 10 & 30 \\
\hline economie & 2 & 2 & 0 & 0 & 8 & 81 & 0 & 0 & 7 & 168 \\
\hline dienstverlening/verzorging & 0 & 0 & 0 & 0 & 12 & 82 & 0 & 0 & 5 & 36 \\
\hline overig & 3 & 0 & 0 & 0 & 18 & 78 & 0 & 0 & 1 & 90 \\
\hline MBO-tussen en -lang & 0 & 1 & 0 & 0 & 2 & 11 & 78 & 0 & 7 & 1183 \\
\hline landbouw & 0 & 1 & 0 & 0 & 4 & 21 & 72 & 0 & 2 & 56 \\
\hline techniek & 0 & 0 & 0 & 0 & 2 & 14 & 82 & 0 & 2 & 347 \\
\hline economie & 0 & 0 & 0 & 0 & 3 & 7 & 75 & 0 & 15 & 401 \\
\hline dienstverlening/verzorging & 0 & 1 & 0 & 0 & 1 & 9 & 86 & 0 & 4 & 211 \\
\hline overig & 0 & 3 & 1 & 0 & 3 & 16 & 71 & 0 & 6 & 168 \\
\hline Totaal & 0 & 6 & 3 & 0 & 7 & 43 & 28 & 10 & 2 & 8553 \\
\hline
\end{tabular}

Toelichting

Het gaat hier alleen om de doorstroom naar reguliere voltijdse vervolgopleidingen. Voor de doorstroom naar het leerlingwezen of in-service onderwijs wordt verwezen naar tabel 10. 
Tabel 7B

Vervolgopleiding van verder lerende schoolverlaters per opleidingsrichting

Opleidingsrichting

\begin{tabular}{|c|c|c|c|c|c|c|c|c|}
\hline MAVC & $A V$ & /WO & VBO & $\begin{array}{r}\text { MBO } \\
\text { kort }\end{array}$ & $\begin{array}{l}\text { MBO- } \\
\text { tussen } \\
\text { en -lang }\end{array}$ & HBO & wo & $\begin{array}{l}\text { overig Totaal } \\
\qquad N=100 \%\end{array}$ \\
\hline$\%$ & $\%$ & $\%$ & $\%$ & $\%$ & $\%$ & $\%$ & $\%$ & $\%$ \\
\hline
\end{tabular}

AVO

MAVO

HAVO

VWO

$\begin{array}{rrrrrrrrrr}0 & 18 & 0 & 0 & 3 & 77 & 0 & 0 & 1 & 2532 \\ 0 & 2 & 11 & 0 & 4 & 21 & 59 & 0 & 3 & 1633 \\ 0 & 0 & 3 & 0 & 0 & 1 & 34 & 60 & 2 & 1423\end{array}$

VBO

landbouw

bouwtechniek

mechanische techniek

elektrotechniek

motorvoertuigentechniek

consumptieve techniek

installatietechniek

grafische techniek

overig techniek

administratie

verkoop

handel

verzorging

uiterlijke verzorging

mode en kleding

overig

MBO-kort

landbouw

elektrotechniek

motorv. techniek

consumptieve techniek

werktuigbouw

overig techniek

(detail)handel

administratie

verzorging

overig dienstverlening/verzorging

overig

$\begin{array}{llll}0 & 0 & 0 & 1 \\ 0 & 0 & 0 & 2 \\ 0 & 0 & 0 & 7 \\ 5 & 0 & 0 & 5 \\ - & - & - & - \\ 0 & 0 & 0 & 0 \\ - & - & - & - \\ 0 & 0 & 0 & 8 \\ - & - & - & - \\ 3 & 0 & 0 & 1 \\ 7 & 0 & 0 & 0 \\ 0 & 0 & 0 & 1 \\ 0 & 0 & 0 & 0 \\ - & - & - & - \\ 0 & 0 & 0 & 5 \\ - & - & - & -\end{array}$

$\begin{array}{rrrrrr}9 & 89 & 0 & 0 & 0 & 167 \\ 30 & 58 & 0 & 0 & 10 & 55 \\ 41 & 48 & 0 & 0 & 3 & 85 \\ 19 & 69 & 0 & 0 & 2 & 173 \\ - & - & - & - & - & - \\ 51 & 49 & 0 & 0 & 0 & 62 \\ - & - & - & - & - & - \\ 44 & 47 & 0 & 0 & 0 & 25 \\ - & - & - & - & - & - \\ 38 & 58 & 0 & 0 & 0 & 220 \\ 42 & 51 & 0 & 0 & 0 & 67 \\ 10 & 87 & 0 & 0 & 1 & 80 \\ 20 & 80 & 0 & 0 & 0 & 337 \\ - & - & - & - & - & - \\ 36 & 59 & 0 & 0 & 0 & 51 \\ - & - & - & - & - & -\end{array}$

MBO-tussen en -lang

plantenteelt

veehouderij

levensmiddelentechnologie

bloemschikken

dierenverzorging

groene ruimte

overig landbouw

bouwkunde

elektrotechniek

werktuigbouwkunde

weg- en waterbouwkunde motorvoertuigentechniek mechanische techniek

$\begin{array}{rrrrrrrrrr}0 & 0 & 0 & 1 & 3 & 22 & 70 & 0 & 4 & 13 \\ 0 & 1 & 0 & 0 & 6 & 23 & 69 & 0 & 1 & 16 \\ 0 & 0 & 0 & 0 & 5 & 22 & 72 & 0 & 2 & 7 \\ - & - & - & - & - & - & - & - & - & - \\ - & - & - & - & - & - & - & - & - & - \\ 0 & 1 & 0 & 0 & 1 & 20 & 78 & 0 & 0 & 14 \\ - & - & - & - & - & - & - & - & - & - \\ 0 & 0 & 0 & 0 & 1 & 18 & 81 & 0 & 0 & 64 \\ 0 & 0 & 0 & 0 & 2 & 10 & 88 & 0 & 0 & 115 \\ 0 & 0 & 0 & 0 & 3 & 7 & 88 & 0 & 1 & 72 \\ - & - & - & - & - & - & - & - & - & - \\ 0 & 0 & 0 & 0 & 13 & 19 & 67 & 0 & 1 & 17 \\ - & - & - & - & - & - & - & - & - & -\end{array}$


Tabel 7B (vervolg)

Vervolgopleiding van verder lerende schoolverlaters per opleidingsrichting

Opleidingsrichting

MAVO HAVO VWO VBO MBO- MBO- HBO WO overig Totaal

kort tussen

$\mathrm{N}=100 \%$

en -lang

\begin{tabular}{lrrrrrrrrrr} 
& $\%$ & $\%$ & $\%$ & $\%$ & $\%$ & $\%$ & $\%$ & $\%$ & $\%$ & \\
\hline grafische techniek & 0 & 0 & 0 & 0 & 0 & 23 & 73 & 0 & 4 & 5 \\
proces- en laboratoriumtechniek & 0 & 1 & 1 & 0 & 0 & 11 & 88 & 0 & 0 & 31 \\
mode \& kleding (techn) & 0 & 1 & 0 & 0 & 0 & 35 & 57 & 0 & 7 & 25 \\
overig techniek & - & - & - & - & - & - & - & - & - & - \\
administratie & 0 & 0 & 1 & 0 & 1 & 4 & 83 & 0 & 12 & 103 \\
secretariaat & 0 & 0 & 0 & 0 & 2 & 15 & 57 & 0 & 26 & 22 \\
commercieel & 0 & 0 & 0 & 0 & 4 & 8 & 80 & 0 & 8 & 53 \\
economisch-juridisch & - & - & - & - & - & - & - & - & - & - \\
vrije afstudeerrichting & 0 & 0 & 0 & 0 & 0 & 8 & 76 & 0 & 16 & 20 \\
toerisme en recreatie & 0 & 0 & 0 & 0 & 1 & 13 & 70 & 0 & 16 & 18 \\
logistiek & 0 & 0 & 0 & 0 & 0 & 2 & 96 & 0 & 2 & 5 \\
(detail)handel & 0 & 0 & 0 & 1 & 7 & 8 & 63 & 0 & 21 & 88 \\
horeca & 0 & 0 & 0 & 0 & 4 & 1 & 84 & 0 & 10 & 14 \\
overig economie & 0 & 0 & 0 & 0 & 1 & 9 & 73 & 0 & 17 & 70 \\
agogisch werk & 0 & 0 & 0 & 0 & 0 & 3 & 96 & 0 & 1 & 73 \\
verzorging & 0 & 0 & 0 & 0 & 4 & 13 & 79 & 0 & 4 & 18 \\
assistenten gezondheidszorg & 0 & 0 & 0 & 0 & 0 & 9 & 83 & 0 & 8 & 14 \\
mode en kleding & 0 & 0 & 0 & 0 & 1 & 21 & 58 & 0 & 19 & 25 \\
activiteitenbegeleiding & 0 & 0 & 0 & 0 & 0 & 13 & 87 & 0 & 0 & 14 \\
facilitaire dienstverlening & - & - & - & - & - & - & - & - & - & - \\
uiterlijke verzorging & - & - & - & - & - & - & - & - & - & - \\
sociale arbeid & 0 & 1 & 0 & 0 & 0 & 3 & 95 & 0 & 1 & 18 \\
verpleging & 0 & 0 & 0 & 0 & 0 & 6 & 94 & 0 & 0 & 22 \\
overig dienstverlening/verzorging & - & - & - & - & - & - & - & - & - & - \\
overig & 0 & 3 & 1 & 0 & 3 & 16 & 71 & 0 & 6 & 168 \\
\hline Totaal & 0 & 6 & 3 & 0 & 7 & 43 & 28 & 10 & 2 & 8553
\end{tabular}

- = geen gegevens vanwege kleine aantallen

Toelichting

Het gaat hier alleen om de doorstroom naar reguliere voltijdse vervolgopleidingen. Voor de doorstroom naar het leerlingwezen of in-service onderwijs wordt verwezen naar tabel 10. 
Tabel $7 \mathrm{C}$

Belangrijkste vervolgopleidingsrichtingen van verder lerende schoolverlaters per opleidingscluster

$\%$

MAVO

HAVO

18

MBO overig dienstverlening/verzorging

MBO (detail)handel

MBO toerisme en recreatie

12

MBO administratie

HAVO

VW0

$\mathrm{HBO}$ overig economie

$\mathrm{HBO}$ basisonderwijs

WWO

W0 wiskunde en natuurwetenschappen

W0 economie

$\mathrm{HBO}$ overig economie

W0 gezondheidszorg

W0 letteren

W0 rechten

W0 sociale wetenschappen

VBO landbouw

MBO overig landbouw

$\mathrm{MBO}$ groene ruimte

$M B 0$ veehouderij

MBO overig dienstverlening/verzorging

MBO bloemschikken

MBO dierenverzorging

VBO techniek

MBO elektrotechniek MB0 werktuigbouwkunde MBO-kort overig techniek MBO overig techniek MBO-kort consumptieve techniek MBO-kort elektrotechniek MBO-kort overig

VBO economie

MBO-kort administratie

MBO (detail)handel

MBO overig dienstverlening/verzorging

MBO administratie

MBO-kort (detail)handel

MBO overig economie

MBO commercieel 
Tabel 7C (vervolg)

Belangrijkste vervolgopleidingsrichtingen van verder lerende schoolverlaters per opleidingscluster

$\%$

VBO dienstverlening/verzorging

$\mathrm{MBO}$ verzorging

26

MBO overig dienstverlening/verzorging

19

MB0-kort overig

$\mathrm{MB} 0$ verpleging

MBO assistenten gezondheidszorg

$\mathrm{MBO}$ uiterlijke verzorging

MBO-kort techniek

MBO werktuigbouwkunde

Overig

MBO-kort elektrotechniek

MBO overig economie

MBO bouwkunde

HAVO

MBO-kort economie

MBO (detail)handel

MBO administratie

MBO overig economie

MBO secretariaat

Overig

MBO overig dienstverlening/verzorging

MBO economisch-juridisch

MBO-kort dienstverlening/verzorging

$\mathrm{MBO}$ verzorging

MBO overig dienstverlening/verzorging

$\mathrm{MBO}$ verpleging

Overig

46

24

MBO-kort overig

MBO overig dienstverlening/verzorging

$\mathrm{MBO}$ verzorging

MBO assistenten gezondheidszorg

$\mathrm{MBO}$ overig

$\mathrm{MBO}$ landbouw

HBO landbouw

MBO techniek

HBO elektrotechniek

HBO bouwkunde

HBO werktuigbouw, scheeps- en vliegtuigbouw

HBO technische bedrijfskunde

$\mathrm{HBO}$ overig techniek 
Tabel 7C (vervolg)

Belangrijkste vervolgopleidingsrichtingen van verder lerende schoolverlaters per opleidingscluster

\section{$\mathrm{MBO}$ economie}

HBO overig economie

Overig

$\mathrm{HBO}$ bedriffseconomie

$\mathrm{MBO}$ dienstverlening/verzorging

HBO overig sociaal-agogisch

$\mathrm{HBO}$ basisonderwijs

HBO verpleegkunde: overig

HBO maatschappelijk werk

HBO personeelswerk/-beleid

MBO overig

$\mathrm{HBO}$ basisonderwijs

HBO overig sociaal-agogisch

Overig

geen gegevens vanwege kleine aantallen:

VBO overig

MBO-kort landbouw

\section{Toelichting}

Het gaat hier alleen om de doorstroom naar reguliere voltijdse vervolgopleidingen. Voor de doorstroom naar het leerlingwezen of in-service onderwijs wordt verwezen naar tabel 10. 
Tabel 7D

Belangrijkste vervolgopleidingsrichtingen van verder lerende schoolverlaters per opleidingsrichting

$\%$

MAVO

HAVO

18

MBO overig dienstverlening/verzorging

MBO (detail)handel

MBO toerisme en recreatie

12

$\mathrm{MBO}$ administratie

HAVO

VWO

HBO overig economie

$\mathrm{HBO}$ basisonderwijs

vwo

W0 wiskunde en natuurwetenschappen

W0 economie

HBO overig economie

W0 gezondheidszorg

WO letteren

W0 rechten

W0 sociale wetenschappen

VBO landbouw

MBO overig landbouw

$\mathrm{MBO}$ groene ruimte

MBO veehouderij

MBO overig dienstverlening/verzorging

MBO bloemschikken

MBO dierenverzorging

VBO bouwtechniek

MBO bouwkunde

MBO overig techniek

MBO-kort overig techniek

Overig

MBO-kort (detail)handel

MBO bloemschikken

MBO grafische techniek

MBO-kort overig

VBO mechanische techniek

MBO werktuigbouwkunde

MBO-kort overig techniek

MBO-kort overig

VBO mechanische techniek

MBO-kort metaalbewerking

MBO-kort motorv. techniek

MBO-kort werktuigbouw

7

MBO nautisch

VBO elektrotechniek

MBO elektrotechniek 
Tabel 7D (vervolg)

Belangrijkste vervolgopleidingsrichtingen van verder lerende schoolverlaters per opleidingsrichting

$\%$

MBO-kort elektrotechniek

MAVO

VBO consumptieve techniek

MBO-kort consumptieve techniek $\quad 38$

$\begin{array}{ll}\text { MBO horeca } & 17\end{array}$

MBO overig techniek $\quad 16$

MBO-kort overig 10

MBO overig dienstverlening/verzorging

VBO grafische techniek

MBO grafische techniek

MBO-kort overig techniek

MBO-kort overig

VBO grafische techniek

MBO-kort (detail)handel

VBO administratie

MBO-kort administratie

MBO administratie

MBO overig dienstverlening/verzorging

MBO overig economie

$\mathrm{MBO}$ verzorging

VBO verkoop

MBO-kort (detail)handel

MBO-kort administratie

MBO-kort consumptieve techniek

MBO (detail)hande

MBO overig dienstverlening/verzorging

MAVO

MBO commercieel

VBO handel

MBO (detail)hande

MBO commercieel

$\mathrm{MBO}$ overig dienstverlening/verzorging

MBO mode en kleding

VBO verzorging

$\mathrm{MBO}$ verzorging

MBO overig dienstverlening/verzorging

$M B 0$ verpleging

MBO-kort overig

$\mathrm{MBO}$ assistenten gezondheidszorg

$\mathrm{MBO}$-kort verzorging

VBO mode en kleding

MBO-kort overig

MBO mode en kleding 
Tabel 7D (vervolg)

Belangrijkste vervolgopleidingsrichtingen van verder lerende schoolverlaters per opleidingsrichting

\begin{tabular}{lc} 
& $\%$ \\
\hline MBO overig dienstverlening/verzorging & 11 \\
MBO-kort (detail)handel & 9 \\
MBO-kort administratie & 9 \\
MBO mode \& kleding & 9 \\
MBO overig techniek & 7 \\
MBO (detail)handel & 7 \\
MBO overig economie & 5
\end{tabular}

MBO-kort (detail)handel

MBO (detail)handel

50

MBO overig dienstverlening/verzorging

8

MBO-kort overig

MBO grafische techniek

MBO verzorging

MBO mode en kleding

MAVO

Overig

MBO-kort administratie

MBO administratie

$\mathrm{MBO}$ overig economie

MBO secretariaat

MBO economisch-juridisch

MBO (detail)handel

Overig

MBO commercieel

$\mathrm{MBO}$ overig dienstverlening/verzorging

$M B O-k o r t$ verzorging

$\mathrm{MBO}$ verzorging

$\mathrm{MBO}$ overig dienstverlening/verzorging

MBO verpleging

MBO-kort overig

$\mathrm{MBO}$ overig dienstverlening/verzorging

$\mathrm{MBO}$ verzorging

MBO assistenten gezondheidszorg

MBO overig

$\mathrm{MBO}$ plantenteelt

HBO landbouw

$\mathrm{HBO}$ overig economie

$\mathrm{MBO}$ overig landbouw

$M B O$ veehouderij

HBO landbouw

$\mathrm{MBO}$ veehouderij

MBO-kort landbouw 
Tabel 7D (vervolg)

Belangrijkste vervolgopleidingsrichtingen van verder lerende schoolverlaters per opleidingsrichting

MBO levensmiddelentechnologie

HBO landbouw 26

$\mathrm{HBO}$ overig economie $\quad 20$

HBO dietetiek 7

MBO overig dienstverlening/verzorging $\quad 6$

HBO laboratoriumonderwijs $\quad 6$

HBO chemische technologie $\quad 5$

MBO groene ruimte

$\mathrm{HBO}$ landbouw

MBO overig landbouw

MBO bouwkunde

HBO bouwkunde

MBO weg-en waterbouwkunde

MBO (detail)handel

MBO elektrotechniek

HBO elektrotechniek

HBO (hogere) informatica

10

HBO technische bedrifskunde

HBO technische natuurkunde

$M B O$ werktuigbouwkunde

HBO werktuigbouw, scheeps- en vliegtuigbouw

$\mathrm{HBO}$ technische bedrijfskunde

HBO leraar 2e graads techniek

14

HBO technische natuurkunde

12

HBO overig techniek

MBO motorvoertuigentechniek

MBO motorvoertuigentechniek

HBO autotechniek $\quad 31$

HBO werktuigbouw, scheeps- en vliegtuigbouw $\quad 23$

MBO motorvoertuigentechniek $\quad 16$

MBO-kort overig economie $\quad 12$

HBO bouwkunde $\quad 12$

MBO grafische techniek

HBO film/tv, foto, museologie, publiciteit

HBO overig kunst $\quad 13$

MBO grafische techniek 12

HBO overig techniek $\quad 6$

HBO documentatie $\quad 6$

MBO proces- en laboratoriumtechniek

HBO chemische technologie

HBO overig techniek 17

HBO landbouw 12 
Tabel 7D (vervolg)

Belangrijkste vervolgopleidingsrichtingen van verder lerende schoolverlaters per opleidingsrichting

$\%$

HBO laboratoriumonderwijs

MBO (detail)handel

$\mathrm{HBO}$ nautisch

HBO personeelswerk/-beleid

MBO mode \& kleding (techn)

HBO leraar 2e graads expressie

MB0 grafische techniek

HBO basisonderwijs

Overig

HBO creatief-educatief werk

HBO architect, industrieel, mode

MBO administratie

$\mathrm{HBO}$ overig economie

HBO bedriffseconomie

HBO accountancy \& belastingen

Overig

$\mathrm{MBO}$ secretariaat

Overig

HBO econ.-linguistisch \& vertaler

$\mathrm{HBO}$ overig economie

MBO secretariaat

HBO hotel \& toerisme en recreatie

MBO commercieel

HBO overig economie

Overig

HBO basisonderwijs

HBO journalistiek

8

8

$M B O$ vrije afstudeerrichting

HBO overig economie

Overig

HBO personeelswerk/-beleid

$\mathrm{MBO}$ vrije afstudeerrichting

$\mathrm{HBO}$ bedrifseconomie

$\mathrm{HBO}$ technische bedrijfskunde

$\mathrm{HBO}$ werktuigbouw, scheeps- en vliegtuigbouw

$\mathrm{HBO}$ distributie, log.manag, small-bus.

$\mathrm{HBO}$ overig

$M B O$ toerisme en recreatie

HBO hotel \& toerisme en recreatie

Overig

$\mathrm{HBO}$ overig economie

MBO logistiek

HBO distributie, log.manag, small-bus. 
Tabel 7D (vervolg)

Belangrijkste vervolgopleidingsrichtingen van verder lerende schoolverlaters per opleidingsrichting

\begin{tabular}{lr} 
& $\%$ \\
\hline HBO overig economie & 26 \\
HBO landbouw & 6
\end{tabular}

MBO (detail)handel

HBO overig economie

Overig

MBO horeca

HBO overig economie

HBO hotel \& toerisme en recreatie

Overig

HBO bedriifseconomie

HBO technische bedrijfskunde

HBO econ.-linguistisch \& vertaler

MBO overig economie

HBO overig economie

Overig

HBO bedriffseconomie

$\mathrm{HBO}$ overig sociaal-agogisch

HBO personeelswerk/-beleid

$M B O$ agogisch werk

HBO overig sociaal-agogisch

$\mathrm{HBO}$ basisonderwijs

HBO maatschappelijk werk

$M B O$ verzorging

$\mathrm{HBO}$ verpleegkunde: overig

$\mathrm{HBO}$ basisonderwijs

$M B 0$ verpleging

HBO overig sociaal-agogisch

HBO maatschappelijk werk

$\mathrm{MBO}$ assistenten gezondheidszorg

HBO fysio- en ergotherapie

$\mathrm{HBO}$ maatschappelijk werk

HBO paramedische opleiding: overig

$\mathrm{HBO}$ verpleegkunde: overig

HBO dietetiek

Overig

MBO mode en kleding (verz)

HBO leraar 2e graads expressie Overig

HBO architect, industrieel, mode

$\mathrm{HBO}$ basisonderwijs

MBO administratie

MBO overig economie MBO assistenten gezondheidszorg

(17)

6

\section{1}

10

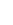


Tabel 7D (vervolg)

Belangrijkste vervolgopleidingsrichtingen van verder lerende schoolverlaters per opleidingsrichting

$\%$

HBO overig sociaal-agogisch

$\mathrm{HBO}$ overig kunst

$\mathrm{MBO}$ activiteitenbegeleiding

HBO overig sociaal-agogisch 35

$\mathrm{HBO}$ basisonderwijs

HBO maatschappelijk werk

HBO leraar le graads lich. oef.

MBO sociale arbeid

$\mathrm{HBO}$ personeelswerk/-beleid

HBO overig sociaal-agogisch

HBO maatschappelijk werk

\section{$M B O$ verpleging}

HBO verpleegkunde: overig HBO overig gezondheidszorg HBO fysio- en ergotherapie HBO overig sociaal-agogisch

$\mathrm{MBO}$ overig

$\mathrm{HBO}$ basisonderwijs

HBO overig sociaal-agogisch

Overig

geen gegevens vanwege kleine aantallen:

VBO motorvoertuigentechniek

VBO installatietechniek

VBO overig techniek

VBO uiterlijke verzorging

VBO overig

MBO-kort landbouw

MBO-kort elektrotechniek

MBO-kort motorv. techniek

MBO-kort consumptieve techniek

MBO-kort werktuigbouw

MBO-kort overig techniek

MBO-kort overig dienstverlening/verzorging

MBO bloemschikken

MBO dierenverzorging

MBO overig landbouw

MBO weg- en waterbouwkunde

MBO mechanische techniek

MBO overig techniek

MBO economisch-juridisch

MBO facilitaire dienstverlening

MBO uiterlijke verzorging

MBO overig dienstverlening/verzorging

\section{Toelichting}

Het gaat hier alleen om de doorstroom naar reguliere voltijdse vervolgopleidingen. Voor de doorstroom naar het leerlingwezen of in-service onderwijs wordt verwezen naar tabel 10. 
Tabel 8A

Oordeel van de verder lerende schoolverlaters over de aansluiting van de afgesloten opleiding met de vervolgopleiding per opleidingscluster

\begin{tabular}{|c|c|c|c|c|c|}
\hline Opleidingscluster & $\begin{array}{c}\text { goed } \\
\%\end{array}$ & $\begin{array}{c}\text { voldoende } \\
\%\end{array}$ & $\begin{array}{c}\text { matig } \\
\%\end{array}$ & $\begin{array}{c}\text { slecht } \\
\%\end{array}$ & $\begin{array}{c}\text { Totaal } \\
\mathrm{N}=100 \%\end{array}$ \\
\hline AVO & 41 & 39 & 15 & 5 & 5643 \\
\hline MAVO & 40 & 40 & 16 & 4 & 2563 \\
\hline HAVO & 35 & 40 & 19 & 7 & 1647 \\
\hline VWO & 50 & 35 & 11 & 4 & 1432 \\
\hline VBO & 41 & 36 & 15 & 8 & 1454 \\
\hline landbouw & 44 & 33 & 15 & 9 & 170 \\
\hline techniek & 39 & 35 & 18 & 8 & 485 \\
\hline economie & 44 & 37 & 13 & 6 & 367 \\
\hline dienstverlening/verzorging & 42 & 37 & 13 & 7 & 411 \\
\hline overig & - & - & - & - & - \\
\hline MBO-kort & 34 & 39 & 21 & 6 & 330 \\
\hline landbouw & - & - & - & - & - \\
\hline techniek & 21 & 28 & 45 & 7 & 30 \\
\hline economie & 34 & 41 & 19 & 6 & 170 \\
\hline dienstverlening/verzorging & 37 & 50 & 13 & 0 & 36 \\
\hline overig & 37 & 35 & 21 & 7 & 91 \\
\hline MBO-tussen en -lang & 33 & 43 & 17 & 7 & 1169 \\
\hline landbouw & 20 & 42 & 26 & 11 & 57 \\
\hline techniek & 31 & 47 & 11 & 11 & 341 \\
\hline economie & 40 & 39 & 17 & 4 & 396 \\
\hline dienstverlening/verzorging & 26 & 44 & 23 & 8 & 208 \\
\hline overig & 38 & 40 & 15 & 7 & 168 \\
\hline Totaal & 40 & 39 & 16 & 6 & 8596 \\
\hline
\end{tabular}

Toelichting

Vraag in de enquête: Hoe vind je de aansluiting tussen je opleiding van vorig jaar en je huidige bezigheden?

Het gaat hier alleen om schoolverlaters die doorstromen naar reguliere voltijdse vervolgopleidingen. 
Tabel 8B

Oordeel van de verder lerende schoolverlaters over de aansluiting van de afgesloten opleiding met de vervolgopleiding per opleidingsrichting

\begin{tabular}{lccccc} 
Opleidingsrichting & goed & voldoende & matig & slecht & $\begin{array}{c}\text { Totaal } \\
\mathbf{N}=\mathbf{1 0 0 \%}\end{array}$ \\
& $\%$ & $\%$ & $\%$ & $\%$ & \\
\hline AVO & & & & & \\
MAVO & 40 & 40 & 16 & 4 & 2563 \\
HAVO & 35 & 40 & 19 & 7 & 1647 \\
WWO & 50 & 35 & 11 & 4 & 1432
\end{tabular}

VBO

landbouw

bouwtechniek

44
31

mechanische techniek

33

elektrotechniek

motorvoertuigentechniek

48

consumptieve techniek

48

installatietechniek

grafische techniek

overig techniek

administratie

$-$

verkoop

handel

verzorging

uiterlijke verzorging

mode en kleding

overig

15

170

MBO-kort

landbouw

elektrotechniek

motorv. techniek

consumptieve techniek

werktuigbouw

overig techniek

(detail)handel

administratie

verzorging

overig dienstverlening/verzorging

overig

MBO-tussen en -lang

plantenteelt

veehouderij

levensmiddelentechnologie

bloemschikken

dierenverzorging

groene ruimte

overig landbouw

bouwkunde

elektrotechniek

werktuigbouwkunde

weg- en waterbouwkunde

motorvoertuigentechniek

mechanische techniek

$\begin{array}{rr}39 & 27 \\ 45 & 28 \\ 41 & 13 \\ - & \\ - & \\ 42 & 28 \\ - & \\ 51 & 11 \\ 48 & 16 \\ 51 & \\ - & \\ 19 & \\ - & \end{array}$

$\begin{array}{rrr}27 & 14 & 13 \\ 28 & 11 & 16 \\ 13 & 12 & 7 \\ - & - & - \\ - & - & - \\ 28 & 10 & 14 \\ - & - & - \\ 11 & 10 & 62 \\ 16 & 11 & 112 \\ 9 & 1 & 71 \\ - & - & - \\ 5 & 37 & 17 \\ - & - & -\end{array}$


Tabel 8B (vervolg)

Oordeel van de verder lerende schoolverlaters over de aansluiting van de afgesloten opleiding met de vervolgopleiding per opleidingsrichting

\begin{tabular}{|c|c|c|c|c|c|}
\hline Opleidingsrichting & $\begin{array}{c}\text { goed } \\
\%\end{array}$ & $\begin{array}{c}\text { voldoende } \\
\%\end{array}$ & $\begin{array}{c}\text { matig } \\
\%\end{array}$ & $\begin{array}{c}\text { slecht } \\
\%\end{array}$ & $\begin{array}{c}\text { Totaal } \\
N=100 \%\end{array}$ \\
\hline grafische techniek & 33 & 39 & 16 & 12 & 5 \\
\hline proces- en laboratoriumtechniek & 37 & 47 & 5 & 11 & 31 \\
\hline mode \& kleding (techn) & 26 & 41 & 16 & 17 & 25 \\
\hline overig techniek & - & - & - & - & - \\
\hline administratie & 50 & 34 & 12 & 4 & 101 \\
\hline secretariaat & 30 & 45 & 23 & 2 & 22 \\
\hline commercieel & 44 & 38 & 13 & 5 & 53 \\
\hline economisch-juridisch & - & - & - & - & - \\
\hline vrije afstudeerrichting & 39 & 53 & 7 & 1 & 20 \\
\hline toerisme en recreatie & 28 & 42 & 27 & 4 & 18 \\
\hline logistiek & 18 & 40 & 30 & 12 & 4 \\
\hline (detail)handel & 28 & 41 & 25 & 6 & 87 \\
\hline horeca & 42 & 44 & 9 & 5 & 14 \\
\hline overig economie & 43 & 40 & 15 & 3 & 68 \\
\hline agogisch werk & 29 & 46 & 21 & 4 & 72 \\
\hline verzorging & 22 & 40 & 35 & 4 & 18 \\
\hline assistenten gezondheidszorg & 25 & 40 & 28 & 7 & 13 \\
\hline mode en kleding & 25 & 32 & 15 & 29 & 25 \\
\hline activiteitenbegeleiding & 29 & 36 & 27 & 7 & 14 \\
\hline facilitaire dienstverlening & - & - & - & - & - \\
\hline uiterlijke verzorging & - & - & - & - & - \\
\hline sociale arbeid & 32 & 40 & 22 & 7 & 18 \\
\hline verpleging & 20 & 52 & 26 & 2 & 22 \\
\hline overig dienstverlening/verzorging & - & - & - & - & - \\
\hline overig & 38 & 40 & 15 & 7 & 168 \\
\hline Totaal & 40 & 39 & 16 & 6 & 8596 \\
\hline
\end{tabular}

\section{Toelichting}

Vraag in de enquête: Hoe vind je de aansluiting tussen je opleiding van vorig jaar en je huidige bezigheden?

Het gaat hier alleen om schoolverlaters die doorstromen naar reguliere voltijdse vervolgopleidingen. 
Kerngegevens / Schoolverlaters tussen onderwijs en arbeidsmarkt 1995 
Tabel 9

Percentage verder lerende schoolverlaters dat van mening is dat aan de onderscheiden aspecten van de afgesloten opleiding meer aandacht zou moeten worden besteed per opleidingscluster

\begin{tabular}{|c|c|c|c|c|c|c|}
\hline & MAVO & HAVO & vwo & $\begin{array}{l}\text { VBO } \\
\text { land- } \\
\text { bouw }\end{array}$ & $\begin{array}{c}\text { VBO } \\
\text { tech- } \\
\text { niek }\end{array}$ & $\begin{array}{c}\text { VBO } \\
\text { eco- } \\
\text { nomie }\end{array}$ \\
\hline & $\%$ & $\%$ & $\%$ & $\%$ & $\%$ & $\%$ \\
\hline Leren studeren & 27 & 29 & 24 & 28 & 42 & 32 \\
\hline Vreemde talen & 20 & 16 & 16 & 43 & 41 & 42 \\
\hline Met ciffers werken & 21 & 17 & 16 & 20 & 37 & 23 \\
\hline Informatica, automatisering & 68 & 79 & 83 & 55 & 49 & 46 \\
\hline Zelfstandig werken & 49 & 45 & 35 & 37 & 38 & 46 \\
\hline Organiseren/plannen & 51 & 56 & 42 & 48 & 48 & 44 \\
\hline Correcte spelling/foutloos schrijven & 27 & 30 & 25 & 23 & 28 & 35 \\
\hline Een verslag of rapport schrijven & 50 & 58 & 62 & 33 & 33 & 45 \\
\hline Spreekvaardigheid & 32 & 43 & 46 & 19 & 29 & 30 \\
\hline Met klanten/patiënten omgaan & 39 & 32 & 18 & 40 & 34 & 34 \\
\hline Beroepskeuze/studiekeuze & 40 & 48 & 35 & 33 & 39 & 43 \\
\hline Leren solliciteren & 50 & 51 & 44 & 47 & 37 & 48 \\
\hline Vakkennis en vaktheorie & 32 & 34 & 23 & 38 & 31 & 29 \\
\hline Praktijkorientage of stage & 58 & 55 & 36 & 37 & 47 & 38 \\
\hline Omgaan met apparatuur of materialen & 50 & 46 & 39 & 45 & 37 & 35 \\
\hline Kennis van organisatie bedrijf & 43 & 38 & 28 & 52 & 46 & 39 \\
\hline Kennis van arbeidsvoorwaarden & 47 & 51 & 37 & 59 & 56 & 52 \\
\hline Commerciele kennënten en verkooptechniek & 35 & 29 & 21 & 36 & 28 & 28 \\
\hline Samenwerken met collega's/medestudenten & 29 & 33 & 36 & 24 & 29 & 28 \\
\hline Onderscheiden van hoofd- en bijzaken & 31 & 36 & 35 & 32 & 32 & 26 \\
\hline
\end{tabular}

- = geen gegevens vanwege kleine aantallen

\section{Toelichting}

Vraag in de enquête: Hieronder noemen we een aantal onderwerpen. Moet daaraan in de opleiding die je vorig jaar hebt verlaten méér, evenveel of minder aandacht worden besteed?

Gepresenteerd is het percentage schoolverlaters dat vindt dat aan een aspect meer aandacht zou moeten worden besteed.

Het gaat hier alleen om schoolverlaters die doorstromen naar reguliere voltijdse vervolgopleidingen. 


\begin{tabular}{|c|c|c|c|c|c|c|c|c|c|c|c|c|}
\hline $\begin{array}{c}\text { VBO } \\
\text { dienst } \\
\text { verl./ } \\
\text { verz } \\
\%\end{array}$ & $\begin{array}{c}\text { VBO } \\
\text { overig }\end{array}$ & $\begin{array}{c}\text { MBO- } \\
\text { kort } \\
\text { land- } \\
\text { bouw } \\
\%\end{array}$ & $\begin{array}{l}\text { MBO- } \\
\text { kort } \\
\text { tech- } \\
\text { niek } \\
\%\end{array}$ & $\begin{array}{c}\text { MBO- } \\
\text { kort } \\
\text { eco- } \\
\text { nomie } \\
\%\end{array}$ & $\begin{array}{c}\text { MBO- } \\
\text { kort } \\
\text { dienst } \\
\text { verl./verz } \\
\%\end{array}$ & $\begin{array}{c}\text { MBO- } \\
\text { kort } \\
\text { overig } \\
\\
\%\end{array}$ & $\begin{array}{c}\text { MBO } \\
\text { land- } \\
\text { bouw } \\
\%\end{array}$ & $\begin{array}{c}\text { MBO } \\
\text { tech- } \\
\text { niek } \\
\\
\%\end{array}$ & $\begin{array}{c}\text { MBO } \\
\text { eco- } \\
\text { nomie } \\
\% \\
\%\end{array}$ & $\begin{array}{c}\text { MBO } \\
\text { dienst } \\
\text { verl./ } \\
\text { verz } \\
\%\end{array}$ & $\begin{array}{l}\text { MBO } \\
\text { overig }\end{array}$ & Totaal \\
\hline 44 & - & - & 33 & 41 & 34 & 42 & 25 & 25 & 27 & 42 & 34 & 30 \\
\hline 46 & - & - & 48 & 42 & 47 & 43 & 50 & 31 & 23 & 55 & 21 & 25 \\
\hline 36 & - & - & 63 & 34 & 27 & 26 & 41 & 37 & 33 & 35 & 26 & 23 \\
\hline 38 & - & - & 57 & 50 & 41 & 45 & 67 & 67 & 61 & 65 & 49 & 67 \\
\hline 48 & - & - & 34 & 40 & 44 & 32 & 27 & 34 & 39 & 37 & 38 & 43 \\
\hline 49 & - & - & 31 & 38 & 48 & 33 & 50 & 44 & 56 & 49 & 50 & 49 \\
\hline 45 & - & - & 38 & 38 & 54 & 38 & 41 & 37 & 29 & 56 & 45 & 30 \\
\hline 51 & - & - & 39 & 45 & 64 & 48 & 44 & 45 & 54 & 54 & 51 & 52 \\
\hline 34 & - & - & 32 & 39 & 45 & 32 & 38 & 39 & 47 & 47 & 41 & 38 \\
\hline 44 & - & - & 27 & 37 & 38 & 39 & 29 & 26 & 38 & 25 & 27 & 32 \\
\hline 53 & - & - & 73 & 50 & 41 & 54 & 44 & 54 & 58 & 55 & 46 & 44 \\
\hline 53 & - & - & 53 & 49 & 59 & 54 & 39 & 60 & 52 & 50 & 52 & 49 \\
\hline 33 & - & - & 32 & 31 & 37 & 49 & 30 & 27 & 29 & 38 & 28 & 31 \\
\hline 64 & - & - & 29 & 24 & 35 & 48 & 13 & 22 & 36 & 19 & 44 & 47 \\
\hline 35 & - & - & 28 & 40 & 52 & 37 & 31 & 37 & 33 & 34 & 39 & 43 \\
\hline 36 & - & - & 49 & 39 & 29 & 40 & 35 & 41 & 50 & 30 & 42 & 39 \\
\hline 52 & - & - & 47 & 54 & 49 & 48 & 48 & 53 & 52 & 51 & 48 & 48 \\
\hline 23 & - & - & 33 & 32 & 12 & 32 & 32 & 31 & 33 & 17 & 18 & 29 \\
\hline 41 & - & - & 23 & 38 & 42 & 32 & 27 & 25 & 41 & 26 & 32 & 32 \\
\hline 29 & - & - & 22 & 28 & 38 & 26 & 34 & 28 & 35 & 37 & 39 & 33 \\
\hline
\end{tabular}


Tabel 10A

Duale opleiding van verder lerende schoolverlaters per opleidingscluster

\begin{tabular}{|c|c|c|c|c|c|}
\hline Opleidingscluster & $\begin{array}{c}\text { primair } \\
\text { LLW } \\
\%\end{array}$ & $\begin{array}{c}\text { voortgezet } \\
\text { LLW } \\
\%\end{array}$ & $\begin{array}{c}\text { tertiair } \\
\text { LLW } \\
\%\end{array}$ & $\begin{array}{c}\text { in-service } \\
\%\end{array}$ & $\begin{array}{c}\text { Totaal } \\
\mathrm{N}=100 \%\end{array}$ \\
\hline AVO & 59 & 17 & 2 & 22 & 136 \\
\hline MAVO & 73 & 15 & 3 & 9 & 93 \\
\hline HAVO & - & - & - & - & - \\
\hline VW0 & - & - & - & - & - \\
\hline VBO & 87 & 10 & 1 & 2 & 662 \\
\hline landbouw & 78 & 20 & 0 & 2 & 29 \\
\hline techniek & 92 & 8 & 1 & 0 & 493 \\
\hline economie & 80 & 16 & 3 & 0 & 61 \\
\hline dienstverlening/verzorging & 68 & 16 & 0 & 16 & 71 \\
\hline overig & - & - & - & - & - \\
\hline MBO-kort & 39 & 54 & 0 & 7 & 152 \\
\hline landbouw & - & - & - & - & - \\
\hline techniek & 28 & 72 & 0 & 1 & 83 \\
\hline economie & - & - & - & - & - \\
\hline dienstverlening/verzorging & 19 & 55 & 0 & 26 & 29 \\
\hline overig & - & - & - & - & - \\
\hline MBO-tussen en -lang & 22 & 15 & 1 & 61 & 127 \\
\hline landbouw & 44 & 37 & 15 & 4 & 8 \\
\hline techniek & 48 & 49 & 0 & 3 & 26 \\
\hline economie & 57 & 29 & 0 & 14 & 8 \\
\hline dienstverlening/verzorging & 7 & 2 & 0 & 91 & 83 \\
\hline overig & - & - & - & - & - \\
\hline Totaal & 69 & 17 & 1 & 13 & 1088 \\
\hline
\end{tabular}

\section{Toelichting}

Het gaat hier alleen om de doorstroom naar het leerlingwezen en het in-service onderwijs. Voor de doorstroom naar het regulier voltijdonderwijs wordt verwezen naar tabel 7. 
Tabel 10B

Duale opleiding van verder lerende schoolverlaters, verbijzonderd naar leerlingstelsel en in-service onderwijs per opleidingscluster

\begin{tabular}{|c|c|c|c|c|c|c|c|c|c|c|c|c|c|c|}
\hline \multirow[t]{2}{*}{ Opleidingscluster } & \multirow{2}{*}{$\begin{array}{c}\text { LO } \\
\text { BAS } \\
\%\end{array}$} & \multirow{2}{*}{$\begin{array}{c}\text { SO } \\
\text { BEB } \\
\%\end{array}$} & \multirow{2}{*}{$\begin{array}{c}\text { svo } \\
\\
\%\end{array}$} & \multicolumn{2}{|c|}{$\begin{array}{l}\text { VOC/SH+M } \\
\text { BETEX }\end{array}$} & \multicolumn{2}{|c|}{ GOC SOM } & VEV & voc & VVA & SVB & SBW & \multirow{2}{*}{$\begin{array}{c}\text { IN } \\
\text { TECH } \\
\text { NUM } \\
\%\end{array}$} & \multirow{2}{*}{$\begin{array}{l}\text { SVS } \\
\%\end{array}$} \\
\hline & & & & $\%$ & $\%$ & $\%$ & $\%$ & $\%$ & $\%$ & $\%$ & $\%$ & $\%$ & & \\
\hline AVO & 0 & 4 & 2 & 0 & 2 & 2 & 8 & 0 & 0 & 0 & 0 & 0 & 2 & 0 \\
\hline MAVO & 0 & 6 & 0 & 0 & 3 & 3 & 12 & 0 & 0 & 0 & 0 & 0 & 3 & 0 \\
\hline HAVO & - & - & - & - & - & - & - & - & - & - & - & - & - & - \\
\hline VW0 & - & - & - & - & - & - & - & - & - & - & - & - & - & - \\
\hline VBO & 3 & 5 & 1 & 0 & 7 & 0 & 16 & 6 & 3 & 0 & 8 & 2 & 4 & 3 \\
\hline landbouw & 44 & 0 & 0 & 0 & 4 & 1 & 8 & 0 & 0 & 0 & 0 & 2 & 0 & 1 \\
\hline techniek & 1 & 6 & 0 & 0 & 9 & 1 & 20 & 8 & 3 & 0 & 10 & 2 & 5 & 5 \\
\hline economie & 0 & 0 & 6 & 0 & 0 & 0 & 2 & 0 & 0 & 0 & 0 & 3 & 0 & 0 \\
\hline dienstverlening/verzorging & 3 & 6 & 5 & 2 & 1 & 0 & 0 & 0 & 0 & 0 & 0 & 0 & 0 & 0 \\
\hline overig & - & - & - & - & - & - & - & - & - & - & - & - & - & - \\
\hline MBO-kort & 1 & 2 & 0 & 0 & 1 & 1 & 8 & 6 & 0 & 0 & 3 & 0 & 0 & 1 \\
\hline landbouw & - & - & - & - & - & - & - & - & - & - & - & - & - & - \\
\hline techniek & 0 & 3 & 0 & 0 & 2 & 1 & 13 & 10 & 0 & 0 & 4 & 0 & 0 & 0 \\
\hline economie & - & - & - & - & - & - & - & - & - & - & - & - & - & - \\
\hline dienstverlening/verzorging & 0 & 0 & 0 & 0 & 0 & 0 & 0 & 0 & 0 & 0 & 0 & 0 & 0 & 0 \\
\hline overig & - & - & - & - & - & - & - & - & - & - & - & - & - & - \\
\hline MBO-tussen en -lang & 4 & 0 & 0 & 0 & 0 & 1 & 5 & 5 & 0 & 0 & 2 & 2 & 1 & 0 \\
\hline landbouw & 58 & 0 & 0 & 0 & 0 & 0 & 10 & 0 & 0 & 0 & 0 & 4 & 0 & 0 \\
\hline techniek & 2 & 0 & 0 & 0 & 0 & 0 & 19 & 23 & 0 & 0 & 7 & 8 & 2 & 0 \\
\hline economie & 0 & 3 & 0 & 0 & 0 & 0 & 0 & 0 & 0 & 3 & 0 & 4 & 4 & 0 \\
\hline dienstverlening/verzorging & 0 & 0 & 0 & 0 & 0 & 0 & 0 & 0 & 0 & 0 & 0 & 0 & 0 & 0 \\
\hline overig & - & - & - & - & - & - & - & - & - & - & - & - & - & - \\
\hline Totaal & 2 & 4 & 1 & 0 & 5 & 1 & 12 & 5 & 2 & 0 & 5 & 2 & 3 & 2 \\
\hline
\end{tabular}




\begin{tabular}{|c|c|c|c|c|c|c|c|c|c|c|c|c|c|c|c|c|}
\hline $\begin{array}{c}\text { IN } \\
\text { NO } \\
\text { VAM } \\
\%\end{array}$ & SLW & KOF & SVGB & SVK & SVH & OVD & $\begin{array}{c}\text { ECA } \\
\text { BO }\end{array}$ & OVD & $\begin{array}{c}\text { LLW } \\
\text { overig } \\
\quad \%\end{array}$ & $\begin{array}{c}\text { In- } \\
\text { serv } \\
\text { A } \\
\%\end{array}$ & $\begin{array}{c}\text { In- } \\
\text { serv } \\
\text { B } \\
\%\end{array}$ & $\begin{array}{c}\text { In- } \\
\text { serv } \\
\mathbf{Z} \\
\%\end{array}$ & $\begin{array}{c}\text { In- } \\
\text { serv } \\
\text { ZV } \\
\%\end{array}$ & $\begin{array}{c}\text { In- } \\
\text { serv } \\
\text { OK } \\
\%\end{array}$ & $\begin{array}{c}\text { ove- } \\
\text { rig } \\
\%\end{array}$ & $\begin{array}{c}\text { Totaal } \\
N=100 \%\end{array}$ \\
\hline 2 & 4 & 4 & 0 & 4 & 10 & 4 & 19 & 7 & 2 & 19 & 0 & 4 & 0 & 0 & 0 & 139 \\
\hline 3 & 6 & 6 & 0 & 6 & 15 & 6 & 12 & 6 & 3 & 6 & 0 & 3 & 0 & 0 & 0 & 93 \\
\hline- & - & - & - & - & - & - & - & - & - & - & - & - & - & - & - & - \\
\hline- & - & - & - & - & - & - & - & - & - & - & - & - & - & - & - & - \\
\hline 10 & 5 & 2 & 0 & 3 & 7 & 5 & 2 & 3 & 3 & 0 & 0 & 0 & 2 & 0 & 1 & 668 \\
\hline 8 & 1 & 0 & 0 & 4 & 8 & 8 & 3 & 2 & 4 & 0 & 0 & 0 & 2 & 0 & 0 & 29 \\
\hline 13 & 4 & 2 & 0 & 0 & 7 & 1 & 0 & 0 & 3 & 0 & 0 & 0 & 0 & 0 & 1 & 499 \\
\hline 0 & 18 & 0 & 0 & 6 & 12 & 29 & 17 & 2 & 5 & 0 & 0 & 0 & 0 & 0 & 0 & 61 \\
\hline 0 & 0 & 0 & 0 & 23 & 5 & 8 & 0 & 30 & 1 & 0 & 0 & 0 & 16 & 0 & 0 & 71 \\
\hline- & - & - & - & - & - & - & - & - & - & - & - & - & - & - & - & - \\
\hline 14 & 2 & 0 & 0 & 6 & 14 & 1 & 13 & 14 & 7 & 1 & 0 & 0 & 6 & 0 & 1 & 153 \\
\hline- & - & - & - & - & - & - & - & - & - & - & - & - & - & - & - & - \\
\hline 26 & 2 & 0 & 0 & 0 & 24 & 0 & 2 & 0 & 11 & 0 & 0 & 0 & 1 & 0 & 0 & 83 \\
\hline- & - & - & - & - & - & - & - & - & - & - & - & - & - & - & - & - \\
\hline 0 & 0 & 0 & 0 & 24 & 0 & 0 & 3 & 46 & 0 & 0 & 0 & 0 & 26 & 0 & 0 & 29 \\
\hline- & - & - & - & - & - & - & - & - & - & - & - & - & - & - & - & - \\
\hline 4 & 0 & 0 & 0 & 1 & 4 & 1 & 5 & 1 & 1 & 14 & 4 & 17 & 24 & 0 & 3 & 131 \\
\hline 0 & 0 & 0 & 0 & 0 & 0 & 4 & 4 & 2 & 13 & 0 & 2 & 0 & 2 & 0 & 2 & 8 \\
\hline 20 & 0 & 0 & 0 & 0 & 0 & 0 & 7 & 0 & 0 & 2 & 0 & 0 & 1 & 0 & 8 & 28 \\
\hline 0 & 0 & 3 & 2 & 3 & 20 & 0 & 31 & 0 & 3 & 7 & 0 & 0 & 5 & 0 & 12 & 9 \\
\hline 0 & 0 & 0 & 0 & 1 & 5 & 1 & 1 & 2 & 0 & 21 & 6 & 27 & 36 & 1 & 0 & 84 \\
\hline - & - & - & - & - & - & - & - & - & - & - & - & - & - & - & - & - \\
\hline 9 & 4 & 1 & 0 & 3 & 8 & 4 & 6 & 5 & 3 & 4 & 0 & 3 & 5 & 0 & 1 & 1091 \\
\hline
\end{tabular}


Kerngegevens / Schoolverlaters tussen onderwijs en arbeidsmarkt 1995 
3. Intrede op de arbeidsmarkt 
Kerngegevens / Schoolverlaters tussen onderwijs en arbeidsmarkt 1995 
Tabel 11B

Duur van de intredewerkloosheid van schoolverlaters die zich aanbieden op de arbeidsmarkt per opleidingsrichting

\begin{tabular}{lcccccr} 
Opleidingsrichting & $\mathbf{0}$ mnd & $\mathbf{1 - 3}$ mnd & $\mathbf{4 - 6}$ mnd & $\mathbf{7 6}$ mnd & $\begin{array}{c}\text { gemid- } \\
\text { deld }\end{array}$ & $\begin{array}{r}\text { Totaal } \\
\mathbf{N}=\mathbf{1 0 0} \%\end{array}$ \\
& $\%$ & $\%$ & $\%$ & $\%$ & & \\
\hline AVO & 71 & 20 & 9 & 0 & 0,9 & 157 \\
MAVO & 66 & 15 & 9 & 10 & 1,7 & 124 \\
HAVO & 66 & 26 & 5 & 3 & 1,0 & 62 \\
WWO & & & & & &
\end{tabular}

VBO

BO

bouwtechniek

76

0,5

1,1

列

elektrotechniek

motorvoertuigentechniek

consumptieve techniek

installatietechniek

grafische techniek

overig techniek

administratie

verkoop

handel

verzorging

uiterlijke verzorging

mode en kleding

overig

MBO-kort

landbouw

elektrotechniek

motorv. techniek

consumptieve techniek

werktuigbouw

overig techniek

(detail)handel

administratie

verzorging

3

10 
Tabel 11B (vervolg)

Duur van de intredewerkloosheid van schoolverlaters die zich aanbieden op de arbeidsmarkt per opleidingsrichting

\begin{tabular}{|c|c|c|c|c|c|c|}
\hline Opleidingsrichting & $\begin{array}{c}0 \text { mnd } \\
\%\end{array}$ & $\begin{array}{c}1-3 \text { mnd } \\
\%\end{array}$ & $\begin{array}{c}\text { 4-6 mnd } \\
\%\end{array}$ & $\begin{array}{c}>6 \text { mnd } \\
\%\end{array}$ & $\begin{array}{l}\text { gemid- } \\
\text { deld }\end{array}$ & $\begin{array}{c}\text { Totaal } \\
N=100 \%\end{array}$ \\
\hline grafische techniek & 55 & 28 & 10 & 7 & 1,8 & 16 \\
\hline proces- en laboratoriumtechniek & 48 & 37 & 9 & 6 & 1,5 & 46 \\
\hline mode \& kleding (techn) & 53 & 35 & 6 & 7 & 1,3 & 35 \\
\hline overig techniek & 74 & 11 & 9 & 6 & 1,1 & 47 \\
\hline administratie & 58 & 27 & 8 & 7 & 1,4 & 75 \\
\hline secretariaat & 58 & 28 & 9 & 5 & 1,4 & 89 \\
\hline commercieel & 67 & 16 & 13 & 3 & 1,2 & 51 \\
\hline economisch-juridisch & - & - & - & - & - & - \\
\hline vrije afstudeerrichting & 60 & 21 & 13 & 6 & 1,9 & 24 \\
\hline toerisme en recreatie & 59 & 26 & 10 & 6 & 1,5 & 40 \\
\hline logistiek & 77 & 21 & 0 & 2 & 0,6 & 4 \\
\hline (detail)handel & 61 & 23 & 11 & 5 & 1,5 & 171 \\
\hline horeca & 68 & 23 & 8 & 0 & 0,9 & 38 \\
\hline overig economie & 41 & 39 & 17 & 3 & 1,9 & 70 \\
\hline agogisch werk & 56 & 19 & 13 & 12 & 2,2 & 114 \\
\hline verzorging & 74 & 17 & 5 & 3 & 0,9 & 123 \\
\hline assistenten gezondheidszorg & 59 & 22 & 12 & 7 & 1,7 & 80 \\
\hline mode \& kleding (verz) & 64 & 27 & 6 & 2 & 1,1 & 38 \\
\hline activiteitenbegeleiding & 60 & 20 & 10 & 9 & 1,8 & 31 \\
\hline facilitaire dienstverlening & 69 & 18 & 7 & 6 & 1,2 & 23 \\
\hline uiterlijke verzorging & 74 & 16 & 5 & 5 & 1,0 & 24 \\
\hline sociale arbeid & 72 & 12 & 3 & 13 & 1,8 & 14 \\
\hline verpleging & 65 & 20 & 10 & 6 & 1,4 & 23 \\
\hline overig dienstverlening/verzorging & - & - & - & - & - & - \\
\hline overig & - & - & - & - & - & - \\
\hline Totaal & 64 & 21 & 9 & 5 & 1,3 & 3310 \\
\hline
\end{tabular}

- = geen gegevens vanwege kleine aantallen

Toelichting

Vraag in de enquête: Hoeveel maanden ben je in totaal werkloos geweest na het verlaten van deze opleiding?

Het gaat hier alleen om schoolverlaters die tot de beroepsbevolking behoren en bovendien niet doorstromen naar het voltijd dagonderwijs. Tot de beroepsbevolking behoren die schoolverlaters die:

- ten minste 12 uur per week werken;

- werk hebben aanvaard waardoor zij ten minste 12 uur per week gaan werken;

- ten minste 12 uur per week willen werken, daarvoor beschikbaar zijn en daartoe tevens activiteiten ontplooien.

(zie CBS, Enquête Beroepsbevolking 1994, Voorburg/Heerlen) 
Tabel 12A

Werkloosheid onder schoolverlaters per opleidingscluster, 1994 en 1995

\begin{tabular}{|c|c|c|c|c|}
\hline \multirow[t]{2}{*}{ Opleidingscluster } & 1994 & $\begin{array}{c}\text { Totaal } \\
N=100 \%\end{array}$ & 1995 & $\begin{array}{c}\text { Totaal } \\
N=100 \%\end{array}$ \\
\hline & $\%$ & & $\%$ & \\
\hline AVO & 15 & 460 & 10 & 385 \\
\hline MAVO & 18 & 263 & 6 & 177 \\
\hline HAVO & - & - & 16 & 139 \\
\hline VWO & - & - & 7 & 69 \\
\hline VBO & 7 & 1054 & 4 & 895 \\
\hline landbouw & 6 & 59 & 2 & 39 \\
\hline techniek & 6 & 652 & 2 & 595 \\
\hline economie & 9 & 137 & 10 & 119 \\
\hline dienstverlening/verzorging & 8 & 186 & 7 & 133 \\
\hline overig & - & - & - & - \\
\hline MBO-kort & 10 & 636 & 11 & 522 \\
\hline landbouw & 9 & 45 & 4 & 14 \\
\hline techniek & 9 & 257 & 8 & 204 \\
\hline economie & 8 & 273 & 12 & 220 \\
\hline dienstverlening/verzorging & 22 & 56 & 19 & 58 \\
\hline overig & - & - & 15 & 26 \\
\hline MBO-tussen en -lang & 7 & 2143 & 6 & 1854 \\
\hline landbouw & 2 & 117 & 3 & 126 \\
\hline techniek & 8 & 652 & 5 & 565 \\
\hline economie & 6 & 690 & 6 & 614 \\
\hline dienstverlening/verzorging & 7 & 613 & 7 & 523 \\
\hline overig & 3 & 70 & 15 & 26 \\
\hline Totaal & 8 & 4294 & 7 & 3656 \\
\hline
\end{tabular}

- = geen gegevens vanwege kleine aantallen

\section{Toelichting}

Dit betreft de Geregistreerde werkloosheid conform CBS-definitie, dat wil zeggen:

- ingeschreven bij een arbeidsbureau;

- niet of minder dan 12 uur per week werken;

- beschikbaar zijn voor een baan voor 12 uur of meer per week of werk hebben aanvaard waardoor men ten minste 12 uur per week gaat werken.

(zie CBS, Enquête Beroepsbevolking 1994, Voorburg/Heerlen).

Het aantal werkloze schoolverlaters is, in afwijking van de CBS-definitie, niet gerelateerd aan het aantal schoolverlaters dat tot de beroepsbevolking behoort, maar aan het aantal schoolverlaters dat tot de beroepsbevolking behoort en niet doorstroomt naar het voltijd dagonderwijs (zie ook de toelichting bij tabel 11). 
Tabel 12B

Werkloosheid onder schoolverlaters per opleidingsrichting, 1994 en 1995

\begin{tabular}{lccrr} 
Opleidingsrichting & 1994 & $\begin{array}{c}\text { Totaal } \\
\mathbf{N}=100 \%\end{array}$ & 1995 & $\begin{array}{r}\text { Totaal } \\
\mathbf{N}=100 \%\end{array}$ \\
\hline AVO & $\%$ & & & \\
MAVO & 18 & 263 & 6 & 177 \\
HAVO & - & - & 16 & 139 \\
WWO & - & - & 7 & 69
\end{tabular}

VBO

landbouw

bouwtechniek

mechanische techniek

elektrotechniek

motorvoertuigentechniek

consumptieve techniek

installatietechniek

grafische techniek

overig techniek

administratie

verkoop

handel

verzorging

uiterlijke verzorging

mode en kleding

overig

MBO-kort

landbouw

elektrotechniek

motorv. techniek

consumptieve techniek

werktuigbouw

overig techniek

(detail)handel

administratie

verzorging

overig dienstverlening/verzorging

overig

$\begin{array}{rrrr}8 & 47 & 2 & 39 \\ 6 & 177 & 2 & 170 \\ 5 & 131 & 3 & 102 \\ 6 & 91 & 0 & 81 \\ 5 & 95 & 0 & 107 \\ 9 & 103 & 7 & 90 \\ - & - & - & - \\ - & - & - & - \\ - & - & - & - \\ 9 & 63 & 8 & 55 \\ 10 & 49 & 12 & 43 \\ . & . & - & - \\ 7 & 107 & 9 & 93 \\ 7 & 32 & - & - \\ . & . & - & - \\ - & - & - & -\end{array}$

MBO-tussen en -lang

plantenteelt

veehouderij

levensmiddelentechnologie

bloemschikken

dierenverzorging

groene ruimte

overig landbouw

bouwkunde

elektrotechniek

werktuigbouwkunde

weg- en waterbouwkunde

motorvoertuigentechniek

mechanische techniek

grafische techniek

$\begin{array}{rrrr}9 & 45 & 4 & 14 \\ 17 & 58 & 9 & 25 \\ 9 & 41 & 3 & 47 \\ 7 & 45 & 7 & 55 \\ . & - & 7 & 38 \\ 6 & 68 & 13 & 39 \\ 6 & 99 & 11 & 79 \\ 10 & 174 & 12 & 141 \\ 15 & 48 & 19 & 42 \\ - & - & - & - \\ - & - & 15 & 26\end{array}$


Tabel 12B (vervolg)

Werkloosheid onder schoolverlaters per opleidingsrichting, 1994 en 1995

Opleidingsrichting
1994

$\%$

Totaal

$\mathrm{N}=100 \%$

1995

Totaal

$\mathrm{N}=100 \%$

proces- en laboratoriumtechniek

nautisch

mode \& kleding (techn)

overig techniek

administratie

secretariaat

commercieel

economisch-juridisch

vrije afstudeerrichting

toerisme en recreatie

logistiek

(detail)handel

horeca

overig economie

agogisch werk

verzorging

assistenten gezondheidszorg

mode \& kleding (verz)

activiteitenbegeleiding

facilitaire dienstverlening

uiterlijke verzorging

sociale arbeid

verpleging

overig dienstverlening/verzorging

overig

Totaal

- = geen gegevens vanwege kleine aantallen

. = geen gegevens voorhanden

$\begin{array}{lll}. & 1 & 52\end{array}$

52

38

50

76

93

56

-

26

42

5

183

39

80

124

137

86

43

33

26

26

16

24

26 3656

\section{Toelichting}

Dit betreft de Geregistreerde werkloosheid conform CBS-definitie, dat wil zeggen:

- ingeschreven bij een arbeidsbureau;

- niet of minder dan 12 uur per week werken;

- beschikbaar zijn voor een baan voor 12 uur of meer per week of werk hebben aanvaard waardoor men ten minste 12 uur per week gaat werken.

(zie CBS, Enquête Beroepsbevolking 1994, Voorburg/Heerlen).

Het aantal werkloze schoolverlaters is, in afwijking van de CBS-definitie, niet gerelateerd aan het aantal schoolverlaters dat tot de beroepsbevolking behoort, maar aan het aantal schoolverlaters dat tot de beroepsbevolking behoort en niet doorstroomt naar het voltijd dagonderwijs (zie ook de toelichting bii tabel 11). 
Kerngegevens / Schoolverlaters tussen onderwijs en arbeidsmarkt 1995 
Tabel 13A

Wijze van het verkrijgen van een baan per opleidingscluster

$\begin{array}{cccccc}\text { Opleidingscluster } & \begin{array}{c}\text { arbeids- } \\ \text { bureau }\end{array} & \begin{array}{c}\text { uitzend- } \\ \text { bureau }\end{array} & \begin{array}{c}\text { adver- } \\ \text { tentie }\end{array} & \begin{array}{c}\text { familie/ } \\ \text { kennis- } \\ \text { sen }\end{array} & \begin{array}{c}\text { eerder } \\ \text { werk }\end{array}\end{array}$

\begin{tabular}{|c|c|c|c|c|c|}
\hline & $\%$ & $\%$ & $\%$ & $\%$ & $\%$ \\
\hline AVO & 9 & 20 & 18 & 14 & 10 \\
\hline MAVO & 13 & 10 & 17 & 19 & 15 \\
\hline HAVO & 2 & 30 & 17 & 11 & 6 \\
\hline VWO & 13 & 24 & 21 & 7 & 6 \\
\hline VBO & 7 & 9 & 9 & 19 & 6 \\
\hline landbouw & 6 & 12 & 3 & 18 & 10 \\
\hline techniek & 6 & 10 & 7 & 19 & 5 \\
\hline economie & 5 & 8 & 14 & 14 & 6 \\
\hline dienstverlening/verzorging & 11 & 7 & 18 & 26 & 7 \\
\hline overig & - & - & - & - & - \\
\hline MBO-kort & 10 & 15 & 14 & 13 & 7 \\
\hline landbouw & 6 & 14 & 10 & 17 & 8 \\
\hline techniek & 8 & 10 & 12 & 13 & 5 \\
\hline economie & 10 & 22 & 19 & 13 & 8 \\
\hline dienstverlening/verzorging & 19 & 14 & 9 & 11 & 6 \\
\hline overig & - & - & - & - & - \\
\hline MBO-tussen en -lang & 8 & 18 & 15 & 12 & 9 \\
\hline landbouw & 5 & 10 & 9 & 17 & 8 \\
\hline techniek & 9 & 21 & 12 & 15 & 8 \\
\hline economie & 10 & 25 & 17 & 11 & 10 \\
\hline dienstverlening/verzorging & 6 & 7 & 17 & 8 & 7 \\
\hline overig & - & - & - & - & - \\
\hline
\end{tabular}

- = geen gegevens vanwege kleine aantallen 


\begin{tabular}{|c|c|c|c|c|c|c|c|}
\hline $\begin{array}{c}\text { werk- } \\
\text { gever } \\
\text { heeft } \\
\text { mij } \\
\text { gevraagd } \\
\%\end{array}$ & $\begin{array}{c}\text { zelf } \\
\text { werk } \\
\text { gevraagd }\end{array}$ & $\begin{array}{l}\text { werk- } \\
\text { erva- } \\
\text { rings- } \\
\text { project } \\
\quad \%\end{array}$ & $\begin{array}{c}\text { zelf } \\
\text { bedrijf } \\
\text { begonnen }\end{array}$ & school & stage & anders & $\begin{array}{c}\text { Totaal } \\
N=100 \%\end{array}$ \\
\hline 0 & 21 & 0 & 0 & 1 & 3 & 6 & 303 \\
\hline 0 & 15 & 0 & 0 & 2 & 6 & 4 & 135 \\
\hline 0 & 30 & 0 & 0 & 0 & 0 & 4 & 107 \\
\hline 0 & 17 & 0 & 0 & 0 & 0 & 12 & 61 \\
\hline 2 & 18 & 2 & 0 & 10 & 11 & 7 & 725 \\
\hline 2 & 12 & 4 & 4 & 7 & 13 & 9 & 31 \\
\hline 1 & 17 & 1 & 0 & 13 & 13 & 8 & 489 \\
\hline 1 & 31 & 4 & 0 & 5 & 5 & 7 & 89 \\
\hline 3 & 14 & 6 & 0 & 2 & 4 & 2 & 109 \\
\hline - & - & - & - & - & - & - & - \\
\hline 2 & 11 & 4 & 1 & 4 & 17 & 1 & 391 \\
\hline 1 & 12 & 6 & 1 & 3 & 17 & 4 & 12 \\
\hline 3 & 12 & 2 & 0 & 6 & 27 & 2 & 154 \\
\hline 1 & 6 & 4 & 2 & 3 & 11 & 1 & 168 \\
\hline 0 & 23 & 8 & 0 & 0 & 10 & 0 & 39 \\
\hline- & - & - & - & - & - & - & - \\
\hline 2 & 15 & 2 & 2 & 2 & 14 & 2 & 1514 \\
\hline 3 & 11 & 2 & 11 & 3 & 18 & 3 & 108 \\
\hline 2 & 11 & 1 & 2 & 2 & 17 & 1 & 421 \\
\hline 2 & 9 & 2 & 2 & 2 & 9 & 2 & 519 \\
\hline 2 & 26 & 1 & 0 & 2 & 17 & 4 & 449 \\
\hline- & - & - & - & - & - & - & - \\
\hline 2 & 16 & 2 & 1 & 4 & 13 & 4 & 2933 \\
\hline
\end{tabular}


Tabel 13B

Wijze van het verkrijgen van een baan per opleidingsrichting

$\begin{array}{cccccc}\text { Opleidingsrichting } & \begin{array}{c}\text { arbeids- } \\ \text { bureau }\end{array} & \begin{array}{c}\text { uitzend- } \\ \text { bureau }\end{array} & \begin{array}{c}\text { adver- } \\ \text { tentie }\end{array} & \begin{array}{c}\text { familie/ } \\ \text { kennis- } \\ \text { sen }\end{array} & \begin{array}{c}\text { eerder } \\ \text { werk }\end{array}\end{array}$

\begin{tabular}{|c|c|c|c|c|c|}
\hline & $\%$ & $\%$ & $\%$ & $\%$ & $\%$ \\
\hline \multicolumn{6}{|l|}{ AVO } \\
\hline MAVO & 13 & 10 & 17 & 19 & 15 \\
\hline HAVO & 2 & 30 & 17 & 11 & 6 \\
\hline WW0 & 13 & 24 & 21 & 7 & 6 \\
\hline \multicolumn{6}{|l|}{ VBO } \\
\hline landbouw & 6 & 12 & 3 & 18 & 10 \\
\hline bouwtechniek & 4 & 6 & 3 & 15 & 3 \\
\hline mechanische techniek & 6 & 13 & 13 & 19 & 6 \\
\hline elektrotechniek & - & - & - & - & - \\
\hline motorvoertuigentechniek & 7 & 10 & 7 & 23 & 3 \\
\hline consumptieve techniek & 8 & 7 & 2 & 19 & 3 \\
\hline installatietechniek & - & - & - & - & - \\
\hline grafische techniek & - & - & - & - & - \\
\hline overig techniek & - & - & - & - & - \\
\hline administratie & - & - & - & - & - \\
\hline verkoop & - & - & - & - & - \\
\hline handel & - & - & - & - & - \\
\hline verzorging & 13 & 3 & 23 & 24 & 8 \\
\hline uiterlijke verzorging & - & - & - & - & - \\
\hline mode en kleding & - & - & - & - & - \\
\hline overig & - & - & - & - & . \\
\hline
\end{tabular}

MBO-kort

landbouw

elektrotechniek

14

17

16

8

motorv. techniek

consumptieve techniek

werktuigbouw

overig techniek

(detail)handel

administratie

verzorging

overig dienstverlening/verzorging

overig

MBO-tussen en -lang

plantenteelt

veehouderij

levensmiddelentechnologie

bloemschikken

dierenverzorging

groene ruimte

overig landbouw

bouwkunde

elektrotechniek

werktuigbouwkunde

weg- en waterbouwkunde 


\begin{tabular}{|c|c|c|c|c|c|c|c|}
\hline $\begin{array}{c}\text { werk- } \\
\text { gever } \\
\text { heeft } \\
\text { mij } \\
\text { gevraagd } \\
\%\end{array}$ & $\begin{array}{c}\begin{array}{c}\text { zelf } \\
\text { werk } \\
\text { gevraagd }\end{array} \\
\%\end{array}$ & $\begin{array}{c}\text { werk- } \\
\text { erva- } \\
\text { rings- } \\
\text { project } \\
\% \\
\%\end{array}$ & $\begin{array}{c}\text { zelf } \\
\text { bedrijf } \\
\text { begonnen }\end{array}$ & school & stage & anders & $\begin{array}{c}\text { Totaal } \\
\mathrm{N}=100 \%\end{array}$ \\
\hline 0 & 15 & 0 & 0 & 2 & 6 & 4 & 135 \\
\hline 0 & 30 & 0 & 0 & 0 & 0 & 4 & 107 \\
\hline 0 & 17 & 0 & 0 & 0 & 0 & 12 & 61 \\
\hline 2 & 12 & 4 & 4 & 7 & 13 & 9 & 31 \\
\hline 2 & 8 & 3 & 1 & 26 & 7 & 20 & 129 \\
\hline 0 & 16 & 0 & 0 & 10 & 13 & 3 & 90 \\
\hline- & - & - & - & - & - & - & - \\
\hline 0 & 17 & 0 & 0 & 7 & 27 & 0 & 91 \\
\hline 3 & 39 & 0 & 0 & 6 & 4 & 8 & 75 \\
\hline- & - & - & - & - & - & - & - \\
\hline- & - & - & - & - & - & - & - \\
\hline- & - & - & - & - & - & - & - \\
\hline- & - & - & - & - & - & - & - \\
\hline- & - & - & - & - & - & - & - \\
\hline- & - & - & - & - & - & - & - \\
\hline 1 & 13 & 6 & 0 & 1 & 5 & 3 & 71 \\
\hline- & - & - & - & - & - & - & - \\
\hline- & - & - & - & - & - & - & - \\
\hline- & - & - & - & - & - & - & - \\
\hline 1 & 12 & 6 & 1 & 3 & 17 & 4 & 12 \\
\hline 6 & 12 & 0 & 0 & 0 & 19 & 0 & 18 \\
\hline- & - & - & - & - & - & - & - \\
\hline 1 & 12 & 0 & 0 & 3 & 33 & 4 & 41 \\
\hline- & - & - & - & - & - & - & - \\
\hline 4 & 14 & 7 & 0 & 4 & 32 & 4 & 28 \\
\hline 0 & 9 & 5 & 2 & 2 & 16 & 0 & 62 \\
\hline 2 & 5 & 4 & 2 & 3 & 8 & 1 & 106 \\
\hline 0 & 24 & 11 & 0 & 0 & 7 & 0 & 28 \\
\hline- & - & - & - & - & - & - & - \\
\hline- & - & - & - & - & - & - & - \\
\hline 3 & 7 & 1 & 16 & 3 & 12 & 2 & 25 \\
\hline 8 & 9 & 1 & 18 & 1 & 9 & 5 & 30 \\
\hline 0 & 17 & 5 & 0 & 2 & 13 & 2 & 10 \\
\hline 1 & 10 & 2 & 9 & 2 & 35 & 2 & 15 \\
\hline 0 & 11 & 4 & 0 & 4 & 28 & 2 & 7 \\
\hline 2 & 17 & 2 & 1 & 5 & 28 & 2 & 18 \\
\hline- & - & - & - & - & - & - & - \\
\hline 1 & 9 & 0 & 5 & 4 & 21 & 1 & 62 \\
\hline 1 & 11 & 1 & 1 & 0 & 21 & 1 & 110 \\
\hline 0 & 11 & 2 & 1 & 2 & 10 & 3 & 82 \\
\hline 16 & 21 & 0 & 0 & 2 & 6 & 0 & 14 \\
\hline
\end{tabular}


Tabel 13B (vervolg)

Wijze van het verkrijgen van een baan per opleidingsrichting

$\begin{array}{cccccc}\text { Opleidingsrichting } & \begin{array}{c}\text { arbeids- } \\ \text { bureau }\end{array} & \begin{array}{c}\text { uitzend- } \\ \text { bureau }\end{array} & \begin{array}{c}\text { adver- } \\ \text { tentie }\end{array} & \begin{array}{c}\text { familie/ } \\ \text { kennis- } \\ \text { sen }\end{array} & \begin{array}{c}\text { eerder } \\ \text { werk }\end{array}\end{array}$

\begin{tabular}{|c|c|c|c|c|c|}
\hline & $\%$ & $\%$ & $\%$ & $\%$ & $\%$ \\
\hline motorvoertuigentechniek & 0 & 35 & 18 & 3 & 9 \\
\hline mechanische techniek & - & - & - & - & - \\
\hline grafische techniek & 4 & 12 & 14 & 12 & 5 \\
\hline proces- en laboratoriumtechniek & 9 & 54 & 3 & 4 & 2 \\
\hline nautisch & - & - & - & - & - \\
\hline mode \& kleding (techn) & 18 & 25 & 19 & 8 & 10 \\
\hline overig techniek & 7 & 17 & 5 & 22 & 12 \\
\hline administratie & 15 & 38 & 11 & 6 & 10 \\
\hline secretariaat & 9 & 41 & 13 & 10 & 8 \\
\hline commercieel & 7 & 33 & 20 & 13 & 8 \\
\hline economisch-juridisch & - & - & - & - & - \\
\hline vrije afstudeerrichting & 13 & 33 & 12 & 14 & 4 \\
\hline toerisme en recreatie & 4 & 18 & 17 & 5 & 3 \\
\hline logistiek & 9 & 27 & 29 & 6 & 3 \\
\hline (detail)handel & 11 & 11 & 18 & 15 & 14 \\
\hline horeca & 8 & 7 & 22 & 13 & 14 \\
\hline overig economie & 8 & 30 & 23 & 10 & 8 \\
\hline agogisch werk & 7 & 8 & 20 & 8 & 7 \\
\hline verzorging & 5 & 3 & 14 & 6 & 6 \\
\hline assistenten gezondheidszorg & 2 & 5 & 19 & 9 & 8 \\
\hline mode \& kleding (verz) & 15 & 10 & 16 & 17 & 12 \\
\hline activiteitenbegeleiding & 11 & 5 & 23 & 4 & 11 \\
\hline facilitaire dienstverlening & 9 & 13 & 5 & 16 & 11 \\
\hline uiterlijke verzorging & 6 & 8 & 28 & 7 & 4 \\
\hline sociale arbeid & 3 & 30 & 21 & 6 & 12 \\
\hline verpleging & 7 & 11 & 18 & 2 & 8 \\
\hline overig dienstverlening/verzorging & - & - & - & - & - \\
\hline overig & - & - & - & - & - \\
\hline Totaal & 8 & 15 & 14 & 14 & 8 \\
\hline
\end{tabular}

- = geen gegevens vanwege kleine aantallen 


\begin{tabular}{|c|c|c|c|c|c|c|c|}
\hline $\begin{array}{c}\text { werk- } \\
\text { gever } \\
\text { heeft } \\
\text { mij } \\
\text { gevraagd } \\
\%\end{array}$ & $\begin{array}{c}\begin{array}{c}\text { zelf } \\
\text { werk } \\
\text { gevraagd }\end{array} \\
\%\end{array}$ & $\begin{array}{c}\text { werk- } \\
\text { erva- } \\
\text { rings- } \\
\text { project } \\
\% \\
\%\end{array}$ & $\begin{array}{c}\text { zelf } \\
\text { bedrijf } \\
\text { begonnen }\end{array}$ & school & stage & anders & $\begin{array}{c}\text { Totaal } \\
N=100 \%\end{array}$ \\
\hline 9 & 10 & 0 & 1 & 0 & 14 & 0 & 25 \\
\hline - & - & - & - & - & - & - & - \\
\hline 4 & 12 & 2 & 2 & 5 & 22 & 6 & 15 \\
\hline 0 & 9 & 2 & 0 & 1 & 16 & 0 & 34 \\
\hline - & - & - & - & - & - & - & - \\
\hline 0 & 12 & 0 & 0 & 2 & 6 & 0 & 34 \\
\hline 0 & 10 & 0 & 5 & 0 & 22 & 0 & 41 \\
\hline 2 & 8 & 1 & 0 & 2 & 6 & 2 & 64 \\
\hline 1 & 6 & 2 & 1 & 4 & 4 & 1 & 85 \\
\hline 2 & 6 & 1 & 1 & 2 & 3 & 5 & 45 \\
\hline - & - & - & - & - & - & - & - \\
\hline 3 & 8 & 0 & 0 & 2 & 11 & 0 & 22 \\
\hline 3 & 18 & 0 & 0 & 1 & 30 & 0 & 38 \\
\hline 7 & 15 & 0 & 0 & 0 & 3 & 3 & 3 \\
\hline 1 & 10 & 1 & 4 & 1 & 12 & 1 & 145 \\
\hline 5 & 14 & 0 & 1 & 2 & 12 & 3 & 36 \\
\hline 0 & 3 & 11 & 0 & 4 & 1 & 1 & 71 \\
\hline 0 & 26 & 1 & 0 & 2 & 15 & 7 & 103 \\
\hline 1 & 43 & 1 & 0 & 1 & 16 & 4 & 119 \\
\hline 5 & 20 & 0 & 0 & 7 & 23 & 1 & 76 \\
\hline 4 & 3 & 2 & 1 & 0 & 16 & 4 & 36 \\
\hline 3 & 15 & 2 & 0 & 2 & 23 & 2 & 27 \\
\hline 7 & 15 & 0 & 0 & 4 & 13 & 8 & 21 \\
\hline 2 & 13 & 0 & 1 & 1 & 29 & 2 & 22 \\
\hline 0 & 10 & 4 & 4 & 2 & 8 & 0 & 14 \\
\hline 2 & 38 & 2 & 0 & 3 & 3 & 6 & 21 \\
\hline - & - & - & - & - & - & - & - \\
\hline- & - & - & - & - & - & - & - \\
\hline 2 & 16 & 2 & 1 & 4 & 13 & 4 & 2933 \\
\hline
\end{tabular}


Tabel 14A

Bruto maandloon van de werkende schoolverlaters per opleidingscluster

\begin{tabular}{|c|c|c|c|c|c|c|c|c|}
\hline Opleidingscluster & $\begin{array}{c}=<750 \\
\text { gld } \\
\%\end{array}$ & $\begin{array}{c}751- \\
1250 \\
\text { gld } \\
\%\end{array}$ & $\begin{array}{c}1251- \\
1750 \\
\text { gld } \\
\%\end{array}$ & $\begin{array}{c}1751- \\
2250 \\
\text { gld } \\
\%\end{array}$ & $\begin{array}{l}2251- \\
2750 \\
\text { gld } \\
\%\end{array}$ & $\begin{array}{c}>2750 \\
\text { gld } \\
\%\end{array}$ & $\begin{array}{l}\text { gemid- } \\
\text { deld } \\
\text { gld }\end{array}$ & $\begin{array}{c}\text { Totaal } \\
N=100 \%\end{array}$ \\
\hline AVO & 26 & 35 & 32 & 7 & 1 & 0 & 1098 & 260 \\
\hline MAVO & 34 & 39 & 27 & 0 & 0 & 0 & 953 & 115 \\
\hline HAVO & 18 & 31 & 43 & 7 & 0 & 0 & 1186 & 94 \\
\hline VW0 & - & - & - & - & - & - & - & - \\
\hline VBO & 29 & 45 & 17 & 6 & 0 & 2 & 1038 & 615 \\
\hline landbouw & 31 & 50 & 18 & 0 & 0 & 1 & 979 & 26 \\
\hline techniek & 25 & 47 & 20 & 6 & 0 & 2 & 1077 & 423 \\
\hline economie & 33 & 50 & 8 & 8 & 0 & 2 & 986 & 71 \\
\hline dienstverlening/verzorging & 46 & 33 & 12 & 7 & 0 & 1 & 923 & 90 \\
\hline overig & - & - & - & - & - & - & - & - \\
\hline MBO-kort & 5 & 34 & 37 & 14 & 6 & 3 & 1467 & 308 \\
\hline landbouw & 8 & 26 & 41 & 13 & 4 & 8 & 1536 & 8 \\
\hline techniek & 3 & 30 & 37 & 18 & 5 & 7 & 1603 & 120 \\
\hline economie & 5 & 35 & 38 & 13 & 9 & 0 & 1429 & 133 \\
\hline dienstverlening/verzorging & 9 & 47 & 34 & 11 & 0 & 0 & 1237 & 30 \\
\hline overig & - & - & - & - & - & - & - & - \\
\hline MBO-tussen en -lang & 4 & 12 & 24 & 27 & 21 & 13 & 1988 & 1198 \\
\hline landbouw & 4 & 14 & 23 & 22 & 19 & 17 & 2000 & 74 \\
\hline techniek & 3 & 4 & 9 & 24 & 35 & 26 & 2401 & 343 \\
\hline economie & 2 & 12 & 30 & 32 & 15 & 8 & 1883 & 425 \\
\hline dienstverlening/verzorging & 5 & 17 & 32 & 26 & 16 & 4 & 1734 & 342 \\
\hline overig & - & - & - & - & - & - & - & - \\
\hline Totaal & 13 & 26 & 25 & 18 & 11 & 7 & 1578 & 2380 \\
\hline
\end{tabular}

\section{Toelichting}

Dit betreft het bruto maandloon in de baan waarin men het meeste aantal uren werkt. Dit is inclusief toeslagen voor ploegendienst of fooien, maar exclusief vakantiegeld, inkomen uit overwerk of inkomen op basis van een uitkering.

Het gaat hier alleen om werkende schoolverlaters die niet doorstromen naar het voltijd dagonderwijs. 
Tabel 14B

Bruto maandloon van de werkende schoolverlaters per opleidingsrichting

$\begin{array}{ccccccccc}\text { Opleidingscluster } & =<750 & 751- & 1251- & 1751- & 2251- & >2750 & \text { gemid- } & \text { Totaal } \\ & & 1250 & 1750 & 2250 & 2750 & \text { deld } N=100 \% \\ & \text { gld } & \text { gld } & \text { gld } & \text { gld } & \text { gld } & \text { gld } & \text { gld } & \\ \% & \% & \% & \% & \% & \% & \end{array}$

\begin{tabular}{lrrrrrrrr}
\hline AVO & & & & & & & & \\
MAVO & 34 & 39 & 27 & 0 & 0 & 0 & 953 & 115 \\
HAVO & 18 & 31 & 43 & 7 & 0 & 0 & 1186 & 94 \\
WWO & - & - & - & - & - & - & - & -
\end{tabular}

VBO

landbouw

bouwtechniek

mechanische techniek

$\begin{array}{rrrrrrrr}31 & 50 & 18 & 0 & 0 & 1 & 979 & 26 \\ 7 & 52 & 35 & 6 & 0 & 0 & 1187 & 118 \\ 37 & 37 & 11 & 7 & 0 & 7 & 1130 & 79 \\ - & - & - & - & - & - & - & - \\ 30 & 59 & 4 & 4 & 0 & 4 & 955 & 82 \\ 11 & 42 & 37 & 10 & 0 & 0 & 1193 & 62 \\ - & - & - & - & - & - & - & - \\ - & - & - & - & - & - & - & - \\ - & - & - & - & - & - & - & - \\ - & - & - & - & - & - & - & - \\ - & - & - & - & - & - & - & - \\ - & - & - & - & - & - & - & - \\ 46 & 27 & 16 & 10 & 0 & 1 & 991 & 64 \\ - & - & - & - & - & - & - & - \\ - & - & - & - & - & - & - & - \\ - & - & - & - & - & - & - & -\end{array}$

motorvoertuigentechniek

consumptieve techniek

installatietechniek

grafische techniek

overig techniek

administratie

verkoop

handel

verzorging

uiterlijke verzorging

mode en kleding

overig

MBO-kort

landbouw

elektrotechniek

motorv. techniek

consumptieve techniek

werktuigbouw

overig techniek

(detail)handel

administratie

verzorging

overig dienstverlening/verzorging overig

MBO-tussen en -lang

plantenteelt

veehouderij

levensmiddelentechnologie

bloemschikken

dierenverzorging

groene ruimte

overig landbouw

bouwkunde

elektrotechniek

werktuigbouwkunde

weg- en waterbouwkunde

motorvoertuigentechniek

mechanische techniek

$\begin{array}{rrrrrrrr}8 & 26 & 41 & 13 & 4 & 8 & 1536 & 8 \\ 4 & 20 & 25 & 28 & 14 & 10 & 1905 & 14 \\ - & - & - & - & - & - & - & - \\ 6 & 26 & 40 & 20 & 7 & 2 & 1493 & 30 \\ - & - & - & - & - & - & - & - \\ - & - & - & - & - & - & - & - \\ 9 & 52 & 24 & 9 & 6 & 0 & 1273 & 47 \\ 3 & 26 & 46 & 15 & 10 & 1 & 1513 & 87 \\ 3 & 60 & 31 & 6 & 0 & 0 & 1193 & 20 \\ - & - & - & - & - & - & - & \\ - & - & - & - & - & - & - & - \\ & & & & & & & \\ & & & & & & & \\ 1 & 8 & 17 & 25 & 26 & 22 & 2292 & 16 \\ 4 & 14 & 25 & 25 & 14 & 18 & 1997 & 18 \\ 0 & 11 & 14 & 19 & 29 & 27 & 2262 & 7 \\ 10 & 27 & 37 & 20 & 5 & 0 & 1411 & 9 \\ 7 & 27 & 37 & 25 & 2 & 0 & 1455 & 6 \\ 4 & 10 & 12 & 19 & 29 & 25 & 2157 & 15 \\ - & - & - & - & - & - & - & - \\ 4 & 2 & 5 & 29 & 32 & 28 & 2482 & 51 \\ 2 & 3 & 10 & 28 & 37 & 19 & 2316 & 101 \\ 3 & 3 & 3 & 15 & 43 & 34 & 2573 & 65 \\ - & - & - & - & - & - & - & - \\ 0 & 0 & 1 & 18 & 64 & 17 & 2564 & 15 \\ - & - & - & - & - & - & - & -\end{array}$


Tabel 14B (vervolg)

Bruto maandloon van de werkende schoolverlaters per opleidingsrichting

\begin{tabular}{|c|c|c|c|c|c|c|c|c|}
\hline Opleidingscluster & $\begin{array}{c}=<750 \\
\text { gld } \\
\%\end{array}$ & $\begin{array}{c}751- \\
1250 \\
\text { gld } \\
\%\end{array}$ & $\begin{array}{c}1251- \\
1750 \\
\text { gld } \\
\%\end{array}$ & $\begin{array}{c}1751- \\
2250 \\
\text { gld } \\
\%\end{array}$ & $\begin{array}{l}2251- \\
2750 \\
\text { gld } \\
\%\end{array}$ & $\begin{array}{c}>2750 \\
\text { gld } \\
\%\end{array}$ & $\begin{array}{l}\text { gemid- } \\
\text { deld } \\
\text { gld }\end{array}$ & $\begin{array}{c}\text { Totaal } \\
\mathrm{N}=100 \%\end{array}$ \\
\hline grafische techniek & 1 & 3 & 8 & 23 & 44 & 21 & 2394 & 13 \\
\hline proces- en laboratoriumtechniek & 0 & 1 & 3 & 19 & 33 & 45 & 2784 & 27 \\
\hline nautisch & - & - & - & - & - & - & - & - \\
\hline mode \& kleding (techn) & 12 & 26 & 34 & 19 & 7 & 1 & 1386 & 26 \\
\hline overig techniek & 3 & 3 & 13 & 29 & 23 & 29 & 2488 & 31 \\
\hline administratie & 2 & 11 & 33 & 31 & 18 & 4 & 1847 & 49 \\
\hline secretariaat & 2 & 15 & 35 & 27 & 19 & 2 & 1770 & 66 \\
\hline commercieel & 1 & 14 & 38 & 30 & 10 & 7 & 1785 & 37 \\
\hline economisch-juridisch & - & - & - & - & - & - & - & - \\
\hline vrije afstudeerrichting & 2 & 9 & 25 & 46 & 15 & 3 & 1880 & 20 \\
\hline toerisme en recreatie & 0 & 7 & 20 & 32 & 28 & 12 & 2101 & 32 \\
\hline logistiek & - & - & - & - & - & - & - & - \\
\hline (detail)handel & 4 & 20 & 28 & 30 & 13 & 6 & 1769 & 118 \\
\hline horeca & 1 & 2 & 14 & 17 & 18 & 48 & 2639 & 34 \\
\hline overig economie & 3 & 3 & 38 & 47 & 8 & 0 & 1794 & 60 \\
\hline agogisch werk & 12 & 17 & 34 & 18 & 16 & 2 & 1575 & 79 \\
\hline verzorging & 3 & 15 & 32 & 25 & 19 & 6 & 1815 & 85 \\
\hline assistenten gezondheidszorg & 0 & 9 & 20 & 47 & 20 & 3 & 1975 & 61 \\
\hline mode \& kleding (verz) & 6 & 25 & 47 & 12 & 9 & 1 & 1394 & 28 \\
\hline activiteitenbegeleiding & 0 & 19 & 41 & 25 & 9 & 5 & 1743 & 20 \\
\hline facilitaire dienstverlening & 1 & 34 & 22 & 29 & 9 & 5 & 1616 & 16 \\
\hline uiterlijke verzorging & 4 & 31 & 32 & 24 & 9 & 0 & 1529 & 17 \\
\hline sociale arbeid & 2 & 11 & 29 & 21 & 14 & 24 & 2091 & 12 \\
\hline verpleging & 4 & 4 & 33 & 28 & 22 & 8 & 1964 & 18 \\
\hline overig dienstverlening/verzorging & - & - & - & - & - & - & - & - \\
\hline overig & - & - & - & - & - & - & - & - \\
\hline Totaal & 13 & 26 & 25 & 18 & 11 & 7 & 1578 & 2380 \\
\hline
\end{tabular}

\section{Toelichting}

Dit betreft het bruto maandloon in de baan waarin men het meeste aantal uren werkt. Dit is inclusief toeslagen voor ploegendienst of fooien, maar exclusief vakantiegeld, inkomen uit overwerk of inkomen op basis van een uitkering.

Het gaat hier alleen om werkende schoolverlaters die niet doorstromen naar het voltijd dagonderwijs. 
Tabel 15A

Bruto uurloon van de werkende schoolverlaters per opleidingscluster

Opleidingscluster

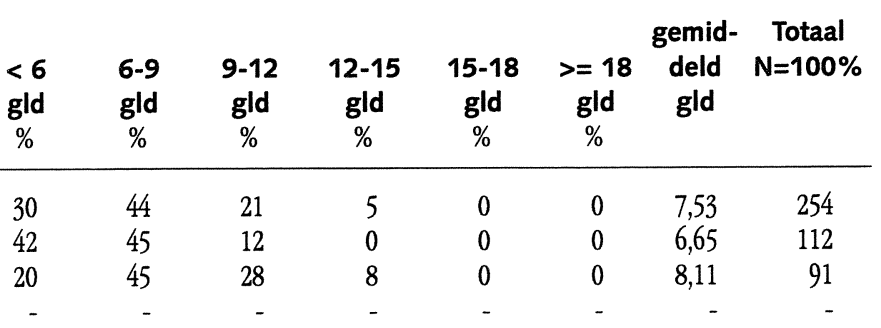

VW0

\begin{tabular}{lrrrrrrrr} 
VBO & 39 & 39 & 18 & 3 & 0 & 1 & 7,08 & 608 \\
landbouw & 27 & 55 & 14 & 3 & 0 & 1 & 7,16 & 26 \\
techniek & 38 & 38 & 20 & 2 & 1 & 1 & 7,17 & 419 \\
economie & 39 & 41 & 15 & 3 & 0 & 2 & 7,22 & 71 \\
dienstverlening/verzorging & 45 & 38 & 13 & 3 & 0 & 1 & 6,59 & 89 \\
overig & - & - & - & - & - & - & - & - \\
MBO-kort & 8 & 42 & 29 & 13 & 6 & 3 & 9,75 & 305 \\
landbouw & 2 & 39 & 34 & 15 & 4 & 6 & 10,44 & 8 \\
techniek & 5 & 36 & 32 & 15 & 8 & 4 & 10,16 & 120 \\
economie & 8 & 48 & 25 & 13 & 4 & 2 & 9,59 & 131 \\
dienstverlening/verzorging & 12 & 40 & 32 & 6 & 8 & 2 & 9,49 & 30 \\
overig & - & - & - & - & - & - & - & - \\
& & & & & & & & \\
MBO-tussen en -lang & 2 & 14 & 29 & 29 & 17 & 9 & 12,79 & 1182 \\
landbouw & 4 & 16 & 28 & 27 & 16 & 9 & 12,40 & 73 \\
techniek & 2 & 6 & 19 & 31 & 27 & 15 & 14,46 & 340 \\
economie & 2 & 17 & 39 & 26 & 11 & 6 & 11,88 & 422 \\
dienstverlening/verzorging & 3 & 16 & 27 & 32 & 13 & 8 & 12,50 & 332 \\
overig & - & - & - & - & - & - & - & - \\
\hline Totaal & 15 & 27 & 25 & 18 & 9 & 5 & 10,35 & 2350
\end{tabular}

- = geen gegevens vanwege kleine aantallen

Toelichting

Dit betreft het bruto maandloon (zie tabel 14), gedeeld door het contractuele aantal arbeidsuren per week in de baan waarin men het meeste aantal uren werkt, vermenigvuldigd met de factor 12/52.

Het gaat hier alleen om werkende schoolverlaters die niet doorstromen naar het voltijd dagonderwijs. 
Tabel 15B

Bruto uurloon van de werkende schoolverlaters per opleidingsrichting

Opleidingscluster

$\begin{array}{ccccccc}<6 & 6-9 & 9-12 & 12-15 & 15-18 & >=18 & \begin{array}{c}\text { gemid- } \\ \text { deld }\end{array} \quad \begin{array}{c}\text { Totaal } \\ N=100 \%\end{array} \\ \text { gld } & \text { gld } & \text { gld } & \text { gld } & \text { gld } & \text { gld } & \text { gld } \\ \% & \% & \% & \% & \% & \% & \end{array}$

\begin{tabular}{lrrrrrrrr}
\hline AVO & & & & & & & & \\
MAVO & 42 & 45 & 12 & 0 & 0 & 0 & 6,65 & 112 \\
HAVO & 20 & 45 & 28 & 8 & 0 & 0 & 8,11 & 91 \\
VWO & - & - & - & - & - & - & - & -
\end{tabular}

\section{VBO}

landbouw

bouwtechniek

mechanische techniek

elektrotechniek

motorvoertuigentechniek

consumptieve techniek

installatietechniek

grafische techniek

overig techniek

administratie

verkoop

handel

verzorging

uiterlijke verzorging

mode en kleding

overig

MBO-kort

landbouw

elektrotechniek

motorv. techniek

consumptieve techniek

werktuigbouw

overig techniek

(detail)handel

administratie

verzorging

overig dienstverlening/verzorging

overig

MBO-tussen en -lang

plantenteelt

veehouderij

levensmiddelentechnologie

bloemschikken

dierenverzorging

groene ruimte

overig landbouw

bouwkunde

elektrotechniek

werktuigbouwkunde

weg- en waterbouwkunde

motorvoertuigentechniek

mechanische techniek
44

13$$
\text { (3) }
$$

14

28

11

-

12

52

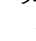$$
\text { - }
$$

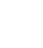$$
18
$$

38

$\begin{array}{rrrrr}3 & 0 & 1 & 7,16 & 26 \\ 3 & 0 & 0 & 7,96 & 118 \\ 0 & 4 & 4 & 7,19 & 79 \\ - & - & - & - & - \\ 0 & 0 & 0 & 6,46 & 79 \\ 1 & 0 & 0 & 8,47 & 61 \\ - & - & - & - & - \\ - & - & - & - & - \\ - & - & - & - & - \\ - & - & - & - & - \\ - & - & - & - & - \\ - & - & - & - & - \\ 5 & 0 & 1 & 7,10 & 62 \\ - & - & - & - & - \\ - & - & - & - & - \\ - & - & - & - & -\end{array}$

(n)

(n)


Tabel 15B (vervolg)

Bruto uurloon van de werkende schoolverlaters per opleidingsrichting

Opleidingscluster

$\begin{array}{cccccccc}<6 & 6-9 & 9-12 & 12-15 & 15-18 & >=18 & \begin{array}{c}\text { gemid- } \\ \text { deld }\end{array} & \begin{array}{c}\text { Totaal } \\ \text { (1) }=100 \%\end{array} \\ \text { gld } & \text { gld } & \text { gld } & \text { gld } & \text { gld } & \text { gld } & \text { gld } \\ \% & \% & \% & \% & \% & \% & \end{array}$

grafische techniek

proces- en laboratoriumtechniek

nautisch

mode \& kleding (techn)

overig techniek

administratie

secretariaat

commercieel

economisch-juridisch

vrije afstudeerrichting

toerisme en recreatie

logistiek

(detail)handel

horeca

overig economie

agogisch werk

verzorging

assistenten gezondheidszorg

mode \& kleding (verz)

activiteitenbegeleiding

facilitaire dienstverlening

uiterlijke verzorging

sociale arbeid

verpleging

overig dienstverlening/verzorging

overig

Totaal

15

5

$5-11$

34

$35 \quad 14$

$\begin{array}{ll}14,97 & 13 \\ 16,78 & 27\end{array}$

$\begin{array}{rrrrrrr}0 & 7 & 32 & 25 & 36 & 16,78 & 27 \\ - & - & - & - & - & - & -\end{array}$

$37 \quad 33$

$14 \quad 24$

$17 \quad 42$

$19 \quad 42$

$\begin{array}{ll}19 & 42 \\ 21 & 39\end{array}$

- $\quad-$

$16 \quad 35$

$\begin{array}{rr}16 & 35 \\ 5 & 36\end{array}$

- -

$20 \quad 40$

59

$15 \quad 50$

$\begin{array}{ll}15 & 50 \\ 18 & 33\end{array}$

$\begin{array}{ll}18 & 28\end{array}$

$\begin{array}{ll}7 & 17\end{array}$

$\begin{array}{rr}7 & 17 \\ 43 & 32\end{array}$

$\begin{array}{rr}43 & 32 \\ 3 & 15\end{array}$

$\begin{array}{rr}3 & 15 \\ 15 & 29\end{array}$

$\begin{array}{ll}15 & 29 \\ 15 & 48\end{array}$

$\begin{array}{rr}15 & 48 \\ 4 & 27 \\ 14 & 23\end{array}$

13

21

$31 \quad 5$

$25 \quad 10$

$23 \quad 10$

2310

$\begin{array}{rr}- & - \\ 28 & 19\end{array}$

$36 \quad 16$

9,85

26

$\begin{array}{rrrr}0 & 0 & 9,85 & 26 \\ 31 & 10 & 14,01 & 29\end{array}$

$\begin{array}{rrr}10 & 14,01 & 29 \\ 3 & 11,28 & 49\end{array}$

$3 \quad 11,24 \quad 66$

$5 \quad 11,34 \quad 36$

$\begin{array}{lrr}- & - & -\end{array}$

$\begin{array}{rrrrr}36 & 16 & 7 & 13,15 & 32 \\ - & - & - & - & \end{array}$

$\begin{array}{rrrrr}24 & 8 & 7 & 11,72 & 117\end{array}$

$\begin{array}{lllll}21 & 41 & 23 & 16,23 & 33\end{array}$

$\begin{array}{lllll}28 & 5 & 0 & 10,86 & 60\end{array}$

$\begin{array}{lllll}24 & 12 & 8 & 11,99 & 77\end{array}$

$\begin{array}{rrrrr}22 & 19 & 11 & 12,96 & 80 \\ 65 & 9 & 1 & 12,95 & 61\end{array}$

$\begin{array}{rrrrr}10 & 9 & 0 & 9,54 & 28\end{array}$

$\begin{array}{rrrrr}51 & 17 & 14 & 15,55 & 19\end{array}$

$\begin{array}{lrrrr}33 & 7 & 7 & 11,56 & 16\end{array}$

$\begin{array}{lllll}33 & 7 & 7 & 11,56 & 16 \\ 25 & 5 & 6 & 11,80 & 17\end{array}$

$\begin{array}{rrrrr}25 & 5 & 6 & 11,80 & 17 \\ 26 & 18 & 18 & 13,90 & 12 \\ 27 & 20 & 14 & 13,50 & 17\end{array}$

- = geen gegevens vanwege kleine aantallen

$\begin{array}{lllllll}27 & 25 & 18 & 9 & 5 & 10,35 & 2350\end{array}$

\section{Toelichting}

Dit betreft het bruto maandloon (zie tabel 14), gedeeld door het contractuele aantal arbeidsuren per week in de baan waarin men het meeste aantal uren werkt, vermenigvuldigd met de factor 12/52. Het gaat hier alleen om werkende schoolverlaters die niet doorstromen naar het voltijd dagonderwijs. 
Tabel 16A

Vereist opleidingsniveau van werkende schoolverlaters per opleidingscluster

\begin{tabular}{|c|c|c|c|c|}
\hline \multirow[t]{2}{*}{ Opleidingscluster } & \multirow{2}{*}{$\begin{array}{c}\text { lager } \\
\%\end{array}$} & \multirow{2}{*}{$\begin{array}{c}\text { zelfde } \\
\qquad \%\end{array}$} & \multirow{2}{*}{$\begin{array}{c}\text { hoger } \\
\%\end{array}$} & \multirow[t]{2}{*}{$\begin{array}{c}\text { Totaal } \\
N=100 \%\end{array}$} \\
\hline & & & & \\
\hline AVO & 35 & 62 & 3 & 299 \\
\hline MAVO & 21 & 73 & 6 & 135 \\
\hline HAVO & 49 & 51 & 0 & 107 \\
\hline VW0 & 41 & 59 & 0 & 57 \\
\hline VBO & 13 & 78 & 10 & 748 \\
\hline landbouw & 31 & 51 & 18 & 31 \\
\hline techniek & 12 & 77 & 11 & 513 \\
\hline economie & 11 & 81 & 8 & 87 \\
\hline dienstverlening/verzorging & 13 & 84 & 3 & 111 \\
\hline overig & - & - & - & - \\
\hline MBO-kort & 51 & 37 & 13 & 384 \\
\hline landbouw & 73 & 15 & 12 & 11 \\
\hline techniek & 33 & 59 & 8 & 154 \\
\hline economie & 58 & 22 & 20 & 161 \\
\hline dienstverlening/verzorging & 60 & 33 & 8 & 38 \\
\hline overig & - & - & - & - \\
\hline MBO-tussen en -lang & 36 & 63 & 0 & 1493 \\
\hline landbouw & 46 & 54 & 0 & 106 \\
\hline techniek & 35 & 65 & 0 & 419 \\
\hline economie & 28 & 72 & 1 & 515 \\
\hline dienstverlening/verzorging & 45 & 55 & 1 & 436 \\
\hline overig & - & - & - & - \\
\hline Totaal & 32 & 63 & 5 & 2924 \\
\hline
\end{tabular}

\section{Toelichting}

Vraag in de enquête: Welk soort opleiding werd minimaal voor je huidige baan vereist? Indien een lager opleidingsniveau werd vereist, spreekt men ook wel van onderbenutting. Bij een hoger vereist opleidingsniveau wordt wel van overbenutting gesproken.

Het gaat hier alleen om werkende schoolverlaters die niet doorstromen naar het voltijd dagonderwijs. 
Tabel 16B

Vereist opleidingsniveau van werkende schoolverlaters per opleidingsrichting

Opleidingsrichting lager

$\%$

\section{zelfde}

AVO

MAVO

HAVO

VWO

VBO

landbouw

bouwtechniek

mechanische techniek

elektrotechniek

motorvoertuigentechniek

consumptieve techniek

installatietechniek

grafische techniek

overig techniek

administratie

verkoop

handel

verzorging

uiterlijke verzorging

mode en kleding

overig

MBO-kort

landbouw

elektrotechniek

motorv. techniek

consumptieve techniek

werktuigbouw

overig techniek

(detail)handel

administratie

verzorging

overig dienstverlening/verzorging

overig

MBO-tussen en -lang

plantenteelt

veehouderij

levensmiddelentechnologie

bloemschikken

dierenverzorging

groene ruimte

overig landbouw

bouwkunde

elektrotechniek

werktuigbouwkunde

weg- en waterbouwkunde

motorvoertuigentechniek

mechanische techniek

grafische techniek
73

21

49

41

51

59

31

11

9

24

6

11

$-$

$-$

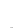

16

$-$

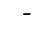

73

31

15

22

22

46

70

52

64

$-$

$-$

82
$\%$

hoger

Totaal

$\mathrm{N}=100 \%$

$\%$

135

107

57

31

140

93

70

94

75

$-$

$-$

75

2

-

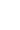

11

18

40

41

28

57

105

26

29

-

25

29

10

15

7

19

62

110

79

14

25

15 
Tabel 16B (vervolg)

Vereist opleidingsniveau van werkende schoolverlaters per opleidingsrichting

Opleidingsrichting

lager

zelfde

hoger

Totaal

$\%$

$\%$

proces- en laboratoriumtechniek

nautisch

mode \& kleding (techn)

34

$\%$

$\%$

$\mathrm{N}=100 \%$

overig techniek

administratie

secretariaat

commercieel

economisch-juridisch

vrije afstudeerrichting

toerisme en recreatie

logistiek

(detail)handel

horeca

overig economie

agogisch werk

verzorging

assistenten gezondheidszorg

mode \& kleding (verz)

activiteitenbegeleiding

facilitaire dienstverlening

uiterlijke verzorging

sociale arbeid

verpleging

overig dienstverlening/verzorging

overig

Totaal

$\%$

$66 \quad 1136$

57

42

58

79

82

83

17

17

$-$

$20 \quad 80$

80

85

85

56

78

64

59

54

64
45

45
69

23

34

52

56

36

34

40

65

83

44

-

21

37

3

144

36

72

101

115

75

31

28

21

21

14

21

- = geen gegevens vanwege kleine aantallen

63

5

2924

\section{Toelichting}

Vraag in de enquête: Welk soort opleiding werd minimaal voor je huidige baan vereist? Indien een lager opleidingsniveau werd vereist, spreekt men ook wel van onderbenutting. Bij een hoger vereist opleidingsniveau wordt wel van overbenutting gesproken.

Het gaat hier alleen om werkende schoolverlaters die niet doorstromen naar het voltijd dagonderwijs. 
Tabel 17A

Vereiste opleidingsrichting van werkende schoolverlaters per opleidingscluster

\begin{tabular}{|c|c|c|c|c|}
\hline Opleidingscluster & $\begin{array}{c}\text { eigen } \\
\text { richting } \\
\%\end{array}$ & $\begin{array}{c}\text { andere } \\
\text { richting } \\
\%\end{array}$ & $\begin{array}{c}\text { geen } \\
\text { richting } \\
\%\end{array}$ & $\begin{array}{c}\text { Totaal } \\
N=100 \%\end{array}$ \\
\hline AVO & 9 & 6 & 85 & 301 \\
\hline MAVO & 4 & 8 & 87 & 135 \\
\hline HAVO & 10 & 7 & 83 & 107 \\
\hline WW0 & 19 & 0 & 81 & 59 \\
\hline VBO & 39 & 7 & 54 & 714 \\
\hline landbouw & 24 & 6 & 70 & 29 \\
\hline techniek & 50 & 8 & 42 & 478 \\
\hline economie & 18 & 6 & 76 & 91 \\
\hline dienstverlening/verzorging & 12 & 5 & 83 & 109 \\
\hline overig & - & - & - & - \\
\hline MBO-kort & 40 & 8 & 52 & 382 \\
\hline landbouw & 30 & 6 & 64 & 11 \\
\hline techniek & 62 & 8 & 30 & 155 \\
\hline economie & 24 & 8 & 68 & 159 \\
\hline dienstverlening/verzorging & 34 & 4 & 62 & 41 \\
\hline overig & - & - & - & - \\
\hline MBO-tussen en -lang & 52 & 6 & 42 & 1504 \\
\hline landbouw & 50 & 8 & 42 & 107 \\
\hline techniek & 61 & 6 & 33 & 416 \\
\hline economie & 40 & 7 & 53 & 517 \\
\hline dienstverlening/verzorging & 59 & 4 & 37 & 446 \\
\hline overig & - & - & - & - \\
\hline Totaal & 43 & 7 & 51 & 2901 \\
\hline
\end{tabular}

Toelichting

Vraag in de enquête: Werd een speciale richting voor je huidige baan vereist? (bijv. elektrotechniek of verpleging)

Het gaat hier alleen om werkende schoolverlaters die niet doorstromen naar het voltijd dagonderwijs. 
Tabel 17B

Vereiste opleidingsrichting van werkende schoolverlaters per opleidingsrichting

Opleidingsrichting

\section{eigen \\ richting}

$\%$

AVO

MAVO

HAVO

VWO

VBO

landbouw

bouwtechniek

mechanische techniek

elektrotechniek

motorvoertuigentechniek

consumptieve techniek

installatietechniek

grafische techniek

overig techniek

administratie

verkoop

handel

verzorging

uiterlijke verzorging

mode en kleding

overig

MBO-kort

landbouw

elektrotechniek

motorv. techniek

consumptieve techniek

werktuigbouw

overig techniek

(detail)handel

administratie

verzorging

overig dienstverlening/verzorging

overig

MBO-tussen en -lang

plantenteelt

veehouderij

levensmiddelentechnologie

bloemschikken

dierenverzorging

groene ruimte

overig landbouw

bouwkunde

elektrotechniek

werktuigbouwkunde

weg- en waterbouwkunde

motorvoertuigentechniek

mechanische techniek

grafische techniek

4

10

19

24

59

43

-

48

53

$-$

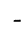

$-$

$-$

4

1

$-$ andere

richting

$\%$

geen

richting

Totaal

$\%$

$\mathrm{N}=100 \%$

87

83

81

135

8
7

0

59

70

35

43

-

45

38

-

-

-

84

84

11

18

40

40 
Tabel 17B (vervolg)

Vereiste opleidingsrichting van werkende schoolverlaters per opleidingsrichting

Opleidingsrichting

eigen
richting

$\%$

\section{andere \\ richting}

$\%$
Totaal

$\mathrm{N}=100 \%$

\author{
proces- en laboratoriumtechniek \\ nautisch \\ mode \& kleding (techn) \\ overig techniek \\ administratie \\ secretariaat \\ commercieel \\ economisch-juridisch \\ vrije afstudeerrichting \\ toerisme en recreatie \\ logistiek \\ (detail)handel \\ horeca \\ overig economie \\ agogisch werk \\ verzorging \\ assistenten gezondheidszorg \\ mode \& kleding (verz) \\ activiteitenbegeleiding \\ facilitaire dienstverlening \\ uiterlijke verzorging \\ sociale arbeid \\ verpleging \\ overig dienstverlening/verzorging \\ overig
}

\begin{tabular}{rrrr}
73 & 5 & 22 & 34 \\
- & - & - & - \\
31 & 2 & 66 & 33 \\
66 & 5 & 29 & 41 \\
55 & 4 & 41 & 65 \\
49 & 7 & 44 & 85 \\
26 & 8 & 66 & 43 \\
- & - & - & - \\
20 & 8 & 72 & 22 \\
50 & 8 & 41 & 38 \\
51 & 16 & 32 & 3 \\
24 & 8 & 68 & 147 \\
57 & 2 & 40 & 36 \\
49 & 9 & 42 & 69 \\
55 & 6 & 40 & 102 \\
66 & 3 & 31 & 118 \\
77 & 2 & 21 & 76 \\
30 & 3 & 68 & 34 \\
69 & 2 & 29 & 27 \\
33 & 3 & 64 & 21 \\
65 & 3 & 32 & 22 \\
33 & 9 & 58 & 14 \\
63 & 3 & 34 & 22 \\
- & - & - & - \\
- & - & - & - \\
\hline 43 & 7 & 51 & 2901
\end{tabular}

- = geen gegevens vanwege kleine aantallen

\section{Toelichting}

Vraag in de enquête: Werd een speciale richting voor je huidige baan vereist? (bijv. elektrotechniek of verpleging)

Het gaat hier alleen om werkende schoolverlaters die niet doorstromen naar het voltijd dagonderwijs. 
Tabel 18A

Soort dienstverband van de werkende schoolverlaters per opleidingscluster

Opleidingscluster

\begin{tabular}{l} 
\\
\hline AVO \\
MAVO \\
HAVO \\
WWO \\
VBO \\
landbouw \\
techniek \\
economie \\
dienstverlening/verzorging \\
overig
\end{tabular}

MBO-kort

landbouw

techniek

economie

dienstverlening/verzorging

overig

MBO-tussen en -lang

landbouw

techniek

economie

dienstverlening/verzorging

overig

Totaal

leer/werkovereenkomst uitzend-

bureau

14

10

17

16

7

8

7

8

2

-

13

14

8

19

12

-

12

8

18

13

5

11 loondienst

werkgever

$\%$

45

47

32

64

26

29

36

53

-

53

54

42

64

49

71

66

70

77

68

- = geen gegevens vanwege kleine aantallen

Toelichting

Het gaat hier alleen om werkende schoolverlaters die niet doorstromen naar het voltijd dagonderwijs. 


\begin{tabular}{|c|c|c|c|c|}
\hline $\begin{array}{c}\text { oproep- of } \\
\text { nul-uren } \\
\text { contract } \\
\%\end{array}$ & $\begin{array}{c}\text { werkervarings- } \\
\text { project } \\
\%\end{array}$ & $\begin{array}{c}\text { bedrijf } \\
\text { ouders/partner } \\
\%\end{array}$ & $\begin{array}{c}\text { eigen bedrijf/ } \\
\text { free-lance } \\
\%\end{array}$ & $\begin{array}{c}\text { Totaal } \\
\mathrm{N}=100 \%\end{array}$ \\
\hline 9 & 0 & 2 & 0 & 304 \\
\hline 4 & 0 & 2 & 0 & 138 \\
\hline 14 & 0 & 2 & 0 & 107 \\
\hline 10 & 0 & 0 & 0 & 59 \\
\hline 1 & 1 & 1 & 0 & 756 \\
\hline 1 & 1 & 0 & 1 & 30 \\
\hline 1 & 0 & 1 & 0 & 519 \\
\hline 2 & 4 & 0 & 0 & 88 \\
\hline 0 & 5 & 0 & 0 & 112 \\
\hline- & - & - & - & - \\
\hline 1 & 4 & 2 & 1 & 403 \\
\hline 7 & 6 & 8 & 1 & 12 \\
\hline 1 & 2 & 0 & 0 & 158 \\
\hline 1 & 5 & 4 & 2 & 173 \\
\hline 6 & 7 & 0 & 1 & 42 \\
\hline- & - & - & - & - \\
\hline 5 & 1 & 3 & 1 & 1527 \\
\hline 2 & 1 & 13 & 5 & 109 \\
\hline 1 & 1 & 3 & 1 & 423 \\
\hline 2 & 2 & 2 & 2 & 525 \\
\hline 11 & 1 & 0 & 1 & 453 \\
\hline- & - & - & - & - \\
\hline 4 & 2 & 2 & 1 & 2990 \\
\hline
\end{tabular}


Tabel 18B

Soort dienstverband van de werkende schoolverlaters per opleidingsrichting

Opleidingsrichting

leer/werk-

overeenkomst uitzend-

bureau

$\%$

10

loondienst

werkgever

$\%$

AVO
MAVO
HAVO
WWO

VBO

landbouw

bouwtechniek

mechanische techniek

elektrotechniek

motorvoertuigentechniek

consumptieve techniek

installatietechniek

grafische techniek

overig techniek

administratie

verkoop

handel

verzorging

uiterlijke verzorging

mode en kleding

overig

MBO-kort

landbouw

elektrotechniek

motorv. techniek

consumptieve techniek

werktuigbouw

overig techniek

(detail)handel

administratie

verzorging

overig dienstverlening/verzorging

overig

MBO-tussen en -lang

plantenteelt

veehouderij

levensmiddelentechnologie

bloemschikken

dierenverzorging

groene ruimte

overig landbouw

bouwkunde

elektrotechniek

werktuigbouwkunde

weg- en waterbouwkunde

motorvoertuigentechniek

mechanische techniek
17

16 


\begin{tabular}{|c|c|c|c|c|}
\hline $\begin{array}{c}\text { oproep- of } \\
\text { nul-uren } \\
\text { contract } \\
\%\end{array}$ & $\begin{array}{c}\text { werkervarings- } \\
\text { project } \\
\%\end{array}$ & $\begin{array}{c}\text { bedrijf } \\
\text { ouders/partner } \\
\%\end{array}$ & $\begin{array}{c}\text { eigen bedrijf/ } \\
\text { free-lance } \\
\%\end{array}$ & $\begin{array}{c}\text { Totaal } \\
\mathrm{N}=100 \%\end{array}$ \\
\hline 4 & 0 & 2 & 0 & 138 \\
\hline 14 & 0 & 2 & 0 & 107 \\
\hline 10 & 0 & 0 & 0 & 59 \\
\hline 1 & 1 & 0 & 1 & 30 \\
\hline 0 & 0 & 0 & 1 & 150 \\
\hline 0 & 0 & 3 & 0 & 90 \\
\hline 4 & 0 & 0 & 0 & 70 \\
\hline 0 & 0 & 0 & 0 & 91 \\
\hline 1 & 0 & 0 & 0 & 78 \\
\hline- & - & - & - & - \\
\hline- & - & - & - & - \\
\hline- & - & - & - & - \\
\hline- & - & - & - & - \\
\hline- & - & - & - & - \\
\hline- & - & - & - & - \\
\hline 0 & 5 & 0 & 0 & 74 \\
\hline- & - & - & - & - \\
\hline- & - & - & - & - \\
\hline- & - & - & - & - \\
\hline 7 & 6 & 8 & 1 & 12 \\
\hline 2 & 0 & 1 & 0 & 18 \\
\hline- & - & - & - & - \\
\hline 1 & 0 & 1 & 0 & 43 \\
\hline- & - & - & - & - \\
\hline 0 & 7 & 0 & 0 & 30 \\
\hline 0 & 5 & 9 & 2 & 62 \\
\hline 2 & 5 & 1 & 2 & 111 \\
\hline 9 & 10 & 0 & 2 & 31 \\
\hline- & - & - & - & - \\
\hline- & - & - & - & - \\
\hline 2 & 0 & 25 & 7 & 25 \\
\hline 2 & 1 & 20 & 5 & 31 \\
\hline 0 & 5 & 0 & 0 & 10 \\
\hline 2 & 2 & 2 & 8 & 15 \\
\hline 9 & 4 & 2 & 2 & 7 \\
\hline 1 & 1 & 2 & 0 & 19 \\
\hline- & - & - & - & - \\
\hline 0 & 0 & 15 & 1 & 62 \\
\hline 0 & 0 & 3 & 1 & 111 \\
\hline 3 & 2 & 1 & 0 & 84 \\
\hline 0 & 0 & 0 & 0 & 14 \\
\hline 0 & 0 & 0 & 1 & 25 \\
\hline - & - & - & - & - \\
\hline
\end{tabular}


Tabel 18B (vervolg)

Soort dienstverband van de werkende schoolverlaters per opleidingsrichting

\section{Opleidingsrichting}

proces- en laboratoriumtechniek

nautisch

mode \& kleding (techn)

overig techniek

administratie

secretariaat

commercieel

economisch-juridisch

vrije afstudeerrichting

toerisme en recreatie

logistiek

(detail)handel

horeca

overig economie

agogisch werk

verzorging

assistenten gezondheidszorg

mode \& kleding (verz)

activiteitenbegeleiding

facilitaire dienstverlening

uiterlijke verzorging

sociale arbeid

verpleging

overig dienstverlening/verzorging

overig

\section{leer/werk- overeenkomst}

$\%$

-

1

1

2

$-$

21

4

3

19

5

0

36

\section{uitzend- \\ bureau}

$\%$

10

42

-

22

21

20

22

13

23

8

9

8

5

11

7

3

5

4

5

9

1

23

5 loondienst werkgever

$\%$

78

53

77

63

76

71

69

73

84

86

79

88

77

56

58

88

90

83

73

87

66

48

Totaal

27

11

55

- = geen gegevens vanwege kleine aantallen

Toelichting

Het gaat hier alleen om werkende schoolverlaters die niet doorstromen naar het voltijd dagonderwijs. 


\begin{tabular}{|c|c|c|c|c|}
\hline $\begin{array}{l}\text { oproep- of } \\
\text { nul-uren } \\
\text { contract }\end{array}$ & $\begin{array}{c}\text { werkervarings- } \\
\text { project }\end{array}$ & $\begin{array}{c}\text { bedrijf } \\
\text { ouders/partner }\end{array}$ & $\begin{array}{l}\text { eigen bedrijf/ } \\
\text { free-lance }\end{array}$ & $\begin{array}{c}\text { Totaal } \\
N=100 \%\end{array}$ \\
\hline$\%$ & $\%$ & $\%$ & $\%$ & \\
\hline 2 & 2 & 3 & 3 & 15 \\
\hline 1 & 2 & 1 & 0 & 37 \\
\hline- & - & - & - & - \\
\hline 1 & 0 & 1 & 0 & 34 \\
\hline 0 & 0 & 0 & 5 & 38 \\
\hline 2 & 0 & 1 & 0 & 65 \\
\hline 1 & 2 & 2 & 1 & 86 \\
\hline 7 & 1 & 6 & 2 & 45 \\
\hline- & - & - & - & - \\
\hline 2 & 0 & 1 & 1 & 22 \\
\hline 4 & 0 & 0 & 1 & 38 \\
\hline 3 & 0 & 3 & 0 & 3 \\
\hline 3 & 1 & 3 & 4 & 150 \\
\hline 2 & 0 & 3 & 0 & 36 \\
\hline 0 & 11 & 0 & 0 & 71 \\
\hline 21 & 1 & 0 & 0 & 103 \\
\hline 17 & 1 & 0 & 1 & 120 \\
\hline 2 & 0 & 1 & 0 & 78 \\
\hline 1 & 2 & 0 & 1 & 35 \\
\hline 7 & 2 & 0 & 0 & 28 \\
\hline 0 & 0 & 0 & 0 & 21 \\
\hline 4 & 0 & 0 & 3 & 23 \\
\hline 4 & 4 & 0 & 4 & 14 \\
\hline 10 & 1 & 0 & 0 & 22 \\
\hline- & - & - & - & - \\
\hline- & - & - & - & - \\
\hline 4 & 2 & 2 & 1 & 2990 \\
\hline
\end{tabular}


Tabel 19A

Percentage werkende schoolverlaters met een vaste aanstelling per opleidingscluster

Opleidingscluster

vaste

aanstelling

AVO

MAVO

HAVO

VWO

VBO

landbouw

techniek

economie

dienstverlening/verzorging

overig

MBO-kort

landbouw

techniek

economie

dienstverlening/verzorging

overig

MBO-tussen en -lang

landbouw

techniek

economie

dienstverlening/verzorging

overig

Totaal
$\%$

Totaal

$\mathrm{N}=100 \%$

\section{4}

132

102

59

709

479

85

110

380

$\begin{array}{lr}61 & 10\end{array}$

$59-154$

$51-160$

$67-38$

$67-1434$

$65 \quad 89$

$68 \quad 397$

497

$68-435$

- = geen gegevens vanwege kleine aantallen

Toelichting

Onder een 'vaste aanstelling' wordt hier verstaan een vaste baan of proeftijd voor een vaste baan. Het gaat hier alleen om de in loondienst werkende schoolverlaters die niet doorstromen naar het voltijd dagonderwijs. 
Tabel 19B

Percentage werkende schoolverlaters met een vaste aanstelling per opleidingsrichting

Opleidingsrichting

vaste

Totaal

aanstelling

$\mathrm{N}=100 \%$

$\%$

AVO

MAVO

HAVO

VWO

VBO

landbouw

bouwtechniek

mechanische techniek

elektrotechniek

motorvoertuigentechniek

consumptieve techniek

installatietechniek

grafische techniek

overig techniek

administratie

verkoop

handel

verzorging

uiterlijke verzorging

mode en kleding

overig

MBO-kort

landbouw

elektrotechniek

motorv. techniek

consumptieve techniek

werktuigbouw

overig techniek

(detail)handel

administratie

verzorging

overig dienstverlening/verzorging

overig

MBO-tussen en -lang

plantenteelt

veehouderij

levensmiddelentechnologie

bloemschikken

dierenverzorging

groene ruimte

overig landbouw

bouwkunde

elektrotechniek

werktuigbouwkunde

weg- en waterbouwkunde

motorvoertuigentechniek

mechanische techniek

grafische techniek 
Tabel 19B (vervolg)

Percentage werkende schoolverlaters met een vaste aanstelling per opleidingsrichting

Opleidingsrichting

\begin{tabular}{cc}
$\begin{array}{c}\text { vaste } \\
\text { aanstelling } \\
\%\end{array}$ & $\begin{array}{c}\text { Totaal } \\
\mathrm{N}=100 \%\end{array}$ \\
\hline
\end{tabular}

proces- en laboratoriumtechniek

53

36

nautisch

mode \& kleding (techn)

overig techniek

administratie

secretariaat

commercieel

economisch-juridisch

vrije afstudeerrichting

toerisme en recreatie

logistiek

(detail)handel

horeca

overig economie

agogisch werk

verzorging

assistenten gezondheidszorg

mode \& kleding (verz)

activiteitenbegeleiding

facilitaire dienstverlening

uiterlijke verzorging

sociale arbeid

verpleging

overig dienstverlening/verzorging

overig

Totaal

- = geen gegevens vanwege kleine aantallen

\section{Toelichting}

Onder een 'vaste aanstelling' wordt hier verstaan een vaste baan of proeftijd voor een vaste baan. Het gaat hier alleen om de in loondienst werkende schoolverlaters die niet doorstromen naar het voltijd dagonderwijs. 
Tabel 20A

Wekelijkse arbeidsduur van werkende schoolverlaters per opleidingscluster

\begin{tabular}{|c|c|c|c|c|c|}
\hline Opleidingscluster & $\begin{array}{c}<=19 \\
\text { uur } \\
\%\end{array}$ & $\begin{array}{c}20-34 \\
\operatorname{uur} \\
\%\end{array}$ & $\begin{array}{c}\text { >=35 } \\
\text { uur } \\
\%\end{array}$ & $\begin{array}{l}\text { gemid- } \\
\text { deld }\end{array}$ & $\begin{array}{c}\text { Totaal } \\
N=100 \%\end{array}$ \\
\hline AVO & 5 & 38 & 57 & 34 & 308 \\
\hline MAVO & 2 & 47 & 51 & 33 & 132 \\
\hline HAVO & 9 & 25 & 66 & 34 & 112 \\
\hline WwO & 6 & 41 & 54 & 35 & 61 \\
\hline VBO & 3 & 54 & 43 & 34 & 747 \\
\hline landbouw & 6 & 53 & 41 & 32 & 33 \\
\hline techniek & 2 & 53 & 45 & 35 & 506 \\
\hline economie & 0 & 68 & 32 & 31 & 87 \\
\hline dienstverlening/verzorging & 5 & 48 & 47 & 32 & 114 \\
\hline overig & - & - & - & - & - \\
\hline MBO-kort & 3 & 34 & 63 & 35 & 400 \\
\hline landbouw & 6 & 30 & 64 & 35 & 12 \\
\hline techniek & 1 & 38 & 61 & 36 & 161 \\
\hline economie & 3 & 28 & 69 & 36 & 168 \\
\hline dienstverlening/verzorging & 11 & 46 & 43 & 31 & 42 \\
\hline overig & - & - & - & - & - \\
\hline MBO-tussen en -lang & 3 & 23 & 74 & 36 & 1508 \\
\hline landbouw & 4 & 18 & 78 & 38 & 107 \\
\hline techniek & 2 & 10 & 88 & 38 & 424 \\
\hline economie & 1 & 19 & 80 & 37 & 525 \\
\hline dienstverlening/verzorging & 7 & 41 & 52 & 33 & 435 \\
\hline overig & - & - & - & - & - \\
\hline Totaal & 3 & 34 & 63 & 35 & 2955 \\
\hline
\end{tabular}

\section{Toelichting}

Dit betreft het contractuele aantal arbeidsuren in de baan waarin men het meeste aantal uren werkt, exclusief overwerk.

Het gaat hier alleen om werkende schoolverlaters die niet doorstromen naar het voltijd dagonderwijs. 
Tabel 20B

Wekelijkse arbeidsduur van werkende schoolverlaters per opleidingsrichting

Opleidingsrichting

$\begin{array}{cc}<=19 & 20-34 \\ \text { uur } & \text { uur } \\ \% & \%\end{array}$

AVO

MAVO

HAVO

VW0

VBO

landbouw

bouwtechniek

mechanische techniek

elektrotechniek

motorvoertuigentechniek

consumptieve techniek

installatietechniek

grafische techniek

overig techniek

administratie

verkoop

handel

verzorging

uiterlijke verzorging

mode en kleding

overig

MBO-kort

landbouw

elektrotechniek

motorv. techniek

consumptieve techniek

werktuigbouw

overig techniek

(detail)handel

administratie

verzorging

overig dienstverlening/verzorging overig

MBO-tussen en -lang

plantenteelt

veehouderij

levensmiddelentechnologie

bloemschikken

dierenverzorging

groene ruimte

overig landbouw

bouwkunde

elektrotechniek

werktuigbouwkunde

weg- en waterbouwkunde

motorvoertuigentechniek

mechanische techniek

grafische techniek
47

25

41

6

6

53

51

45

40

73

66

gemid-

deld

Totaal

uur

$\%$

$\mathrm{N}=100 \%$

$\begin{array}{rrr}51 & 33 & 132 \\ 66 & 34 & 107 \\ 54 & 35 & 61\end{array}$

132

61

41

33

49

(2)

\section{.}


Tabel 20B (vervolg)

Wekelijkse arbeidsduur van werkende schoolverlaters per opleidingsrichting

\begin{tabular}{|c|c|c|c|c|c|}
\hline Opleidingsrichting & $\begin{array}{c}<=19 \\
\text { uur } \\
\%\end{array}$ & $\begin{array}{c}20-34 \\
\text { uur } \\
\%\end{array}$ & $\begin{array}{c}\text { >=35 } \\
\text { uur } \\
\%\end{array}$ & $\begin{array}{l}\text { gemid- } \\
\text { deld }\end{array}$ & $\begin{array}{c}\text { Totaal } \\
N=100 \%\end{array}$ \\
\hline proces- en laboratoriumtechniek & 0 & 12 & 88 & 38 & 37 \\
\hline nautisch & - & - & - & - & - \\
\hline mode \& kleding (techn) & 6 & 39 & 54 & 33 & 34 \\
\hline overig techniek & 3 & 10 & 88 & 41 & 40 \\
\hline administratie & 0 & 12 & 88 & 38 & 65 \\
\hline secretariaat & 2 & 17 & 82 & 37 & 86 \\
\hline commercieel & 1 & 16 & 83 & 37 & 44 \\
\hline economisch-juridisch & - & - & - & - & - \\
\hline vrije afstudeerrichting & 0 & 21 & 79 & 36 & 22 \\
\hline toerisme en recreatie & 0 & 12 & 88 & 38 & 38 \\
\hline logistiek & 0 & 6 & 94 & 39 & 3 \\
\hline (detail)handel & 2 & 30 & 68 & 35 & 148 \\
\hline horeca & 2 & 14 & 84 & 37 & 36 \\
\hline overig economie & 1 & 15 & 84 & 37 & 73 \\
\hline agogisch werk & 14 & 44 & 43 & 31 & 99 \\
\hline verzorging & 5 & 41 & 54 & 33 & 111 \\
\hline assistenten gezondheidszorg & 2 & 31 & 67 & 35 & 77 \\
\hline mode \& kleding (verz) & 1 & 41 & 58 & 34 & 35 \\
\hline activiteitenbegeleiding & 11 & 59 & 29 & 27 & 27 \\
\hline facilitaire dienstverlening & 4 & 48 & 47 & 32 & 21 \\
\hline uiterlijke verzorging & 6 & 57 & 36 & 30 & 22 \\
\hline sociale arbeid & 4 & 32 & 64 & 34 & 14 \\
\hline verpleging & 4 & 29 & 66 & 35 & 21 \\
\hline overig dienstverlening/verzorging & - & - & - & - & - \\
\hline overig & - & - & - & - & - \\
\hline Totaal & 3 & 34 & 63 & 35 & 2955 \\
\hline
\end{tabular}

- = geen gegevens vanwege kleine aantallen

\section{Toelichting}

Dit betreft het contractuele aantal arbeidsuren in de baan waarin men het meeste aantal uren werkt, exclusief overwerk.

Het gaat hier alleen om werkende schoolverlaters die niet doorstromen naar het voltijd dagonderwijs. 
Tabel 21A

Belangrijkste bedrijfsgroepen waarin schoolverlaters werkzaam zijn per opleidingscluster

MAVO

Gespec. detailh. voed.-/genotmid. in winkel 12

Restaurants/cafetaria's/snackbars ed $\quad 12$

Gezondheidszorg $\quad 8$

Niet-gespec. detailh. in winkel

Ov. dienstverlening 6

Ov. gespec. detailh. in winkel

HAVO

Gezondheidszorg

Niet-gespec. detailh. in winkel

Ov. gespec. detailh. in winkel

Geldscheppende financ. instell.

Vervaard. kleding/-toebehoren (excl. leer)

12
6
6
6

WWO

Rechtsk. dienstverl./account./belastingconsul./holdings ed 12

Gespec. detailh. voed.-/genotmid. in winkel 11

Ov. gespec. detailh. in winkel $\quad 8$

Handel auto-onderd./-accessoir. $\quad 7$

Geldscheppende financ. instell.

Overheidsdienst. $\quad 7$

Hotels/pensions/conferentie-oorden $\quad 6$

Kampeerterreinen/ov. voorzien. recreat. verblijf n.e.g. $\quad 6$

Restaurants/cafetaria's/snackbars ed $\quad 6$

Niet-gespec. detailh. in winkel 5

VBO landbouw

Niet-gespec. detailh. in winkel $\quad 15$

$\begin{array}{ll}\text { Ov. gespec. detailh. in winkel } & 15\end{array}$

$\begin{array}{ll}\text { Akker-/tuinbouw } & 14\end{array}$

Dienstverl. tbv landb. (excl. veterin.dienst.) 12

\section{VBO techniek}

Burgerl./utilit:;grond-/water-/wegenb. (excl. grondverz.) 17

Handel in/repar. auto's (1) 15

Bouwinstallatie $\quad 8$

Vervaard. mach./appar. $\quad 6$

Afwerken gebouwen $\quad 6$

VBO economie

Niet-gespec. detailh. in winkel 18

Gespec. detailh. voed.-/genotmid. in winkel 14

Ov. gespec. detailh. in winkel

Grooth. voedings-/genotmid. 6

$\begin{array}{ll}\text { Restaurants/cafetaria's/snackbars ed } & 6\end{array}$

VBO dienstverlening/verzorging

Ov. gespec. detailh. in winkel $\quad 16$

Niet-gespec. detailh. in winkel $\quad 16$ 
Tabel 21A (vervolg)

Belangrijkste bedrijfsgroepen waarin schoolverlaters werkzaam zijn per opleidingscluster

$\%$

Welzijnszorg

Gespec. detailh. voed.-/genotmid. in winkel

Ov. dienstverlening

\section{MBO-kort landbouw}

Ov. gespec. detailh. in winkel

Akker-/tuinbouw

Dienstverl. tbv landb. (excl. veterin.dienst.)

Niet-gespec. detailh. in winkel

Veterinaire diensten

Ov. dienstverlening

Reiniging gebouwen/transportmid. ed

Sport

MBO-kort techniek

Handel in/repar. auto's (1)

Restaurants/cafetaria's/snackbars ed

Bouwinstallatie

Burgerl./utilit.;grond-/water-/wegenb. (excl. grondverz.)

Hotels/pensions/conferentie-oorden

\section{MBO-kort economie}

Ov. gespec. detailh. in winkel

Niet-gespec. detailh. in winkel

Gespec. detailh. voed.-/genotmid. in winkel

Overheidsdienst.

MBO-kort dienstverlening/verzorging

Welzijnszorg

Ov. dienstverlening

Gezondheidszorg

Ov. gespec. detailh. in winkel

Akker-/tuinbouw

\section{MBO landbouw}

Akker-/tuinbouw $\quad 18$

Ov. gespec. detailh. in winkel

Dienstverl. tbv landb. (excl. veterin.dienst.)

Fokken/houden dieren

\section{MBO techniek}

Burgerl./utilit.;grond-/water-/wegenb. (excl. grondverz.) Bouwinstallatie

Handel in/repar. auto's (1)

Ov. gespec. detailh. in winkel

Architecten-/ingenieurs-/ov. techn.ontw.-/teken-/adviesbur. 
Tabel 21A (vervolg)

Belangrijkste bedrijfsgroepen waarin schoolverlaters werkzaam zijn per opleidingscluster

Niet-gespec. detailh. in winkel

6

Hotels/pensions/conferentie-oorden

$\mathrm{MBO}$ dienstverlening/verzorging

Welzijnszorg

Gezondheidszorg

Ov. gespec. detailh. in winkel

Detailh. farmac./med. art./parfum/cosmet. in winkel

geen gegevens vanwege kleine aantallen:

VBO overig

MBO-kort overig

$\mathrm{MBO}$ overig

\section{Toelichting}

De bedrijven waarin de schoolverlaters werkzaam zijn, zijn geclassificeerd volgens de in 1993 grondig herziene Standaard Bedrijfs Indeling van het CBS. Op het hier gepresenteerde niveau van bedriffsgroepen worden in totaal 211 categorieën onderscheiden.

In de tabel zijn alleen die bedrijfsgroepen weergegeven, waarin ten minste $5 \%$ van de schoolverlaters werkzaam zijn.

Het gaat hier alleen om werkende schoolverlaters die niet doorstromen naar het voltijd dagonderwijs. 
MAVO

Gespec. detailh. voed.-/genotmid. in winkel $\quad 12$

Restaurants/cafetaria's/snackbars ed 12

Gezondheidszorg

Niet-gespec. detailh. in winkel

Ov. dienstverlening

Ov. gespec. detailh. in winkel

HAVO

Gezondheidszorg

Niet-gespec. detailh. in winkel

Ov. gespec. detailh. in winkel

Geldscheppende financ. instell.

Vervaard. kleding/-toebehoren (excl. leer)

WWO

Rechtsk. dienstverl./account./belastingconsul./holdings ed 12

Gespec. detailh. voed.-/genotmid. in winkel 11

Ov. gespec. detailh. in winkel $\quad 8$

Handel auto-onderd./-accessoir.

Geldscheppende financ. instell.

Overheidsdienst. $\quad 7$

Hotels/pensions/conferentie-oorden

Kampeerterreinen/ov. voorzien. recreat. verblijf n.e.g.

Restaurants/cafetaria's/snackbars ed

Niet-gespec. detailh. in winkel

VBO landbouw

Niet-gespec. detailh. in winkel

Ov. gespec. detailh. in winkel

Akker-/tuinbouw

Dienstverl. tbv landb. (excl. veterin.dienst.)

VBO bouwtechniek

Burgerl./utilit.;grond-/water-/wegenb. (excl. grondverz.) Afwerken gebouwen

Vervaard. meubels

VBO mechanische techniek

Vervaard. mach./appar.

Burgerl./utilit.;grond-/water-/wegenb. (excl. grondverz.)

Handel in/repar. auto's (1)

Expedit./cargad./bevracht.;weging/meting

VBO motorvoertuigentechniek

Handel in/repar. auto's (1)

Burgerl./utilit.;grond-/water-/wegenb. (excl. grondverz.) 
Tabel 21B (vervolg)

Belangrijkste bedrijfsgroepen waarin schoolverlaters werkzaam zijn per opleidingsrichting

$\%$

VBO consumptieve techniek

Gespec. detailh. voed.-/genotmid. in winkel

Hotels/pensions/conferentie-oorden 19

Restaurants/cafetaria's/snackbars ed 18

Vervaard. ov. voedingsmid.

VBO verzorging

Welzijnszorg

Ov. gespec. detailh. in winkel

Niet-gespec. detailh. in winkel

Gespec. detailh. voed.-/genotmid. in winkel

Ov. dienstverlening

MBO-kort landbouw

Ov. gespec. detailh. in winkel

Akker-/tuinbouw

Dienstverl. tbv landb. (excl. veterin.dienst.)

Niet-gespec. detailh. in winkel

Veterinaire diensten

Ov. dienstverlening

Reiniging gebouwen/transportmid. ed

Sport

MBO-kort elektrotechniek

Bouwinstallatie

Vervaard. mach./appar.

Ov. gespec. detailh. in winkel

Vervaard. kantoormachines/computers

Ov. eerste verwerking ijzer/staal

Vervaard. ov. goederen n.e.g.

Benzineservicestations

Reiniging gebouwen/transportmid. ed

MBO-kort motorv. techniek

Handel in/repar. auto's (1)

Expedit./cargad./bevracht.;weging/meting

MBO-kort consumptieve techniek

Restaurants/cafetaria's/snackbars ed

Hotels/pensions/conferentie-oorden

Welzijnszorg

Gespec. detailh. voed.-/genotmid. in winkel

Niet-gespec. detailh. in winkel

Overheidsdienst.

MBO-kort overig techniek

Burgerl./utilit:;grond-/water-/wegenb. (excl. grondverz.) 23

Bouwinstallatie

Visserij/kweken vis/schaaldieren 
Tabel 21B (vervolg)

Belangrijkste bedrijfsgroepen waarin schoolverlaters werkzaam zijn per opleidingsrichting

Drukkerijen/aanverwante activ.

Vervaard. meubels

MBO-kort (detail)handel

Ov. gespec. detailh. in winkel

Niet-gespec. detailh. in winkel

Gespec. detailh. voed.-/genotmid. in winkel

Handel in/repar. auto's (1)

Detailh. farmac./med. art./parfum/cosmet. in winkel

Restaurants/cafetaria's/snackbars ed

Overheidsdienst.

MBO-kort administratie

Niet-gespec. detailh. in winkel

Ov. gespec. detailh. in winkel

Overheidsdienst.

$\mathrm{MBO}-$ kort verzorging

Welzijnszorg

Gezondheidszorg

Restaurants/cafetaria's/snackbars ed

MBO plantenteelt

Akker-/tuinbouw

Dienstverl. tbv landb. (excl. veterin.dienst.)

Ov. gespec. detailh. in winkel

$M B O$ veehouderij

Fokken/houden dieren

Dienstverl. tbv landb. (excl. veterin.dienst.)

Ov. gespec. detailh. in winkel

\section{MBO levensmiddelentechnologie}

Vervaard. zuivelprodukten

Vervaard. voedingsmiddelen/dranken

Vervaard. ov. voedingsmid.

Groente-/fruitverwerking

Vervaard. dranken

Slachterijen/vleesverwerking

Niet-gespec. detailh. in winkel

MBO bloemschikken

Ov. gespec. detailh. in winkel

$\mathrm{MBO}$ dierenverzorging

Veterinaire diensten

Ov. gespec. detailh. in winkel

Niet-gespec. detailh. in winkel

Fokken/houden dieren 
Tabel 21B (vervolg)

Belangrijkste bedrijfsgroepen waarin schoolverlaters werkzaam zijn per opleidingsrichting

MBO groene ruimte

Dienstverl. tbv landb. (excl. veterin.dienst.) 45

Ov. gespec. detailh. in winkel

Burgerl//utilit:;grond-/water-/wegenb. (excl. grondverz.)

Akker-/tuinbouw

Architecten-/ingenieurs-/ov. techn.ontw.-/teken-/adviesbur.

$\mathrm{MBO}$ bouwkunde

Burgerl./utilit.;grond-/water-/wegenb. (excl. grondverz.)

MBO elektrotechniek

Bouwinstallatie

Ov. gespec. detailh. in winkel

$M B O$ werktuigbouwkunde

Vervaard. mach./appar.

Vervaard. glas/glaswerk

Overheidsdienst.

Burgerl./utilit:;grond-/water-/wegenb. (excl. grondverz.)

Bouwinstallatie

Handel in/repar. auto's (1)

Architecten-/ingenieurs-/ov. techn.ontw.-/teken-/adviesbur.

$\mathrm{MBO}$ weg- en waterbouwkunde

Burgerl./utilit.;grond-/water-/wegenb. (excl. grondverz.)

Architecten-/ingenieurs-/ov. techn.ontw.-/teken-/adviesbur.

Ov. gespec. detailh. in winkel

Openbaar bestuur

MBO motorvoertuigentechniek

Handel in/repar. auto's (1)

Bouwinstallatie

Vervaard. zeep-,was-,reinig.-/onderhoudsmid.,parfum/cosmet.

Vervaard. prod. voor bouw uit gebakken klei

Oppervlaktebehandeling/ov. metaalbewerking

MBO grafische techniek

Drukkerijen/aanverwante activ.

Uitgeverijen

MBO proces- en laboratoriumtechniek

Gezondheidszorg

Vervaard. chem. prod.

Vervaard. prod. kunststof

Vervaard. farmac. prod.

Grooth. mach./appar./toebehoren 
Tabel 21B (vervolg)

Belangrijkste bedrijfsgroepen waarin schoolverlaters werkzaam zijn per opleidingsrichting

$\%$

Natuursteenbewerking

Oppervlaktebehandeling/ov. metaalbewerking

MBO mode \& kleding (techn)

Ov. gespec. detailh. in winkel

Vervaard. kleding/-toebehoren (excl. leer)

Niet-gespec. detailh. in winkel

Grooth. ov. consumentenart.

Ov. dienstverlening

$M B O$ overig techniek

Handel in/repar. auto's (1)

Visserij/kweken vis/schaaldieren

Bouwinstallatie

Grooth. mach./appar./toebehoren

Niet-gespec. detailh. in winkel

Gezondheidszorg

\section{MBO administratie}

Rechtsk. dienstverl./account./belastingconsul./holdings ed Verzekeringsw./pensioenfonds. (excl. verpl. soc.verzek.) Activ. verzekeringsw./pensioenfonds.

Niet-gespec. detailh. in winkel

Burgerl./utilit.;grond-/water-/wegenb. (excl. grondverz.)

Geldscheppende financ. instell.

\section{MBO secretariaat}

Rechtsk. dienstverl./account./belastingconsul./holdings ed Geldscheppende financ. instell.

Gezondheidszorg

Burgerl./utilit.;grond-/water-/wegenb. (excl. grondverz.)

\section{MBO commercieel}

Geldscheppende financ. instell.

Activ. verzekeringsw./pensioenfonds.

Niet-gespec. detailh. in winkel

Gespec. detailh. voed.-/genotmid. in winkel

Ov. gespec. detailh. in winkel

Grooth. mach./appar./toebehoren

\section{$M B O$ vrije afstudeerrichting}

Geldscheppende financ. instell.

Bemid. in/beheer onroerend goed

Ov. gespec. detailh. in winkel

Rechtsk. dienstverl./account./belastingconsul./holdings ed

Activ. verzekeringsw./pensioenfonds.

Openbaar bestuur

Overheidsdienst. 
Tabel 21B (vervolg)

Belangrijkste bedrijfsgroepen waarin schoolverlaters werkzaam zijn per opleidingsrichting

$\%$

\section{MBO toerisme en recreatie}

Reisorgan./-bemid.;informatieverstrek. op gebied toerisme

Hotels/pensions/conferentie-oorden

Kampeerterreinen/ov. voorzien. recreat. verblijf n.e.g.

Vervoer door lucht

MBO logistiek

Expedit./cargad./bevracht.,weging/meting

Milieudienstverlening

Vervaard. prod. beton/cement/gips

Vervaard. med. appar./instrum./orthop./prothese-art.

Bouwinstallatie

Ov. gespec. grooth./grooth. met een alg. assort.

Ov. gespec. detailh. in winkel

Grooth./handelsbemid. (niet auto's/motorfiets.)

Niet-gespec. detailh. in winkel

Onderhoud/repar. computers/kantoormach.

MBO (detail)handel

Ov. gespec. detailh. in winkel

Niet-gespec. detailh. in winkel

Gespec. detailh. voed.-/genotmid. in winkel

Detailh. farmac./med. art./parfum/cosmet. in winkel

MBO horeca

Hotels/pensions/conferentie-oorden

\section{MBO overig economie}

Rechtsk. dienstverl./account./belastingconsul./holdings ed Ov. gespec. detailh. in winkel

Expedit./cargad./bevracht.;weging/meting

Activ. verzekeringsw./pensioenfonds.

Openbaar bestuur

\section{$M B O$ agogisch werk}

Welzijnszorg

Gezondheidszorg

$M B O$ verzorging

Welzijnszorg

Gezondheidszorg

$\mathrm{MBO}$ assistenten gezondheidszorg

Gezondheidszorg 
Tabel 21B (vervolg)

Belangrijkste bedrijfsgroepen waarin schoolverlaters werkzaam zijn per opleidingsrichting

$\%$

MBO mode en kleding (verz)

Ov. gespec. detailh. in winkel

65

Niet-gespec. detailh. in winkel

Bemid. in/beheer onroerend goed

MBO activiteitenbegeleiding

Welzijnszorg

Gezondheidszorg

MBO facilitaire dienstverlening

Niet-gespec. detailh. in winkel

Welzijnszorg

Gezondheidszorg

Hotels/pensions/conferentie-oorden

Kantines/catering

Restaurants/cafetaria's/snackbars ed

Reiniging gebouwen/transportmid. ed

Vervaard. kleding/-toebehoren (excl. leer)

$M B O$ uiterlijke verzorging

Ov. dienstverlening

Detailh. farmac./med. art./parfum/cosmet. in winkel

Ov. gespec. detailh. in winkel

Niet-gespec. detailh. in winkel

MBO sociale arbeid

Openbaar bestuur

Grooth. mach./appar./toebehoren

Uitzendbur/uitleenbedr./arbeidsbemid./testen/werven/select.

Niet-gespec. detailh. in winkel

Ov. gespec. detailh. in winkel

Overheidsdienst.

Welzijnszorg

\section{$M B O$ verpleging}

Welzijnszorg

Gezondheidszorg

geen gegevens vanwege kleine aantallen:

VBO elektrotechniek

VBO installatietechniek

VBO grafische techniek

VBO overig techniek

VBO administratie

VBO verkoop

VBO handel

VBO uiterlijke verzorging

VBO mode en kleding

VBO overig 
Tabel 21B (vervolg)

Belangrijkste bedrijfsgroepen waarin schoolverlaters werkzaam zijn per opleidingsrichting

$\%$

MBO-kort werktuigbouw

MBO-kort overig dienstverlening/verzorging

MBO-kort overig

MBO overig landbouw

MBO mechanische techniek

MBO nautisch

MBO economisch-juridisch

$\mathrm{MBO}$ overig dienstverlening/verzorging

MBO overig

\section{Toelichting}

De bedrijven waarin de schoolverlaters werkzaam zijn, zijn geclassificeerd volgens de in 1993 grondig herziene Standaard Bedrijfs Indeling van het CBS. Op het hier gepresenteerde niveau van bedrijfsgroepen worden in totaal 211 categorieën onderscheiden.

In de tabel zijn alleen die bedrijfsgroepen weergegeven, waarin ten minste $5 \%$ van de schoolverlaters werkzaam zijn.

Het gaat hier alleen om werkende schoolverlaters die niet doorstromen naar het voltijd dagonderwijs. 
MAVO

Lagere verkoopberoepen $\quad 22$

$\begin{array}{ll}\text { Elementaire beroepen } & 18\end{array}$

Lagere alg. verzorgende beroepen ed 16

$\begin{array}{lc}\text { Lagere bouwkundige beroepen } & 6\end{array}$

HAVO

$\begin{array}{ll}\text { Elementaire beroepen } & 19\end{array}$

Lagere (para)medische beroepen $\quad 18$

Lagere verkoopberoepen $\quad 14$

$\begin{array}{lr}\text { Middelbare commerciele beroepen ed } & 8\end{array}$

Lagere administratieve beroepen $\quad 8$

Lagere bouwkundige beroepen $\quad 7$

Lagere technische beroepen neg $\quad 6$

Lagere alg. verzorgende beroepen ed $\quad 6$

VWO

Lagere verkoopberoepen $\quad 27$

Middelbare administatieve beroepen (excl. automat. ed) ed 15

Lagere alg. verzorgende beroepen ed 14

Middelbare commerciele beroepen ed 10

Hogere administratieve beroepen (excl. automat. ed) 9

Lagere administratieve beroepen $\quad 9$

$\begin{array}{ll}\text { Middelbare beveiligingsberoepen } & 7\end{array}$

\section{VBO landbouw}

Lagere agrarische beroepen $\quad 34$

$\begin{array}{ll}\text { Lagere verkoopberoepen } & 19\end{array}$

$\begin{array}{ll}\text { Elementaire beroepen } & 18\end{array}$

$\begin{array}{ll}\text { Lagere alg. verzorgende beroepen ed } & 7\end{array}$

VBO techniek

Lagere bouwkundige beroepen $\quad 31$

Elementaire beroepen $\quad 13$

Lagere werktuigbouwkundige beroepen ed 13

$\begin{array}{ll}\text { Lagere metaalkundige beroepen } & 9 \\ \text { Lagere alg. verzorgende beroepen ed } & 6\end{array}$

\section{VBO economie}

$\begin{array}{ll}\text { Lagere verkoopberoepen } & 34\end{array}$

Elementaire beroepen $\quad 21$

Lagere administratieve beroepen $\quad 19$

Lagere alg. verzorgende beroepen ed $\quad 8$

VBO dienstverlening/verzorging

Lagere verkoopberoepen $\quad 42$

Lagere alg. verzorgende beroepen ed 16

$\begin{array}{lr}\text { Elementaire beroepen } & 14\end{array}$

Lagere (para)medische beroepen 9 
Tabel 22A (vervolg)

Belangrijkste beroepsgroepen waarin schoolverlaters werkzaam zijn per opleidingscluster

MBO-kort landbouw

Lagere agrarische beroepen 31

Lagere verkoopberoepen

Elementaire beroepen

Lagere technisch-agrarische beroepen

MBO-kort techniek

Middelbare werktuigbouwkundige beroepen ed

Lagere alg. verzorgende beroepen ed

Middelbare bouwkundige beroepen

Lagere metaalkundige beroepen

Middelbare elektrotechnische beroepen (excl. automat. ed)

Elementaire beroepen

MBO-kort economie

Lagere administratieve beroepen

Lagere verkoopberoepen

Middelbare administatieve beroepen (excl. automat. ed) ed

Elementaire beroepen

MBO-kort dienstverlening/verzorging

Elementaire beroepen

Middelbare alg. verzorgende beroepen

Lagere alg. verzorgende beroepen ed

Lagere (para)medische beroepen

Lagere verkoopberoepen

Lagere administratieve beroepen

Lagere agrarische beroepen

MBO landbouw

Lagere agrarische beroepen

Lagere verkoopberoepen

Middelbare commercieel-agrarische beroepen

Elementaire beroepen

Lagere technisch-agrarische beroepen

\section{MBO techniek}

Middelbare bouwkundige beroepen $\quad 16$

Middelbare werktuigbouwkundige beroepen ed 15

Middelbare elektrotechnische beroepen (excl. automat. ed) 13

Lagere verkoopberoepen

Elementaire beroepen

\section{MBO economie}

Middelbare administatieve beroepen (excl. automat. ed) ed 
Tabel 22A (vervolg)

Belangrijkste beroepsgroepen waarin schoolverlaters werkzaam zijn per opleidingscluster

$\%$

$\mathrm{MBO}$ dienstverlening/verzorging

Middelbare alg. verzorgende beroepen

28

Middelbare alg. (para)medische beroepen

Lagere alg. verzorgende beroepen ed

Lagere verkoopberoepen

Lagere (para)medische beroepen

Middelbare technisch-(para)medische beroepen

geen gegevens vanwege kleine aantallen:

VBO overig

MBO-kort overig

MBO overig

\section{Toelichting}

De beroepen waarin de schoolverlaters werkzaam zijn, zijn geclassificeerd volgens de in 1992 grondig herziene Standaard Beroepenclassificatie van het CBS. Op het hier gepresenteerde niveau van beroepsgroepen worden in totaal 121 categorieën onderscheiden.

In de tabel zijn alleen die beroepsgroepen weergegeven, waarin ten minste $5 \%$ van de schoolverlaters werkzaam zijn.

Het gaat hier alleen om werkende schoolverlaters die niet doorstromen naar het voltijd dagonderwijs. 
Tabel 22B

Belangrijkste beroepsgroepen waarin schoolverlaters werkzaam zijn per opleidingsrichting

$\%$

MAVO

Lagere verkoopberoepen 22

Elementaire beroepen

Lagere alg. verzorgende beroepen ed

Lagere bouwkundige beroepen

HAVO

Elementaire beroepen

Lagere (para)medische beroepen

Lagere verkoopberoepen

Middelbare commerciele beroepen ed

Lagere administratieve beroepen

Lagere bouwkundige beroepen

Lagere technische beroepen neg

Lagere alg. verzorgende beroepen ed

VWO

Lagere verkoopberoepen

Middelbare administatieve beroepen (excl. automat. ed) ed

Lagere alg. verzorgende beroepen ed

Middelbare commerciele beroepen ed

Hogere administratieve beroepen (excl. automat. ed)

Lagere administratieve beroepen

Middelbare beveiligingsberoepen

VBO landbouw

Lagere agrarische beroepen

Lagere verkoopberoepen

Elementaire beroepen

Lagere alg. verzorgende beroepen ed

VBO bouwtechniek

Lagere bouwkundige beroepen

Middelbare bouwkundige beroepen

Elementaire beroepen

VBO mechanische techniek

Lagere metaalkundige beroepen

Elementaire beroepen

Lagere werktuigbouwkundige beroepen ed

Lagere procestechnische beroepen

Middelbare metaalkundige beroepen

VBO elektrotechniek

Elementaire beroepen

Lagere elektrotechnische beroepen

Lagere bouwkundige beroepen

Lagere werktuigbouwkundige beroepen ed 
Tabel 22B (vervolg)

Belangrijkste beroepsgroepen waarin schoolverlaters werkzaam zijn per opleidingsrichting

$\%$

VBO motorvoertuigentechniek

Lagere werktuigbouwkundige beroepen ed $\quad 50$

Lagere bouwkundige beroepen $\quad 13$

Elementaire beroepen 10

Lagere metaalkundige beroepen

$\begin{array}{ll}\text { Middelbare werktuigbouwkundige beroepen ed } & 7\end{array}$

VBO consumptieve techniek

Lagere alg. verzorgende beroepen ed 42

Middelbare procestechnische beroepen $\quad 29$

Elementaire beroepen $\quad 8$

Lagere verkoopberoepen $\quad 6$

Lagere bouwkundige beroepen $\quad 6$

VBO verzorging

Lagere verkoopberoepen $\quad 39$

Elementaire beroepen 17

Lagere alg. verzorgende beroepen ed 17

Lagere (para)medische beroepen $\quad 13$

MBO-kort landbouw

Lagere agrarische beroepen $\quad 31$

Lagere verkoopberoepen $\quad 34$

Elementaire beroepen $\quad 16$

Lagere technisch-agrarische beroepen $\quad 6$

MBO-kort elektrotechniek

Middelbare elektrotechnische beroepen (excl. automat. ed) 40

$\begin{array}{ll}\text { Lagere elektrotechnische beroepen } & 10\end{array}$

Middelbare werktuigbouwkundige beroepen ed 9

Elementaire beroepen $\quad 8$

Lagere metaalkundige beroepen $\quad 7$

Middelbare elektrotechnische beroepen (automat. ed)

Lagere werktuigbouwkundige beroepen ed $\quad 6$

Lagere verkoopberoepen

MBO-kort motorv. techniek

Middelbare werktuigbouwkundige beroepen ed 77

Lagere werktuigbouwkundige beroepen ed

MBO-kort consumptieve techniek

Lagere alg. verzorgende beroepen ed

Middelbare alg. verzorgende beroepen

Middelbare procestechnische beroepen

Lagere verkoopberoepen

MBO-kort overig techniek

Middelbare bouwkundige beroepen 
Tabel 22B (vervolg)

Belangrijkste beroepsgroepen waarin schoolverlaters werkzaam zijn per opleidingsrichting

$\%$

Lagere bouwkundige beroepen

10

Lagere technisch-agrarische beroepen

Middelbare werktuigbouwkundige beroepen ed

MBO-kort (detail)handel

Lagere verkoopberoepen

Elementaire beroepen

Lagere administratieve beroepen

MBO-kort administratie

Lagere administratieve beroepen

36

Middelbare administatieve beroepen (excl. automat. ed) ed

Lagere verkoopberoepen

Elementaire beroepen

MBO-kort verzorging

Elementaire beroepen

Lagere (para)medische beroepen

Middelbare alg. verzorgende beroepen

Lagere alg. verzorgende beroepen ed

Lagere verkoopberoepen

MBO plantenteelt

Lagere agrarische beroepen

Middelbare commercieel-agrarische beroepen

Lagere technisch-agrarische beroepen

$M B O$ veehouderij

Lagere agrarische beroepen

Lagere technisch-agrarische beroepen

Elementaire beroepen

Middelbare commercieel-agrarische beroepen

MBO levensmiddelentechnologie

Middelbare procestechnische beroepen

Middelbare wiskundige, natuurwet. beroepen

Lagere procestechnische beroepen

Elementaire beroepen

Lagere verkoopberoepen

11

Lagere alg. verzorgende beroepen ed

MBO bloemschikken

Lagere verkoopberoepen

Middelbare (technisch-)agrarische beroepen

$\mathrm{MBO}$ dierenverzorging

Middelbare alg. (para)medische beroepen 
Tabel 22B (vervolg)

Belangrijkste beroepsgroepen waarin schoolverlaters werkzaam zijn per opleidingsrichting

$\%$

Elementaire beroepen

Lagere procestechnische beroepen

$\mathrm{MBO}$ groene ruimte

Lagere agrarische beroepen

Middelbare commercieel-agrarische beroepen

Lagere verkoopberoepen

Middelbare (technisch-)agrarische beroepen

MBO bouwkunde

Middelbare bouwkundige beroepen

Lagere bouwkundige beroepen

MBO elektrotechniek

Middelbare elektrotechnische beroepen (excl. automat. ed)

Lagere verkoopberoepen

Middelbare werktuigbouwkundige beroepen ed

Middelbare elektrotechnische beroepen (automat. ed)

Elementaire beroepen

Middelbare bouwkundige beroepen

Lagere bouwkundige beroepen

\section{MBO werktuigbouwkunde}

Middelbare werktuigbouwkundige beroepen ed 22

Middelbare bouwkundige beroepen

Lagere metaalkundige beroepen

Middelbare elektrotechnische beroepen (excl. automat. ed)

Lagere procestechnische beroepen

$M B O$ weg- en waterbouwkunde

Middelbare weg- en waterbouwkundige beroepen

Lagere weg- en waterbouwkundige beroepen

Middelbare commerciele beroepen ed

Middelbare bouwkundige beroepen

MBO motorvoertuigentechniek

Middelbare werktuigbouwkundige beroepen ed

Elementaire beroepen

Middelbare metaalkundige beroepen

Middelbare elektrotechnische beroepen (excl. automat. ed)

MBO grafische techniek

Middelbare kunstzinnige beroepen

Lagere grafische beroepen

Middelbare grafische beroepen ed

Middelbare bedrijfskundige beroepen

Middelbare commerciele beroepen ed

.

.

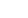


Tabel 22B (vervolg)

Belangrijkste beroepsgroepen waarin schoolverlaters werkzaam zijn per opleidingsrichting

MBO proces- en laboratoriumtechniek

Middelbare wiskundige, natuurwet. beroepen $\quad 28$

Middelbare procestechnische beroepen $\quad 28$

Elementaire beroepen $\quad 10$

Lagere procestechnische beroepen $\quad 8$

MBO mode \& kleding (tech)

Lagere verkoopberoepen 34

Lagere technische beroepen neg $\quad 13$

$\begin{array}{lr}\text { Middelbare verkoopberoepen } & 8\end{array}$

Middelbare technische beroepen neg $\quad 8$

Middelbare administatieve beroepen (excl. automat. ed) ed 5

MBO overig techniek

Middelbare werktuigbouwkundige beroepen ed $\quad 38$

$\begin{array}{ll}\text { Elementaire beroepen } & 12\end{array}$

Lagere technisch-agrarische beroepen 12

Middelbare elektrotechnische beroepen (automat. ed) 12

Middelbare elektrotechnische beroepen (excl. automat. ed) 10

$\begin{array}{ll}\text { Lagere verkoopberoepen } & 7\end{array}$

MBO administratie

Middelbare administatieve beroepen (excl. automat. ed) ed 51

Middelbare commerciele beroepen ed 9

Lagere administratieve beroepen $\quad 7$

Elementaire beroepen $\quad 5$

Lagere (technisch-)commerciele beroepen $\quad 5$

$M B O$ secretariaat

Middelbare administatieve beroepen (excl. automat. ed) ed 46

Lagere administratieve beroepen $\quad 24$

Middelbare commerciele beroepen ed 9

Middelbare juridische, bestuurlijke beroepen $\quad 6$

MBO commercieel

Middelbare administatieve beroepen (excl. automat. ed) ed $\quad 28$

$\begin{array}{ll}\text { Lagere verkoopberoepen } & 17\end{array}$

Middelbare commerciele beroepen ed 16

Lagere administratieve beroepen $\quad 15$

Middelbare bedrijfskundige beroepen

Elementaire beroepen $\quad 5$

MBO vrije afstudeerrichting

Middelbare commerciele beroepen ed

Middelbare administatieve beroepen (excl. automat. ed) ed 25

Lagere administratieve beroepen $\quad 20$

$\begin{array}{lr}\text { Lagere verkoopberoepen } & 10\end{array}$

Elementaire beroepen $\quad 5$ 
Tabel 22B (vervolg)

Belangrijkste beroepsgroepen waarin schoolverlaters werkzaam zijn per opleidingsrichting

MBO toerisme en recreatie

Middelbare commerciele beroepen ed

Lagere administratieve beroepen

Middelbare administatieve beroepen (excl. automat. ed) ed

Middelbare verzorgende transportberoepen

\section{MBO logistiek}

Middelbare bedrijfskundige beroepen

Middelbare administatieve beroepen (excl. automat. ed) ed

Middelbare economisch-administratieve transportberoepen

Elementaire beroepen

Lagere verkoopberoepen

Middelbare commerciele beroepen ed

Middelbare technisch-(para)medische beroepen

MBO (detail)handel

Lagere verkoopberoepen

Middelbare verkoopberoepen

Elementaire beroepen

Middelbare administatieve beroepen (excl. automat. ed) ed

Middelbare commerciele beroepen ed

Lagere administratieve beroepen

\section{MBO horeca}

Lagere alg. verzorgende beroepen ed

Lagere administratieve beroepen

Middelbare alg. verzorgende beroepen

Middelbare commercieel-verzorgende beroepen ed

Elementaire beroepen

Middelbare administatieve beroepen (excl. automat. ed) ed

Middelbare commerciele beroepen ed

\section{MBO overig economie}

Middelbare administatieve beroepen (excl. automat. ed) ed $\quad 40$

Lagere administratieve beroepen

Middelbare commerciele beroepen ed

Lagere verkoopberoepen

Elementaire beroepen

Middelbare juridische, bestuurlijke beroepen

$M B O$ agogisch werk

Middelbare alg. verzorgende beroepen

Elementaire beroepen 
Tabel 22B (vervolg)

Belangrijkste beroepsgroepen waarin schoolverlaters werkzaam zijn per opleidingsrichting

$\%$

Middelbare alg. (para)medische beroepen

Lagere alg. verzorgende beroepen ed

Middelbare verzorgend-(para)medische beroepen

Lagere verkoopberoepen

MBO assistenten gezondheidszorg

Middelbare alg. (para)medische beroepen

44

Middelbare technisch-(para)medische beroepen

$M B O$ mode en kleding (verz)

Lagere verkoopberoepen

Middelbare verkoopberoepen

Middelbare administatieve beroepen (excl. automat. ed) ed

$\mathrm{MBO}$ activiteitenbegeleiding

Hogere alg., verzorgende (para)medische beroepen

Middelbare sociaal-maatschappelijke beroepen ed 10

Middelbare alg. verzorgende beroepen

Lagere alg. verzorgende beroepen ed

Elementaire beroepen

MBO facilitaire dienstverlening

Lagere alg. verzorgende beroepen ed

Elementaire beroepen

20

Middelbare alg. verzorgende beroepen

Lagere technische beroepen neg

$\mathrm{MBO}$ uiterlijke verzorging

Middelbare alg. verzorgende beroepen

Lagere verkoopberoepen

Lagere alg. verzorgende beroepen ed

MBO sociale arbeid

Middelbare administatieve beroepen (excl. automat. ed) ed 22

Middelbare sociaal-maatschappelijke beroepen ed

Lagere administratieve beroepen

Lagere verkoopberoepen

Elementaire beroepen

Middelbare commerciele beroepen ed

Lagere beveiligingsberoepen

Middelbare verkoopberoepen

Middelbare alg. verzorgende beroepen

1
7
6
5


Tabel 22B (vervolg)

Belangrijkste beroepsgroepen waarin schoolverlaters werkzaam zijn per opleidingsrichting

geen gegevens vanwege kleine aantallen:

VBO installatietechniek

VBO grafische techniek

VBO overig techniek

VBO administratie

VBO verkoop

VBO handel

VBO uiterlijke verzorging

VBO mode en kleding

VB0 overig

MBO-kort werktuigbouw

MBO-kort overig dienstverlening/verzorging

MBO-kort overig

MBO overig landbouw

MB0 mechanische techniek

MBO nautisch

MBO economisch-juridisch

MB0 overig dienstverlening/verzorging

$\mathrm{MBO}$ overig

\section{Toelichting}

De beroepen waarin de schoolverlaters werkzaam ziin, ziin geclassificeerd volgens de in 1992 grondig herziene Standaard Beroepenclassificatie van het CBS. Op het hier gepresenteerde niveau van beroepsgroepen worden in totaal 121 categorieën onderscheiden.

In de tabel zijn alleen die beroepsgroepen weergegeven, waarin ten minste $5 \%$ van de schoolverlaters werkzaam zijn.

Het gaat hier alleen om werkende schoolverlaters die niet doorstromen naar het voltijd dagonderwijs. 
Tabel 23A

Grootte van de organisatie waarin schoolverlaters werkzaam zijn per opleidingscluster

\begin{tabular}{|c|c|c|c|c|c|c|c|c|c|}
\hline Opleidingscluster & 1 pers & $\begin{array}{l}2 \mathrm{t} / \mathrm{m} \\
9 \text { pers }\end{array}$ & $\begin{array}{c}10 \mathrm{t} / \mathrm{m} \\
19 \\
\text { pers } \\
\%\end{array}$ & $\begin{array}{c}20 \mathrm{t} / \mathrm{m} \\
49 \\
\text { pers } \\
\% \\
\%\end{array}$ & $\begin{array}{c}50 \mathrm{t} / \mathrm{m} \\
99 \\
\text { pers } \\
\%\end{array}$ & $\begin{array}{c}100 \\
t / m \\
499 \\
\text { pers } \\
\%\end{array}$ & $\begin{array}{c}500 \\
t / m \\
999 \\
\text { pers } \\
\%\end{array}$ & $\begin{array}{c}>= \\
1000 \\
\text { pers } \\
\%\end{array}$ & $\begin{array}{c}\text { Totaal } \\
N=100 \%\end{array}$ \\
\hline AVO & 1 & 27 & 14 & 8 & 11 & 8 & 5 & 26 & 288 \\
\hline MAVO & 0 & 35 & 14 & 6 & 14 & 10 & 6 & 14 & 138 \\
\hline HAVO & 0 & 19 & 15 & 7 & 13 & 7 & 5 & 34 & 93 \\
\hline WW0 & 3 & 21 & 13 & 16 & 0 & 3 & 34 & 40 & 57 \\
\hline VBO & 2 & 32 & 14 & 14 & 10 & 12 & 5 & 13 & 722 \\
\hline landbouw & 6 & 36 & 20 & 9 & 7 & 7 & 0 & 14 & 29 \\
\hline techniek & 1 & 32 & 14 & 14 & 11 & 13 & 5 & 10 & 495 \\
\hline economie & 1 & 25 & 12 & 9 & 9 & 12 & 5 & 26 & 82 \\
\hline dienstverlening/verzorging & 6 & 35 & 11 & 15 & 5 & 10 & 4 & 14 & 110 \\
\hline overig & - & - & - & - & - & - & - & - & - \\
\hline MBO-kort & 1 & 24 & 15 & 15 & 14 & 11 & 6 & 14 & 389 \\
\hline landbouw & 8 & 37 & 17 & 18 & 5 & 5 & 3 & 8 & 12 \\
\hline techniek & 1 & 29 & 17 & 13 & 14 & 12 & 4 & 9 & 156 \\
\hline economie & 0 & 20 & 14 & 15 & 12 & 12 & 6 & 20 & 164 \\
\hline dienstverlening/verzorging & 4 & 23 & 8 & 16 & 16 & 10 & 10 & 11 & 39 \\
\hline overig & - & - & - & - & - & - & - & - & - \\
\hline MBO-tussen en -lang & 2 & 21 & 12 & 17 & 11 & 14 & 7 & 17 & 1482 \\
\hline landbouw & 7 & 49 & 12 & 10 & 6 & 8 & 3 & 5 & 107 \\
\hline techniek & 1 & 19 & 11 & 21 & 13 & 13 & 5 & 17 & 421 \\
\hline economie & 1 & 19 & 14 & 18 & 10 & 12 & 5 & 20 & 517 \\
\hline dienstverlening/verzorging & 2 & 18 & 10 & 13 & 12 & 17 & 11 & 17 & 418 \\
\hline overig & - & - & - & - & - & - & - & $\cdots$ & - \\
\hline Totaal & 1 & 25 & 13 & 15 & 11 & 12 & 6 & 17 & 2881 \\
\hline
\end{tabular}

Toelichting

Vraag in de enquête: Hoeveel mensen werken er ongeveer bij de organisatie of het bedrij. Het gaat nu om alle werknemers van dit bedrijf in Nederland.

Het gaat hier alleen om werkende schoolverlaters die niet doorstromen naar het voltiid dagonderwijs. 
Tabel 23B

Grootte van de organisatie waarin schoolverlaters werkzaam zijn per opleidingsrichting

$\begin{array}{ccccccccccc}\text { Opleidingsrichting } & 1 \text { pers } & 2 \mathrm{t} / \mathrm{m} & 10 \mathrm{t} / \mathrm{m} & 20 \mathrm{t} / \mathrm{m} & 50 \mathrm{t} / \mathrm{m} & 100 & 500 & >= & \text { Totaal } \\ & & 9 \text { pers } & 19 & 49 & 99 & t / m & t / m & 1000 & \mathrm{~N}=100 \% \\ & & & \text { pers } & \text { pers } & \text { pers } & \begin{array}{c}499 \\ \text { pers }\end{array} & \begin{array}{c}999 \\ \text { pers }\end{array} & \text { pers } \\ & & \% & \% & \% & \% & \% & \% & \%\end{array}$

AVO

MAVO

HAVO

WWO

$\begin{array}{rrrrrrrrr}0 & 35 & 14 & 6 & 14 & 10 & 6 & 14 & 138 \\ 0 & 19 & 15 & 7 & 13 & 7 & 5 & 34 & 93 \\ 3 & 21 & 13 & 16 & 0 & 3 & 4 & 40 & 57\end{array}$

VBO

landbouw

bouwtechniek

$\begin{array}{rrrrrrrrr}6 & 36 & 20 & 9 & 7 & 7 & 0 & 14 & 29 \\ 0 & 31 & 18 & 13 & 7 & 18 & 7 & 6 & 137 \\ 0 & 32 & 3 & 16 & 16 & 10 & 13 & 10 & 90 \\ - & - & - & - & - & - & - & - & - \\ 0 & 37 & 13 & 13 & 10 & 17 & 0 & 10 & 91 \\ 0 & 32 & 29 & 13 & 14 & 5 & 1 & 6 & 75 \\ - & - & - & - & - & - & - & - & - \\ - & - & - & - & - & - & - & - & - \\ - & - & - & - & - & - & - & - & - \\ - & - & - & - & - & - & - & - & - \\ - & - & - & - & - & - & - & - & - \\ - & - & - & - & - & - & - & - & - \\ 9 & 27 & 7 & 14 & 7 & 14 & 6 & 15 & 73\end{array}$

chanische techr

motorvoertuigentechniek

consumptieve techniek

installatietechniek

grafische techniek

overig techniek

administratie

verkoop

handel

verzorging

uiterlijke verzorging

mode en kleding

overig

MBO-kort

landbouw

elektrotechniek

motorv. techniek

consumptieve techniek

werktuigbouw

overig techniek

(detail)handel

administratie

verzorging

overig dienstverlening/

verzorging

overig

MBO-tussen en -lang

veehouderij

levensmiddelentechnologie 0

bloemschikken

dierenverzorging

groene ruimte

overig landbouw

bouwkunde

elektrotechniek

werktuigbouwkund

weg-en waterbouwkunde

$\begin{array}{rrrrrrrrr}8 & 37 & 17 & 18 & 5 & 5 & 3 & 8 & 12 \\ 0 & 28 & 11 & 16 & 23 & 15 & 2 & 4 & 18 \\ 4 & 36 & 28 & 4 & 12 & 8 & 4 & 4 & 38 \\ 0 & 31 & 18 & 18 & 15 & 7 & 3 & 10 & 41 \\ - & - & - & - & - & - & - & - & - \\ 0 & 29 & 11 & 14 & 14 & 18 & 4 & 11 & 28 \\ 0 & 28 & 16 & 14 & 9 & 7 & 2 & 23 & 61 \\ 1 & 15 & 13 & 16 & 14 & 14 & 9 & 18 & 103 \\ 6 & 12 & 9 & 13 & 25 & 12 & 12 & 13 & 26\end{array}$


Tabel 23B (vervolg)

Grootte van de organisatie waarin schoolverlaters werkzaam zijn per opleidingsrichting

\begin{tabular}{|c|c|c|c|c|c|c|c|c|c|}
\hline Opleidingsrichting & 1 pers & $\begin{array}{l}2 \mathrm{t} / \mathrm{m} \\
9 \text { pers }\end{array}$ & $\begin{array}{c}10 \mathrm{t} / \mathrm{m} \\
19 \\
\text { pers } \\
\% \\
\%\end{array}$ & $\begin{array}{c}20 \mathrm{t} / \mathrm{m} \\
49 \\
\text { pers } \\
\% \\
\end{array}$ & $\begin{array}{c}50 \mathrm{t} / \mathrm{m} \\
99 \\
\text { pers } \\
\\
\%\end{array}$ & $\begin{array}{c}100 \\
t / m \\
499 \\
\text { pers } \\
\%\end{array}$ & $\begin{array}{c}500 \\
t / m \\
999 \\
\text { pers } \\
\%\end{array}$ & $\begin{array}{c}>= \\
1000 \\
\text { pers } \\
\%\end{array}$ & $\begin{array}{c}\text { Totaal } \\
N=100 \%\end{array}$ \\
\hline motorvoertuigentechniek & 0 & 39 & 3 & 19 & 10 & 27 & 1 & 1 & 25 \\
\hline mechanische techniek & - & - & - & - & - & - & - & - & - \\
\hline $\begin{array}{l}\text { grafische techniek } \\
\text { proces- en }\end{array}$ & 1 & 27 & 15 & 23 & 12 & 12 & 3 & 7 & 15 \\
\hline laboratoriumtechniek & 0 & 7 & 11 & 12 & 16 & 9 & 13 & 32 & 36 \\
\hline nautisch & - & - & - & - & - & - & - & - & - \\
\hline mode \& kleding (techn) & 1 & 13 & 14 & 22 & 11 & 6 & 9 & 24 & 33 \\
\hline overig techniek & 3 & 33 & 13 & 23 & 10 & 5 & 8 & 8 & 40 \\
\hline administratie & 0 & 16 & 8 & 18 & 13 & 16 & 3 & 26 & 65 \\
\hline secretariaat & 0 & 14 & 18 & 20 & 8 & 12 & 7 & 22 & 86 \\
\hline commercieel & 0 & 14 & 8 & 28 & 10 & 14 & 5 & 22 & 44 \\
\hline economisch-juridisch & - & - & - & - & - & - & - & - & - \\
\hline vrije afstudeerrichting & 0 & 16 & 23 & 7 & 9 & 14 & 2 & 29 & 21 \\
\hline toerisme en recreatie & 0 & 19 & 11 & 19 & 11 & 15 & 6 & 18 & 37 \\
\hline logistiek & 0 & 9 & 19 & 15 & 24 & 12 & 15 & 6 & 3 \\
\hline (detail)handel & 2 & 25 & 16 & 16 & 8 & 10 & 6 & 18 & 144 \\
\hline horeca & 0 & 20 & 11 & 19 & 17 & 11 & 2 & 20 & 37 \\
\hline overig economie & 0 & 19 & 13 & 19 & 12 & 13 & 7 & 17 & 69 \\
\hline agogisch werk & 1 & 15 & 11 & 15 & 12 & 16 & 14 & 15 & 93 \\
\hline verzorging & 1 & 4 & 4 & 15 & 20 & 28 & 11 & 17 & 110 \\
\hline assistenten gezondheidszorg & $\operatorname{rg} 5$ & 40 & 21 & 8 & 1 & 5 & 6 & 14 & 75 \\
\hline mode \& kleding (verz) & 1 & 31 & 9 & 15 & 3 & 11 & 14 & 15 & 35 \\
\hline activiteitenbegeleiding & 0 & 2 & 4 & 15 & 16 & 30 & 14 & 19 & 27 \\
\hline facilitaire dienstverlening & 0 & 9 & 12 & 16 & 21 & 7 & 2 & 33 & 20 \\
\hline uiterlijke verzorging & 7 & 52 & 9 & 13 & 3 & 7 & 1 & 9 & 22 \\
\hline sociale arbeid & 2 & 18 & 9 & 11 & 15 & 16 & 12 & 17 & 13 \\
\hline $\begin{array}{l}\text { verpleging } \\
\text { overig dienstverlening/ }\end{array}$ & 0 & 5 & 1 & 3 & 13 & 21 & 24 & 33 & 20 \\
\hline verzorging & - & - & - & - & - & - & - & - & - \\
\hline overig & - & - & - & - & - & - & - & - & - \\
\hline Totaal & 1 & 25 & 13 & 15 & 11 & 12 & 6 & 17 & 2881 \\
\hline
\end{tabular}

- = geen gegevens vanwege kleine aantallen

\section{Toelichting}

Vraag in de enquête: Hoeveel mensen werken er ongeveer bij de organisatie of het bedrijf. Het gaat nu om alle werknemers van dit bedrijf in Nederland.

Het gaat hier alleen om werkende schoolverlaters die niet doorstromen naar het voltijd dagonderwijs. 
Tabel 24A

Bedrijfsgroepenspreiding van de werkende schoolverlaters per opleidingscluster

Opleidingcluster

\begin{tabular}{lll}
\hline AVO & 0,93 & hoog \\
MAVO & 0,94 & hoog \\
HAVO & 0,92 & hoog \\
WWO & 0,93 & hoog \\
VBO & & \\
landbouw & 0,80 & gemiddeld \\
techniek & 0,90 & hoog \\
economie & 0,77 & gemiddeld \\
dienstverlening/verzorging & - & - \\
overig & 0,89 & hoog \\
& - & - \\
MBO-kort & & \\
landbouw & 0,84 & gemiddeld \\
techniek & 0,86 & gemiddeld \\
economie & 0,73 & laag \\
dienstverlening/verzorging & 0,93 & hoog \\
overig & 0,79 & gemiddeld \\
MBO-tussen en -lang & - & - \\
landbouw & & laag \\
techniek & 0,74 & erg laag \\
economie & 0,55 & gemiddeld \\
dienstverlening/verzorging & 0,81 & gemiddeld \\
overig & 0,88 & erg laag \\
\hline
\end{tabular}

- = geen gegevens vanwege kleine aantallen

spreidingsindex

typering

\section{Toelichting}

De bedrijfsgroepenspreiding wordt bepaald aan de hand van de Gini-Hirschman coëfficiënt. Deze index is gelijk aan 0 indien alle schoolverlaters in één bedrijfsgroep werkzaam zijn en gelijk aan 1 indien de schoolverlaters precies gelijk verdeeld over alle bedrijfsgroepen werkzaam zijn. Daarmee geeft deze indicator een beeld van de uitwijkmogelijkheden van schoolverlaters naar andere bedrijfsgroepen.

Overigens moet worden bedacht dat door de noodzakelijke classificatie van bedrijven en opleidingen de bedrijfsgroepenspreiding soms wordt overschat. Dit is bijvoorbeeld het geval bij de opleidingsrichting MBO assistenten gezondheidszorg, waarin de opleidingen apothekersassistent, doktersassistent en tandartsassistent zijn ondergebracht. Deze afzonderlijke opleidingen richten zich echter elk op een sterk afgebakend terrein van de arbeidsmarkt.

In deze tabel is het gewogen gemiddelde van de bedrijfsgroepenspreiding van de onderliggende opleidingsrichtingen gepresenteerd.

Het gaat hier alleen om werkende schoolverlaters die niet doorstromen naar het voltijd dagonderwijs. 
Tabel 24B

Bedrijfsgroepenspreiding van de werkende schoolverlaters per opleidingsrichting

Opleidingsrichting

spreidingsindex

typering

AVO

MAVO

HAVO

0,94

0,92

0,93

hoog

WWO

hoog

VBO

landbouw

bouwtechniek

elektrotechniek

motorvoertuigentechniek

consumptieve techniek

installatietechniek

grafische techniek

overig techniek

administratie

verkoop

handel

verzorging

uiterlijke verzorging

mode en kleding

overig

MBO-kort

landbouw

motorv. techniek

consumptieve techniek

(detail)handel

verzorging

overig dienstverlening/verzorging

overig

MBO-tussen en -lang

plantenteelt

veehouderij

levensmiddelentechnologie

bloemschikken

dierenverzorging

groene ruimte

overig landbouw

bouwkunde

elektrotechniek

werktuigbouwkunde

weg- en waterbouwkunde

motorvoertuigentechniek

mechanische techniek

grafische techniek 
Tabel 24B (vervolg)

Bedrijfsgroepenspreiding van de werkende schoolverlaters per opleidingsrichting

\begin{tabular}{lcl} 
Opleidingsrichting & spreidingsindex & typering \\
\hline mode en kleding & 0,78 & gemiddeld \\
overig techniek & 0,85 & gemiddeld \\
administratie & 0,96 & hoog \\
secretariaat & 0,93 & hoog \\
commercieel & 0,93 & hoog \\
economisch-juridisch & - & - \\
vrije afstudeerrichting & 0,86 & gemiddeld \\
toerisme en recreatie & 0,68 & laag \\
logistiek & - & - \\
(detail)handel & 0,88 & gemiddeld \\
horeca & 0,70 & laag \\
overig economie & 0,95 & hoog \\
agogisch werk & 0,59 & erg laag \\
verzorging & 0,59 & erg laag \\
assistenten gezondheidszorg & 0,52 & erg laag \\
mode en kleding & 0,47 & erg laag \\
activiteitenbegeleiding & 0,48 & erg laag \\
facilitaire dienstverlening & 0,89 & hoog \\
uiterlijke verzorging & 0,42 & erg laag \\
sociale arbeid & 0,88 & gemiddeld \\
verpleging & 0,49 & erg laag \\
overig dienstverlening/verzorging & - & - \\
overig & - & -
\end{tabular}

- = geen gegevens vanwege kleine aantallen

\section{Toelichting}

De bedrijfsgroepenspreiding wordt bepaald aan de hand van de Gini-Hirschman coëfficiënt. Deze index is gelijk aan 0 indien alle schoolverlaters in één bedrijfsgroep werkzaam zijn en gelijk aan 1 indien de schoolverlaters precies gelijk verdeeld over alle bedrijfsgroepen werkzaam zijn. Daarmee geeft deze indicator een beeld van de uitwijkmogelijkheden van schoolverlaters naar andere bedrijfsgroepen.

Overigens moet worden bedacht dat door de noodzakelijke classificatie van bedrijven en opleidingen de bedrijfsgroepenspreiding soms wordt overschat. Dit is bijvoorbeeld het geval bij de opleidingsrichting MBO assistenten gezondheidszorg, waarin de opleidingen apothekersassistent, doktersassistent en tandartsassistent zijn ondergebracht. Deze afzonderlijke opleidingen richten zich echter elk op een sterk afgebakend terrein van de arbeidsmarkt.

Het gaat hier alleen om werkende schoolverlaters die niet doorstromen naar het voltijd dagonderwijs. 
Tabel 25A

Beroepsgroepenspreiding van de werkende schoolverlaters per opleidingscluster

Opleidingscluster

\begin{tabular}{lcl}
\hline AVO & 0,89 & erg hoog \\
MAVO & 0,89 & - \\
HAVO & - & - \\
WWO & - & gemiddeld \\
VBO & 0,63 & hoog \\
landbouw & 0,79 & gemiddeld \\
techniek & 0,60 & - \\
economie & - & hoog \\
dienstverlening/verzorging & 0,77 & - \\
overig & - & gemiddeld \\
& & - \\
MBO-kort & 0,63 & laag \\
landbouw & - & gemiddeld \\
techniek & 0,53 & - \\
economie & 0,72 & - \\
dienstverlening/verzorging & - & gemiddeld \\
overig & - & erg laag \\
& & gemiddeld \\
MBO-tussen en -lang & 0,63 & gemiddeld \\
landbouw & 0,46 & laag \\
techniek & 0,63 & - \\
economie & 0,70 & \\
dienstverlening/verzorging & 0,55 & - \\
overig & & \\
\hline
\end{tabular}

- = geen gegevens vanwege kleine aantallen spreidingsindex

typering

erg hoog

erg hoog

emiddeld

hoog

gemiddeld

hoog

gemiddeld

laag

gemiddeld

gemiddeld

gemiddeld

\section{Toelichting}

De beroepsgroepenspreiding wordt bepaald aan de hand van de Gini-Hirschman coëfficiënt. Deze index is gelijk aan 0 indien alle schoolverlaters in één beroepsgroep werkzaam zijn en gelijk aan 1 indien de schoolverlaters precies gelijk verdeeld over alle beroepsgroepen werkzaam zijn. Daarmee geeft deze indicator een beeld van de uitwijkmogelijkheden van schoolverlaters naar andere beroepsgroepen.

Overigens moet worden bedacht dat door de noodzakelijke classificatie van beroep en opleidingen de beroepsgroepenspreiding soms wordt overschat. Dit is bijvoorbeeld het geval bij de opleidingsrichting MBO assistenten gezondheidszorg, waarin de opleidingen apothekersassistent, doktersassistent en tandartsassistent zijn ondergebracht. Deze afzonderlijke opleidingen richten zich echter elk op een sterk afgebakend terrein van de arbeidsmarkt.

In deze tabel is het gewogen gemiddelde van de bedrijfsgroepenspreiding van de onderliggende opleidingsrichtingen gepresenteerd.

Het gaat hier alleen om werkende schoolverlaters die niet doorstromen naar het voltijd dagonderwijs. 
Tabel 25B

Beroepsgroepenspreiding van de werkende schoolverlaters per opleidingsrichting

Opleidingsrichting

spreidingsindex

typering

AVO

MAVO

erg hoog

HAVO

VWO

VBO

landbouw

0,79

0,33

0,82

mechanische techniek

0,68

motorvoertuigentechniek

0,70

consumptieve techniek

installatietechniek

grafische techniek

overig techniek

administratie

verkoop

handel

verzorging

uiterlijke verzorging

mode en kleding

overig

MBO-kort

landbouw

elektrotechniek

motorv techniek

gemiddeld

consumptieve techniek

werktuigbouw

overig techniek

(detail)handel

administratie

hoog

erg laag

hoog

gemiddeld

gemiddeld

verzorging

overig dienstverlening/verzorging

overig

MBO-tussen en -lang

plantenteelt

veehouderij

ensmiddelentechnologie

dierenverzorging

groene ruimte

overig landbouw

bouwkunde

elektrotechniek

werktuigbouwkunde

weg- en waterbouwkunde

motorvoertuigentechniek

grafische techniek

gemiddeld

erg laag

hoog

erg hoog

erg laag

gemiddeld

gemiddeld nautisch 
Tabel 25B (vervolg)

Beroepsgroepenspreiding van de werkende schoolverlaters per opleidingsrichting

Opleidingsrichting

spreidingsindex

mode en kleding

overig techniek

administratie

secretariaat

commercieel

economisch-juridisch

vrije afstudeerrichting

toerisme en recreatie

logistiek

(detail)handel

horeca

overig economie

agogisch werk

verzorging

assistenten gezondheidszorg

mode en kleding

activiteitenbegeleiding

facilitaire dienstverlening

uiterlijke verzorging

sociale arbeid

verpleging

overig dienstverlening/verzorging

overig

$\begin{aligned} 0,76 & \text { hoog } \\ 0,68 & \text { gemiddeld } \\ 0,57 & \text { laag } \\ 0,65 & \text { gemiddeld } \\ 0,77 & \text { hoog } \\ - & - \\ 0,77 & \text { hoog } \\ 0,62 & \text { gemiddeld } \\ - & - \\ 0,78 & \text { hoog } \\ 0,86 & \text { erg hoog } \\ 0,67 & \text { gemiddeld } \\ 0,49 & \text { erg laag } \\ 0,61 & \text { gemiddeld } \\ 0,59 & \text { laag } \\ 0,42 & \text { erg laag } \\ 0,38 & \text { erg laag } \\ - & - \\ 0,24 & \text { erg laag } \\ 0,79 & \text { hoog } \\ 0,79 & \text { hoog } \\ - & - \\ - & - \\ & -\end{aligned}$

- = geen gegevens vanwege kleine aantallen typering

hoog

laag

gemiddeld

hoog

emiddeld

hoog

erg laag

gemiddeld

laag

erg laag

erg laag

hoog

\section{Toelichting}

De beroepsgroepenspreiding wordt bepaald aan de hand van de Gini-Hirschman coëfficiënt. Deze index is gelijk aan 0 indien alle schoolverlaters in één beroepsgroep werkzaam zijn en gelijk aan 1 indien de schoolverlaters precies gelijk verdeeid over alle beroepsgroepen werkzaam zijn. Daarmee geeft deze indicator een beeld van de uitwijkmogelijkheden van schoolverlaters naar andere beroepsgroepen.

Overigens moet worden bedacht dat door de noodzakelijke classificatie van beroep en opleidingen de beroepsgroepenspreiding soms wordt overschat. Dit is bijvoorbeeld het geval bij de opleidingsrichting $\mathrm{MBO}$ assistenten gezondheidszorg, waarin de opleidingen apothekersassistent, doktersassistent en tandartsassistent zijn ondergebracht. Deze afzonderlijke opleidingen richten zich echter elk op een sterk afgebakend terrein van de arbeidsmarkt.

Het gaat hier alleen om werkende schoolverlaters die niet doorstromen naar het voltijd dagonderwijs. 
Tabel 26A

Conjunctuurgevoeligheid van de werkgelegenheid in de bedrijfsklassen waar schoolverlaters werkzaam zijn per opleidingscluster

Opleidingscluster

conjunctuurindicator

\begin{tabular}{lll}
\hline AVO & 0,64 & gemiddeld \\
MAVO & 0,67 & gemiddeld \\
HAVO & 0,64 & gemiddeld \\
Vemiddeld \\
WWO & 0,56 & \\
VBO & & erg hoog \\
landbouw & 0,87 & laag \\
techniek & 0,49 & erg hoog \\
economie & 1,04 & gemiddeld \\
dienstverlening/verzorging & 0,54 & laag \\
overig & 0,49 & - \\
MBO-kort & - & \\
landbouw & & gemiddeld \\
techniek & 0,66 & laag \\
economie & 0,41 & hoog \\
dienstverlening/verzorging & 0,81 & gemiddeld \\
overig & 0,58 & gemiddeld \\
MBO-tussen en -lang & 0,52 & - \\
landbouw & - & gemiddeld \\
techniek & & laag \\
economie & 0,65 & erg hoog \\
dienstverlening/verzorging & 0,49 & gemiddeld \\
overig & 0,95 & laag
\end{tabular}

- = geen gegevens vanwege kleine aantallen

\section{Toelichting}

De conjunctuurgevoeligheid van de werkgelegenheid geeft aan in welke mate de werkgelegenheid voor schoolverlaters met een bepaalde opleiding gevoelig is voor veranderingen in de economische situatie. De conjunctuurgevoeligheid wordt bepaald door de sectorale werkgelegenheidsfluctuaties in het verleden te relateren aan de mate waarin een opleiding in de verschillende bedrijfssectoren is vertegenwoordigd.

(zie ROA (1995), Methodiek van het Informatiesysteem Onderwiis-Arbeidsmarkt 1995, ROA-W1995/3, Maastricht). 
Tabel 26B

Conjunctuurgevoeligheid van de werkgelegenheid in de bedrijfsklassen waar schoolverlaters werkzaam zijn per opleidingsrichting

\section{Opleidingsrichting}

conjunctuurindicator

typering

AVO

MAVO

HAVO

0,67

0,64

VWO

0,56

gemiddeld

gemiddeld

gemiddeld

VBO

landbouw

bouwtechniek

mechanische techniek

elektrotechniek

motorvoertuigentechniek

consumptieve techniek

0,49

1,44

1,08

0,69

0,54

installatietechniek

grafische techniek

overig techniek

administratie

verkoop

handel

verzorging

uiterlijke verzorging

mode en kleding

overig

MBO-kort

landbouw

elektrotechniek

0,41

1,29

0,56

consumptieve

0,52

werktuigbouw

overig techniek

1,11

(detail)handel

0,53

administratie

0,59

verzorging

overig dienstverlening/verzorging

overig

MBO-tussen en -lang

plantenteelt

veehouderij

bloemschikken

dierenverzorging

0,42

groene ruimte

overig landbouw

bouwkunde

elektrotechniek

werktuigbouwkunde

weg- en waterbouwkunde

motorvoertuigentechniek

mechanische techniek

1,05

1,10

0,78

grafische techniek

0,74

laag

erg hoog

erg hoog

gemiddeld

gemiddeld

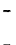

-

-

laag

-

laag

erg hoog gemiddeld laag

erg hoog gemiddeld gemiddeld laag

erg laag

laag

gemiddeld

laag

laag

gemiddeld

erg hoog

erg hoog

erg hoog

erg hoog

hoog

hoog 
Tabel 26B (vervolg)

Conjunctuurgevoeligheid van de werkgelegenheid in de bedrijfsklassen waar schoolverlaters werkzaam zijn per opleidingsrichting

\section{Opleidingsrichting}

conjunctuur-

typering

indicator

proces- en laboratoriumtechniek

0,82

hoog

nautisch

mode en kleding

0,82

overig techniek

0,61

gemiddeld

administratie

0,64

gemiddeld

secretariaat

0,65

gemiddeld

commercieel

0,70

gemiddeld

economisch-juridisch

vije afstudeerrichting

0,59

gemiddeld

toerisme en recreatie

gemiddeld

$\begin{array}{ll}0,58 & \text { gemiddeld } \\ 0,62 & \text { gemiddeld }\end{array}$

logistiek

0,60

gemiddeld

(detail)handel

0,54

horeca

gemiddeld

overig economie

0,48

0,65

0,45

agogisch werk

0,42

verzorging

assistenten gezondheidszorg

0,46

0,49

0,47

activiteitenbegeleiding

0,53

facilitaire diensstverlening

0,43

0,58

sociale arbeid

0,58

laag

gemiddeld

laag

laag

laag

laag

laag

gemiddeld

laag

verpleging

gemiddeld

overig dienstverlening/verzorging

overig

- = geen gegevens vanwege kleine aantallen

\section{Toelichting}

De conjunctuurgevoeligheid van de werkgelegenheid geeft aan in welke mate de werkgelegenheid voor schoolverlaters met een bepaalde opleiding gevoelig is voor veranderingen in de economische situatie. De conjunctuurgevoeligheid wordt bepaald door de sectorale werkgelegenheidsfluctuaties in het verleden te relateren aan de mate waarin een opleiding in de verschillende bedrijfssectoren is vertegenwoordigd.

(zie ROA (1995), Methodiek van het Informatiesysteem Onderwijs-Arbeidsmarkt 1995, ROA-W1995/3, Maastricht). 
Tabel 27A

Oordeel van de werkende schoolverlaters over de aansluiting van de afgesloten opleiding met de huidige baan per opleidingscluster

\begin{tabular}{|c|c|c|c|c|c|}
\hline Opleidingscluster & $\begin{array}{c}\text { goed } \\
\%\end{array}$ & $\begin{array}{c}\text { voldoende } \\
\%\end{array}$ & $\begin{array}{c}\text { matig } \\
\%\end{array}$ & $\begin{array}{c}\text { slecht } \\
\%\end{array}$ & $\begin{array}{c}\text { Totaal } \\
\mathrm{N}=100 \%\end{array}$ \\
\hline AVO & 41 & 27 & 13 & 18 & 316 \\
\hline MAVO & 43 & 23 & 12 & 22 & 143 \\
\hline HAVO & 36 & 32 & 14 & 18 & 112 \\
\hline VW0 & 48 & 26 & 15 & 11 & 61 \\
\hline VBO & 50 & 31 & 12 & 8 & 792 \\
\hline landbouw & 44 & 31 & 10 & 15 & 34 \\
\hline techniek & 50 & 29 & 12 & 8 & 540 \\
\hline economie & 59 & 26 & 10 & 4 & 97 \\
\hline dienstverlening/verzorging & 42 & 40 & 11 & 7 & 115 \\
\hline overig & - & - & - & - & - \\
\hline MBO-kort & 32 & 37 & 16 & 14 & 421 \\
\hline landbouw & 33 & 23 & 21 & 23 & 12 \\
\hline techniek & 36 & 32 & 17 & 16 & 166 \\
\hline economie & 29 & 46 & 14 & 11 & 182 \\
\hline dienstverlening/verzorging & 39 & 30 & 17 & 13 & 42 \\
\hline overig & - & - & - & - & - \\
\hline MBO-tussen en -lang & 32 & 38 & 19 & 11 & 1560 \\
\hline landbouw & 36 & 39 & 14 & 10 & 111 \\
\hline techniek & 26 & 37 & 24 & 13 & 428 \\
\hline economie & 32 & 39 & 19 & 10 & 533 \\
\hline dienstverlening/verzorging & 36 & 37 & 17 & 11 & 470 \\
\hline overig & - & - & - & - & - \\
\hline Totaal & 37 & 35 & 16 & 12 & 3090 \\
\hline
\end{tabular}

Toelichting

Vraag in de enquête: Hoe vind je de aansluiting tussen je opleiding van vorig jaar en je huidige bezigheden?

Het gaat hier alleen om werkende schoolverlaters die niet doorstromen naar het voltijd dagonderwijs. 
Tabel 27B

Oordeel van de werkende schoolverlaters over de aansluiting van de afgesloten opleiding met de huidige baan per opleidingsrichting

Opleidingsrichting

$$
\text { goed }
$$

$\%$

AVO

MAVO

HAVO

VWO

VBO

landbouw

bouwtechniek

mechanische techniek

elektrotechniek

motorvoertuigentechniek

consumptieve techniek

installatietechniek

grafische techniek

overig techniek

administratie

verkoop

handel

verzorging

uiterlijke verzorging

mode en kleding

overig

MBO-kort

landbouw

elektrotechniek

motorv. techniek

consumptieve techniek

werktuigbouw

overig techniek

(detail)handel

administratie

verzorging

overig dienstverlening/verzorging

overig

MBO-tussen en -lang

plantenteelt

veehouderij

levensmiddelentechnologie

bloemschikken

dierenverzorging

groene ruimte

overig landbouw

bouwkunde

elektrotechniek

werktuigbouwkunde

weg- en waterbouwkunde

motorvoertuigentechniek

mechanische techniek
43

36

48

voldoende

matig

slecht

Totaal

$\%$

$\%$

$\%$

$\begin{array}{rrr}12 & 22 & 143 \\ 14 & 18 & 112 \\ 15 & 11 & 61\end{array}$


Tabel 27B (vervolg)

Oordeel van de werkende schoolverlaters over de aansluiting van de afgesloten opleiding met de huidige baan per opleidingsrichting

\begin{tabular}{|c|c|c|c|c|c|}
\hline Opleidingsrichting & $\begin{array}{c}\text { goed } \\
\%\end{array}$ & $\begin{array}{c}\text { voldoende } \\
\%\end{array}$ & $\begin{array}{c}\text { matig } \\
\%\end{array}$ & $\begin{array}{c}\text { slecht } \\
\%\end{array}$ & $\begin{array}{c}\text { Totaal } \\
\mathrm{N}=100 \%\end{array}$ \\
\hline grafische techniek & 21 & 44 & 25 & 10 & 15 \\
\hline proces- en laboratoriumtechniek & 23 & 45 & 21 & 10 & 39 \\
\hline nautisch & - & - & - & - & - \\
\hline mode \& kleding (techn) & 21 & 39 & 20 & 20 & 35 \\
\hline overig techniek & 38 & 29 & 19 & 14 & 42 \\
\hline administratie & 20 & 49 & 19 & 13 & 66 \\
\hline secretariaat & 42 & 37 & 16 & 5 & 87 \\
\hline commercieel & 22 & 45 & 22 & 11 & 45 \\
\hline economisch-juridisch & - & - & - & - & - \\
\hline vrije afstudeerrichting & 11 & 52 & 21 & 16 & 22 \\
\hline toerisme en recreatie & 29 & 42 & 20 & 9 & 38 \\
\hline logistiek & 15 & 40 & 12 & 34 & 3 \\
\hline (detail)handel & 37 & 33 & 20 & 11 & 152 \\
\hline horeca & 39 & 41 & 16 & 3 & 37 \\
\hline overig economie & 31 & 35 & 21 & 14 & 72 \\
\hline agogisch werk & 29 & 37 & 21 & 12 & 107 \\
\hline verzorging & 45 & 37 & 12 & 6 & 129 \\
\hline assistenten gezondheidszorg & 43 & 40 & 11 & 7 & 80 \\
\hline mode \& kleding (verz) & 19 & 40 & 27 & 14 & 37 \\
\hline activiteitenbegeleiding & 29 & 41 & 14 & 16 & 27 \\
\hline facilitaire dienstverlening & 22 & 27 & 21 & 30 & 21 \\
\hline uiterlijke verzorging & 47 & 27 & 11 & 14 & 24 \\
\hline sociale arbeid & 24 & 33 & 16 & 27 & 14 \\
\hline verpleging & 35 & 42 & 17 & 6 & 23 \\
\hline overig dienstverlening/verzorging & - & - & - & - & - \\
\hline overig & - & - & - & - & - \\
\hline Totaal & 37 & 35 & 16 & 12 & 3090 \\
\hline
\end{tabular}

\section{Toelichting}

Vraag in de enquête: Hoe vind je de aansluiting tussen je opleiding van vorig jaar en je huidige bezigheden?

Het gaat hier alleen om werkende schoolverlaters die niet doorstromen naar het voltijd dagonderwijs. 
Kerngegevens / Schoolverlaters tussen onderwijs en arbeidsmarkt 1995 
Tabel 28

Percentage werkende schoolverlaters dat van mening is dat aan de onderscheiden aspecten van de afgesloten opleiding meer aandacht zou moeten worden besteed per opleidingscluster

\begin{tabular}{|c|c|c|c|c|c|c|}
\hline & MAVO & HAVO & vwo & $\begin{array}{l}\text { VBO } \\
\text { land- } \\
\text { bouw }\end{array}$ & $\begin{array}{c}\text { VBO } \\
\text { tech- } \\
\text { niek }\end{array}$ & $\begin{array}{c}\text { VBO } \\
\text { eco- } \\
\text { nomie }\end{array}$ \\
\hline & $\%$ & $\%$ & $\%$ & $\%$ & $\%$ & $\%$ \\
\hline Leren studeren & 18 & 24 & 16 & 27 & 25 & 22 \\
\hline Vreemde talen & 20 & 10 & 42 & 34 & 26 & 35 \\
\hline Met ciffers werken & 25 & 21 & 13 & 33 & 23 & 39 \\
\hline Informatica, automatisering & 57 & 86 & 81 & 44 & 40 & 40 \\
\hline Zelfstandig werken & 44 & 45 & 18 & 39 & 46 & 41 \\
\hline Organiserenplannen & 42 & 57 & 46 & 57 & 45 & 44 \\
\hline Correcte spelling/foutloos schrijven & 26 & 33 & 44 & 25 & 16 & 24 \\
\hline Een verslag of rapport schrijven & 37 & 54 & 59 & 27 & 20 & 28 \\
\hline Spreekvaardigheid & 29 & 38 & 69 & 30 & 13 & 41 \\
\hline Met klanten/patiënten omgaan & 43 & 47 & 38 & 51 & 29 & 35 \\
\hline Beroepskeuze/studiekeuze & 51 & 65 & 52 & 55 & 41 & 28 \\
\hline Leren solliciteren & 51 & 72 & 53 & 54 & 42 & 43 \\
\hline Vakkennis en vaktheorie & 30 & 46 & 26 & 38 & 36 & 28 \\
\hline Praktijkorientage of stage & 60 & 63 & 49 & 45 & 61 & 30 \\
\hline Omgaan met apparatuur of materialen & 55 & 48 & 58 & 54 & 50 & 49 \\
\hline Kennis van organisatie bedrijf & 47 & 47 & 37 & 57 & 51 & 35 \\
\hline Kennis van arbeidsvoorwaarden & 64 & 80 & 62 & 82 & 70 & 62 \\
\hline Commerciele kennis en verkooptechniek & 40 & 26 & 39 & 47 & 19 & 34 \\
\hline Samenwerken met collegas/medestudenten & 31 & 47 & 29 & 22 & 33 & 25 \\
\hline Onderscheiden van hoofd- en bijzaken & 31 & 31 & 46 & 30 & 25 & 24 \\
\hline
\end{tabular}

- = geen gegevens vanwege kleine aantallen

\section{Toelichting}

Vraag in de enquête: Hieronder noemen we een aantal onderwerpen. Moet daaraan in de opleiding die je vorig jaar hebt verlaten méér, evenveel of minder aandacht worden besteed?

Gepresenteerd is het percentage schoolverlaters dat vindt dat aan een aspect meer aandacht zou moeten worden besteed.

Het gaat hier alleen om werkende schoolverlaters die niet doorstromen naar het voltijd dagonderwijs. 


\begin{tabular}{|c|c|c|c|c|c|c|c|c|c|c|c|c|}
\hline $\begin{array}{l}\text { VBO } \\
\text { dienst } \\
\text { verl./ } \\
\text { verz }\end{array}$ & $\begin{array}{l}\text { VBO } \\
\text { overig }\end{array}$ & $\begin{array}{l}\text { MBO- } \\
\text { kort } \\
\text { land- } \\
\text { bouw }\end{array}$ & $\begin{array}{l}\text { MBO- } \\
\text { kort } \\
\text { tech- } \\
\text { niek }\end{array}$ & $\begin{array}{c}\text { MBO- } \\
\text { kort } \\
\text { eco- } \\
\text { nomie }\end{array}$ & $\begin{array}{c}\text { MBO- } \\
\text { kort } \\
\text { dienst } \\
\text { verl./verz }\end{array}$ & $\begin{array}{l}\text { MBO- } \\
\text { kort } \\
\text { overig }\end{array}$ & $\begin{array}{l}\text { MBO } \\
\text { land- } \\
\text { bouw }\end{array}$ & $\begin{array}{l}\text { MBO } \\
\text { tech- } \\
\text { niek }\end{array}$ & $\begin{array}{c}\text { MBO } \\
\text { eco- } \\
\text { nomie }\end{array}$ & $\begin{array}{c}\text { MBO } \\
\text { dienst } \\
\text { verl./ } \\
\text { verz }\end{array}$ & $\begin{array}{l}\text { MBO } \\
\text { overig }\end{array}$ & Totaal \\
\hline$\%$ & $\%$ & $\%$ & $\%$ & $\%$ & $\%$ & $\%$ & $\%$ & $\%$ & $\%$ & $\%$ & $\%$ & $\%$ \\
\hline 20 & - & 29 & 26 & 26 & 27 & - & 14 & 14 & 15 & 14 & - & 19 \\
\hline 44 & - & 50 & 36 & 41 & 45 & - & 28 & 30 & 24 & 36 & - & 30 \\
\hline 35 & - & 32 & 34 & - & 23 & - & 22 & 10 & 19 & 17 & - & 22 \\
\hline 32 & - & 42 & 49 & 49 & 34 & - & 59 & 64 & 69 & 46 & - & 54 \\
\hline 42 & - & 39 & 49 & 33 & 50 & - & 32 & 33 & 33 & 31 & - & 37 \\
\hline 28 & - & 49 & 47 & 39 & 51 & - & 50 & 48 & 48 & 42 & - & 45 \\
\hline 32 & - & 21 & 25 & 42 & 23 & - & 16 & 20 & 28 & 28 & - & 25 \\
\hline 36 & - & 36 & 29 & 40 & 57 & - & 17 & 26 & 39 & 45 & - & 34 \\
\hline 26 & - & 22 & 18 & 28 & 31 & - & 19 & 24 & 40 & 27 & - & 28 \\
\hline 44 & - & 36 & 29 & 40 & 57 & - & 30 & 37 & 40 & 36 & - & 37 \\
\hline 43 & - & 44 & 40 & 52 & 59 & - & 39 & 49 & 49 & 46 & - & 47 \\
\hline 33 & - & 50 & 47 & 55 & 61 & - & 35 & 51 & 58 & 56 & - & 51 \\
\hline 33 & - & 50 & 38 & 30 & 56 & - & 50 & 51 & 43 & 46 & - & 41 \\
\hline 53 & - & 36 & 47 & 30 & 61 & - & 38 & 42 & 51 & 40 & - & 48 \\
\hline 42 & - & 40 & 55 & 34 & 59 & - & 50 & 55 & 47 & 38 & - & 48 \\
\hline 35 & - & 51 & 41 & 46 & 59 & - & 42 & 39 & 40 & 31 & - & 42 \\
\hline 61 & - & 61 & 70 & 65 & 74 & - & 61 & 67 & 68 & 66 & - & 67 \\
\hline 25 & - & 35 & 25 & 36 & 24 & - & 29 & 35 & 42 & 20 & - & 30 \\
\hline 38 & - & 32 & 26 & 27 & 31 & - & 17 & 22 & 21 & 19 & - & 26 \\
\hline 19 & - & 35 & 28 & 22 & 38 & - & 24 & 32 & 29 & 25 & - & 28 \\
\hline
\end{tabular}


Tabel 29A

Potentiële mobiliteit van werkende schoolverlaters per opleidingscluster

Opleidingscluster

Totaal

$\mathrm{N}=100 \%$

$\%$

\begin{tabular}{ll}
\hline AVO & 19 \\
MAVO & 23 \\
HAVO & 19 \\
WWO & 11 \\
VBO & 10 \\
landbouw & 11 \\
techniek & 10 \\
economie & \\
dienstverlening/verzorging & 16 \\
overig &
\end{tabular}

MBO-kort

landbouw

techniek

economie

dienstverlening/verzorging

overig

MBO-tussen en -lang

landbouw

techniek

economie

dienstverlening/verzorging

overig

Totaal

- = geen gegevens vanwege kleine aantallen

Toelichting

Schoolverlaters worden als potentieel mobiel aangemerkt als zij de afgelopen 4 weken iets hebben gedaan om aan ander werk te komen of in afwachting zijn van reeds lopende sollicitatie(s).

Het gaat hier alleen om werkende schoolverlaters die niet doorstromen naar het voltijd dagonderwijs. 
Tabel 29B

Potentiële mobiliteit van werkende schoolverlaters per opleidingsrichting

Opleidingsrichting

Totaal

$\mathrm{N}=100 \%$

$\%$

AVO

MAVO

23

146

HAVO

VWO

VBO

landbouw

bouwtechniek

mechanische techniek

elektrotechniek

motorvoertuigentechniek

consumptieve techniek

installatietechniek

grafische techniek

overig techniek

administratie

verkoop

handel

verzorging

uiterlijke verzorging

mode en kleding

overig

MBO-kort

landbouw

elektrotechniek

motorv. techniek

consumptieve techniek

19

9

werktuigbouw

overig techniek

(detail)handel

administratie

verzorging

overig dienstverlening/verzorging

overig

MBO-tussen en -lang

plantenteelt

veehouderij

levensmiddelentechnologie

bloemschikken

dierenverzorging

groene ruimte

overig landbouw

bouwkunde

elektrotechniek

werktuigbouwkunde

weg- en waterbouwkunde

motorvoertuigentechniek

mechanische techniek

grafische techniek 
Tabel 29B (vervolg)

Potentiële mobiliteit van werkende schoolverlaters per opleidingsrichting

Opleidingsrichting

Totaal

$\mathrm{N}=100 \%$

$\%$

proces- en laboratoriumtechniek

35

39

nautisch

mode \& kleding (techn)

-

overig techniek

29

administratie

27

secretariaat

commercieel

economisch-juridisch

vrije afstudeerrichting

toerisme en recreatie

logistiek

(detail)handel

horeca

overig economie

agogisch werk

verzorging

assistenten gezondheidszorg

mode \& kleding (verz)

activiteitenbegeleiding

facilitaire dienstverlening

uiterlijke verzorging

sociale arbeid

verpleging

overig dienstverlening/verzorging

overig

Totaal

- = geen gegevens vanwege kleine aantallen

\section{Toelichting}

Schoolverlaters worden als potentieel mobiel aangemerkt als zij de afgelopen 4 weken iets hebben gedaan om aan ander werk te komen of in afwachting zijn van reeds lopende sollicitatie(s).

Het gaat hier alleen om werkende schoolverlaters die niet doorstromen naar het voltijd dagonderwijs. 
Tabel 30A

Deelname aan een aanvullende opleiding of cursus door werkenden per opleidingscluster

\begin{tabular}{|c|c|c|c|}
\hline Opleidingscluster & $\begin{array}{c}\text { na het verlaten } \\
\text { opleiding } \\
\%\end{array}$ & $\begin{array}{c}\text { op dit moment } \\
\%\end{array}$ & $\begin{array}{c}\text { Totaal } \\
\mathrm{N}=100 \%\end{array}$ \\
\hline AVO & 39 & 16 & 319 \\
\hline MAVO & 35 & 19 & 146 \\
\hline HAVO & 38 & 6 & 112 \\
\hline WWO & 50 & 26 & 61 \\
\hline VBO & 14 & 5 & 810 \\
\hline landbouw & 17 & 6 & 35 \\
\hline techniek & 14 & 5 & 551 \\
\hline economie & 15 & 6 & 98 \\
\hline dienstverlening/verzorging & 14 & 6 & 120 \\
\hline overig & - & - & - \\
\hline MBO-kort & 23 & 12 & 426 \\
\hline landbouw & 18 & 9 & 11 \\
\hline techniek & 13 & 6 & 169 \\
\hline economie & 34 & 20 & 183 \\
\hline dienstverlening/verzorging & 12 & 2 & 44 \\
\hline overig & - & - & - \\
\hline MBO-tussen en -lang & 30 & 17 & 1580 \\
\hline landbouw & 27 & 12 & 113 \\
\hline techniek & 30 & 15 & 436 \\
\hline economie & 38 & 24 & 539 \\
\hline dienstverlening/verzorging & 23 & 11 & 475 \\
\hline overig & - & - & - \\
\hline Totaal & 26 & 13 & 3135 \\
\hline
\end{tabular}

\section{Toelichting}

Vragen in de enquête:

- Heb je na het verlaten van je schoolopleiding een aanvullende opleiding of cursus gevolgd?

- Volg je op dit moment een aanvullende opleiding of cursus?

Het gaat hier alleen om werkende schoolverlaters die niet doorstromen naar het voltijd dagonderwijs. 
Tabel 30B

Deelname aan een aanvullende opleiding of cursus door werkenden per opleidingsrichting

Opleidingsrichting

\section{na het verlaten opleiding}

\section{AVO}

MAVO

HAVO

VWO

VBO

landbouw

bouwtechniek

mechanische techniek

elektrotechniek

motorvoertuigentechniek

consumptieve techniek

installatietechniek

grafische techniek

overig techniek

administratie

verkoop

handel

verzorging

uiterlijke verzorging

mode en kleding

overig

MBO-kort

landbouw

elektrotechniek

motorv. techniek

consumptieve techniek

werktuigbouw

overig techniek

(detail)handel

administratie

verzorging

overig dienstverlening/verzorging

overig

MBO-tussen en -lang

plantenteelt

veehouderij

levensmiddelentechnologie

bloemschikken

dierenverzorging

groene ruimte

overig landbouw

bouwkunde

elektrotechniek

werktuigbouwkunde

weg- en waterbouwkunde

motorvoertuigentechniek

mechanische techniek

grafische techniek
$\%$

35

38

50

17

16

29

15

6

5

$-$

-

-

-

$-$

17

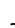

op dit moment

Totaal

$\mathrm{N}=100 \%$

$\%$

$\begin{array}{rr}19 & 146 \\ 6 & 112 \\ 26 & 61\end{array}$


Tabel 30B (vervolg)

Deelname aan een aanvullende opleiding of cursus door werkenden per opleidingsrichting

\section{Opleidingsrichting}

\section{na het verlaten opleiding}

$\%$

proces- en laboratoriumtechniek

nautisch

mode \& kleding (techn)

overig techniek

administratie

secretariaat

commercieel

economisch-juridisch

vrije afstudeerrichting

toerisme en recreatie

logistiek

(detail)handel

horeca

overig economie

agogisch werk

verzorging

assistenten gezondheidszorg

mode \& kleding (verz)

activiteitenbegeleiding

facilitaire dienstverlening

uiterlijke verzorging

sociale arbeid

verpleging

overig dienstverlening/verzorging

overig

Totaal

- = geen gegevens vanwege kleine aantallen op dit moment

$\%$

37

35

35

51

35

43

43

52

39

24

36

25

33

20

16
30

31

12

22

51

37

16

-

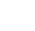

12

-

21

12

31

21

28

$-$

28

18

17

24

12

25

9

6

16

18

7

12

29

15

5

13
Totaal

$\mathrm{N}=100 \%$

(2)

40

40

34

43

67

88

46

$-$

22

38

3

153

37

73

109

129

80

37

28

21

24

14

23

26

Toelichting

Vragen in de enquête:

- Heb je na het verlaten van je schoolopleiding een aanvullende opleiding of cursus gevolgd?

- Volg je op dit moment een aanvullende opleiding of cursus?

Het gaat hier alleen om werkende schoolverlaters die niet doorstromen naar het voltijd dagonderwiis. 
Tabel 31A

De marktpositie per opleidingscluster

\begin{tabular}{|c|c|c|c|}
\hline Opleidingscluster & $\begin{array}{l}\text { vinden van } \\
\text { werk }\end{array}$ & $\begin{array}{l}\text { kwaliteit } \\
\text { van werk }\end{array}$ & $\begin{array}{l}\text { structureel } \\
\text { risico }\end{array}$ \\
\hline AVO & gemiddeld & slecht & weinig \\
\hline MAVO & goed & slecht & weinig \\
\hline HAVO & slecht & slecht & - \\
\hline WWO & goed & - & - \\
\hline VBO & goed & gemiddeld & veel \\
\hline landbouw & erg goed & slecht & weinig \\
\hline techniek & goed & gemiddeld & erg veel \\
\hline economie & slecht & slecht & - \\
\hline dienstverlening/verzorging & goed & gemiddeld & weinig \\
\hline overig & - & - & - \\
\hline MBO-kort & slecht & gemiddeld & gemiddeld \\
\hline landbouw & gemiddeld & gemiddeld & - \\
\hline techniek & gemiddeld & goed & veel \\
\hline economie & slecht & slecht & weinig \\
\hline dienstverlening/verzorging & erg slecht & gemiddeld & - \\
\hline overig & slecht & - & - \\
\hline MBO-tussen en -lang & gemiddeld & erg goed & gemiddeld \\
\hline landbouw & goed & goed & gemiddeld \\
\hline techniek & gemiddeld & erg goed & veel \\
\hline economie & gemiddeld & goed & gemiddeld \\
\hline dienstverlening/verzorging & gemiddeld & goed & gemiddeld \\
\hline overig & - & - & - \\
\hline
\end{tabular}

- = geen gegevens vanwege kleine aantallen 
Tabel 31B

De marktpositie per opleidingsrichting

\begin{tabular}{|c|c|c|c|}
\hline Opleidingsrichting & $\begin{array}{l}\text { vinden van } \\
\text { werk }\end{array}$ & $\begin{array}{l}\text { kwaliteit } \\
\text { van werk }\end{array}$ & $\begin{array}{l}\text { structureel } \\
\text { risico }\end{array}$ \\
\hline \multicolumn{4}{|l|}{ AVO } \\
\hline MAVO & goed & slecht & weinig \\
\hline HAVO & slecht & slecht & - \\
\hline WWO & goed & - & - \\
\hline \multicolumn{4}{|l|}{ VBO } \\
\hline landbouw & erg goed & slecht & weinig \\
\hline bouwtechniek & goed & gemiddeld & erg veel \\
\hline mechanische techniek & goed & gemiddeld & veel \\
\hline elektrotechniek & goed & - & - \\
\hline motorvoertuigentechniek & goed & gemiddeld & gemiddeld \\
\hline consumptieve techniek & gemiddeld & slecht & weinig \\
\hline installatietechniek & - & - & - \\
\hline grafische techniek & - & - & - \\
\hline overig techniek & - & - & - \\
\hline administratie & - & - & - \\
\hline verkoop & - & - & - \\
\hline handel & - & - & - \\
\hline verzorging & goed & gemiddeld & weinig \\
\hline uiterlijke verzorging & - & - & - \\
\hline mode en kleding & - & - & - \\
\hline overig & - & - & - \\
\hline \multicolumn{4}{|l|}{ MBO-kort } \\
\hline landbouw & gemiddeld & gemiddeld & - \\
\hline elektrotechniek & gemiddeld & goed & erg veel \\
\hline motorv. techniek & erg goed & - & - \\
\hline consumptieve techniek & gemiddeld & gemiddeld & gemiddeld \\
\hline werktuigbouw & gemiddeld & - & - \\
\hline overig techniek & gemiddeld & - & - \\
\hline (detail)handel & gemiddeld & slecht & - \\
\hline administratie & erg slecht & gemiddeld & gemiddeld \\
\hline verzorging & erg slecht & slecht & - \\
\hline overig dienstverlening/verzorging & - & - & - \\
\hline overig & slecht & - & - \\
\hline \multicolumn{4}{|l|}{ MBO-tussen en -lang } \\
\hline plantenteelt & erg goed & erg goed & gemiddeld \\
\hline veehouderij & goed & goed & veel \\
\hline levensmiddelentechnologie & goed & goed & gemiddeld \\
\hline bloemschikken & erg goed & goed & erg veel \\
\hline dierenverzorging & slecht & goed & - \\
\hline groene ruimte & goed & erg goed & gemiddeld \\
\hline overig landbouw & - & - & - \\
\hline bouwkunde & gemiddeld & erg goed & erg veel \\
\hline elektrotechniek & gemiddeld & erg goed & veel \\
\hline werktuigbouwkunde & goed & erg goed & veel \\
\hline weg- en waterbouwkunde & goed & - & - \\
\hline motorvoertuigentechniek & erg goed & erg goed & erg veel \\
\hline mechanische techniek & erg goed & - & - \\
\hline grafische techniek & gemiddeld & erg goed & gemiddeld \\
\hline proces- en laboratoriumtechniek & goed & erg goed & veel \\
\hline
\end{tabular}


Tabel 31B (vervolg)

De marktpositie per opleidingsrichting

\begin{tabular}{llll} 
Opleidingsrichting & $\begin{array}{l}\text { vinden van } \\
\text { werk }\end{array}$ & $\begin{array}{l}\text { kwaliteit } \\
\text { van werk }\end{array}$ & $\begin{array}{l}\text { structureel } \\
\text { risico }\end{array}$ \\
\hline nautisch & - & - & - \\
mode \& kleding & gemiddeld & gemiddeld & weinig \\
overig techniek & gemiddeld & erg goed & gemiddeld \\
administratie & goed & erg goed & gemiddeld \\
secretariaat & gemiddeld & erg goed & gemiddeld \\
commercieel & gemiddeld & goed & weinig \\
economisch-juridisch & - & - & - \\
vrije afstudeerrichting & slecht & goed & weinig \\
toerisme en recreatie & gemiddeld & erg goed & gemiddeld \\
logistiek & goed & - & - \\
(detail)handel & gemiddeld & goed & weinig \\
horeca & erg goed & erg goed & erg weinig \\
overig economie & gemiddeld & goed & gemiddeld \\
agogisch werk & slecht & gemiddeld & gemiddeld \\
verzorging & goed & goed & gemiddeld \\
assistenten gezondheidszorg & gemiddeld & erg goed & gemiddeld \\
mode en kleding & gemiddeld & gemiddeld & veel \\
activiteitenbegeleiding & slecht & goed & veel \\
facilitaire dienstverlening & gemiddeld & gemiddeld & - \\
uiterlijke verzorging & goed & gemiddeld & veel \\
sociale arbeid & gemiddeld & gemiddeld & weinig \\
verpleging & goed & goed & erg weinig \\
overig dienstverlening/verzorging & - & - & - \\
overig & - & - & - \\
\hline & & & \\
\hline & & & \\
\hline
\end{tabular}

- = geen gegevens vanwege kleine aantallen 


\section{Enkele centrale begrippen}

\section{Allochtoon}

Iemand die zichzelf niet tot de Nederlandse bevolkingsgroep rekent.

\section{Beroep}

Alle beroepen zijn ingedeeld volgens de Standaard Beroepenclassificatie 1992 van het CBS. In dit rapport wordt met name uitgegaan van de indeling in 121 beroepsgroepen.

\section{Beroepsbevolking}

Tot de beroepsbevolking behoren degenen die:

- ten minste 12 uur per week werken;

- werk hebben aanvaard waardoor zij ten minste 12 uur per week gaan werken;

- ten minste 12 uur per week willen werken, daardoor beschikbaar zijn en daartoe tevens activiteiten ontplooien.

In deze rapportage wordt daartoe tevens als voorwaarde gesteld dat het moet gaan om schoolverlaters die niet doorstromen naar he voltijd dagonderwijs.

Publikatie:

Centraal Bureau voor de Statistiek, Enquête Beroepsbevolking 1994, Voorburg/Heerlen, 1995.

\section{Bedrijfssector}

Alle bedrijven zijn ingedeeld volgens de Standaard Bedrijfsindeling 1993 van het CBS. In dit rapport wordt met name uitgegaan van de indeling in 211 bedrijfsgroepen.

\section{Bruto loon}

Het bruto maandloon heeft betrekking op de baan waarin men het meeste aantal uren werkt, inclusief toeslagen voor ploegendienst of fooien, maar exclusief vakantiegeld, inkomen uit overwerk of inkomen op basis van een uitkering. Het bruto uurloon is gelijk aan het bruto maandloon, gedeeld door het contractuele aantal arbeidsuren in de baan waarin men de meeste uren werkt, vermenigvulgdigd met de factor 12/52.

\section{Conjunctuurgevoeligheid}

De conjunctuurgevoeligheid van de werkgelegenheid geeft aan in welke mate de werkgelegenheid voor mensen met een bepaalde opleiding gevoelig is voor veranderingen van de economische situatie. De conjunctuurgevoeligheid wordt bepaald door de sectorale werkgelegenheidsfluctuaties in het verleden te relateren aan de mate waarin een opleiding in de verschillende bedrijfssectoren is vertegenwoordigd.

\section{Flexibele arbeidsrelatie}

Van een flexibele arbeidsrelatie is sprake bij uitzendwerk, een oproep- of nulurencontract, een werkervaringsproject of indien men in loondienst is bij een werkgever of op basis van leer-werk-overeenkomst werkzaam is met een contract van maximaal een half jaar. 
Intredewerkloosheid

Het aantal maanden dat schoolverlaters aangeven in totaal werkloos te zijn geweest sinds het verlaten van de opleiding.

\section{$\overline{\text { Onderbenutting }}$}

Van onderbenutting is sprake als het opleidingsniveau dat minimaal vereist is voor de functie lager is dan het feitelijke onderwijsniveau.

\section{Opleiding}

Alle opleidingen zijn ingedeeld volgens een daarvoor speciaal ontworpen classificatie. In dit rapport wordt onderscheid gemaakt tussen vier schooltypen (AVO, VBO, MBOkort en MBO-tussen en -lang), 18 opleidingsclusters (bijvoorbeeld VBO techniek) en 69 opleidingsrichtingen (bijvoorbeeld VBO elektrotechniek).

\section{Uitwijkmogelijkheden}

De mate waarin men met een bepaalde opleiding terecht kan komen in andere bedrijfsof beroepsgroepen. Daarvoor wordt gebruik gemaakt van de bedrijfs- en beroepsgroepenspreiding die worden bepaald aan de hand van de Gini-Hirschman coëfficiënt. Deze index is gelijk aan 0 indien er een volledige concentratie van de werkenden in één bedrijfsgroep, respectievelijk beroepsgroep is en gelijk aan 1 indien de werkenden juist precies gelijk verdeeld zijn over alle bedrijfs- of beroepsgroepen.

\section{Werkende}

Iemand die ten minste 12 uur per week betaald werk verricht. In deze rapportage wordt daarbij tevens als voorwaarde gesteld dat het moet gaan om schoolverlaters die niet doorstromen naar het voltijd dagonderwijs.

\section{Werkloosheid}

In deze rapportage wordt uitgegaan van de Geregistreerde werkloosheid confrom CBSdefinitie, dat wil zeggen:

- ingeschreven bij een arbeidsbureau;

- niet of minder dan 12 uur per week werken;

- beschikbaar zijn voor een baan voor 12 uur of meer per week of werk hebben aanvaard waardoor men ten minste 12 uur per week gaat werken.

De werkloosheid wordt gerelateerd aan het aantal schoolverlaters dat tot de beroepsbevolking behoort en niet doorstroomt naar het voltijd dagonderwijs.

Publikatie:

Centraal Bureau voor de Statistiek, Enquête Beroepsbevolking 1994, Voorburg/Heerlen, 1995. 
Koppelschema Kerngegevens 1995/Schoolverlaters op de arbeidsmarkt 1994

\begin{tabular}{lc}
1995 & $\mathbf{1 9 9 4}$ \\
\hline 1 & 1 \\
2 & 2 \\
3 & 3 \\
4 & 4 \\
5 & 6 \\
6 & 5 \\
7 & 7 \\
8 & 26 \\
9 & 28 \\
10 & 8 \\
11 & 10 \\
12 & 13 \\
13 & 11 \\
14 & 19 \\
15 & 20 \\
16 & 17 \\
17 & 17 \\
18 & 18 \\
19 & 18 \\
20 & 18 \\
21 & 22 \\
22 & 16 \\
23 & 24 \\
24 & 21 \\
25 & 15 \\
26 & 23 \\
27 & 25 \\
28 & 27 \\
29 & 14 \\
30 & 29 \\
31 & 30 \\
\hline &
\end{tabular}




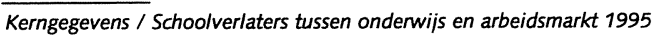


Beste oud-leerling,

Vorig jaar heb je een schoolopleiding beëindigd. De naam van deze opleiding staat hieronder bij vraag 1a afgedrukt. De school is geïnteresseerd in de envaringen die je na deze opleiding hebt opgedaan. Bijvoorbeeld of je na deze opleiding bent gaan werken of een andere opleiding bent gaan volgen. Om op dit soort vragen een antwoord te krijgen, willen wij je vragen deze vragenlijst in te vullen. De school werkt hiervoor met een groot aantal andere scholen in Nederland samen in het project "Registratie van de Uitstroom en Bestemming van Schoolverlaters (RUBS)".

Wanneer je deze vragenlijst invult, help je de school om de oplejding beter af te stemmen op werk of vervolgonderwijs. De uitkomsten zijn ook erg belangrijk voor jongeren die nog een keuze gaan maken voor een bepaalde opleiding. Zij kunnen dan zien welke mogelijkheden er zijn na het volgen van de verschillende opleidingen.

Het is belangrijk dat zoveel mogelijk mensen de vragenlijst invullen. Ook als je van deze opleiding géén diploma hebt behaald.

De ingevulde vragenlijst kun je zonder postzegel in de bijgevoegde antwoordenvelop opsturen naar DESAN Marktonderzoek.

De ingevulde vragenlijst komt dus niet meer terug op school. De gegevens worden anoniem verwerkt, zodat straks niemand kan zien wat jij hebt ingevuld. Jouw eigen gegevens worden alleen aan de school doorgegeven wanneer je daar geen bezwaar tegen hebt. Dit kun je aangeven bij vraag $22 a$.

Wij hopen dat je mee wilt werken aan dit onderzoek en de vragenlijst zo spoedig mogelijk wilt invullen en opsturen.

Bedankt yoor je medewerking!

\section{Toelichting voor het invullen van de vragenlijst}

- Lees eerst de gehele vraag. Kruis daarna een hokje aan of vul je antwoord op de stippellijntjes in. Je mag bij de vragen steeds maar één hokje aankruisen.

- Soms hoef je een aantal vragen niet in te vullen. Let daarom goed op naar welke vraag je wordt doorgestuurd.

Bijvoorbeeld $\rightarrow$ ga naar $3 b$ betekent dat je met vraag $3 b$ verder moet gaan.

\section{Opleiding vorig schooljaar (1993/1994)}

1 a. Hiemaast staat de dagopleiding die je vorig. schooljaar (1993/1994) hebt gevolgd. is de naam van de opleiding juist?

ja

nee, ik heb vorig schooljaar een andere dagopleiding gevolgd,

namelijk :

begin: maand: ..jaar: 19

b. Wanneer ben je met deze opleiding begonnen? En in welke klas?

c. Wanneer heb je deze opleiding verlaten? En in welke klas?

d. Heb je van deze opleiding het diploma of een (deel-)certificaat behaald? klas: .

einde: maand: jaar: 19

klas:

volledig diploma (inclusief alle praktijkstages)

alléén (deel-)certificaten

alléen theorie-examen

géén diploma

\section{Eerdere opleiding (vóor schooljaar 1993/1994)}

1 e. Op grond van welke vooropleiding ben je toegelaten tot de opliaiding van vraag $1 a$ ?

f. Heb je van deze vooropleiding een diploma of (deel-)certificaat behaald? vooropleiding: (bijv. MAVO, HAVO, LTS-bouw, KMBO-horeca)

volledig diploma (inclusief alle praktijkstages) alléén (deel-)certificaten alléen theorie-examen géén diploma of (deel-)certificaat 
Na de opleiding (van schooljaar 1993/1994)

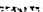

2 a. Wat wilde jevorig jaar direct na de opleiding gaari doen?

\begin{tabular}{ll}
\hline alléén werken & $\rightarrow$ ga naar $2 b$ \\
alléén verder leren & $\rightarrow$ ga naar $2 c$ \\
werken en leren & \\
(zoals leerlingwezen of in-service opleiding) & $\rightarrow$ ga naar $2 b$ \\
iets anders & $\rightarrow$ ga naar $2 c$
\end{tabular}

b. Wanneer ben je begomen met het actief zoeken naar werk? - $\cdots, \cdots$ (je kunt ook al metzoeken zjjn begonnen vóórdat je deze opleiding hebt verlaten)

c. Hoeveel maanden ben je in totaal werkloos geweest na het verlaten van deze opleiding?

maand: jaar: 19

\section{Huidige bezigheden}

3 a. Volg je op dit moment:

- een opleiding in het leartingmerean of

- een in-service opleiding in de verpleging of

(bijv. voor automonteur, schilder, restaurantkok, A-verpleegkundige of ziekenverzorgende)?

b. Welke opleiding volg je op dit moment in het leerlingwezen of als in-service opleiding? (bijv. automonteur, lasser, Z-verpleegkundige)

c. Alléen voor personen in het teenlingwezen: ...... Is dit een primaire, secundaire (voortgezette) of tertiaire opleiding in het leerlingwezen?

d. Alléen voor personen in het leerlingstelsel: Wat is de naam van het leerlingstelsel waartoe deze opleiding behoort? (bij. ECABO, SOM, VEV, OVDB, VOLLT)

e. Heb je naast de opleiding op school ook nog werk of een stageplaats in het kader van het leerlingwezen of een in-service opleiding? ja, betaald werk

ja, werk of stage met alléén onkosten- of stagevergoeding

$3 \mathrm{ja}$, onbetaald werk

nee, volg alleen schoolgedeelte $\rightarrow$ ga naar $6 a$

$\rightarrow$ ga naar $6 a$

$\rightarrow$ ga naar $6 a$

$\rightarrow$ ga naar $6 a$
4. Wat doe je op dit moment?

Geef hiemaast je voomaamste bezigheid aan.

Let op: maar één antwoord mogelijk! ik heb betaald werk

(ook beroepsmilitair of $\mathrm{KW}$-er) $\quad \rightarrow$ ga naar $6 a$

ik ben scholier/student $\quad \rightarrow$ ga naar $5 a$

ik ben werkloos $\quad \rightarrow$ ga naar $6 a$

ik doe onbetaald werk $\quad \rightarrow$ ga naar $6 a$

ik doe het huishouden $\quad \rightarrow$ ga naar $6 a$

ik vervul militaire of vervangende dienst $\quad \rightarrow$ ga naar 15

ik doe iets anders,

namelijk:

$\rightarrow$ ga naar $6 a$ 


\section{Huidige opleiding}

5 a. Welke opleiding volg je op dit moment? (bijv. HTS, HEAO, PABO, MTS, MDGO)

b. Welke vakrichting volg je binnen deze opleiding? (bij. bouwkunde, commercieel, verpleging)

c. Alléén invullen als je naar MBO bent gegaan: Volg je op dit moment de korte, tussen- of lange variant van de MBO-opleiding? naam opleiding:

naam richting:

korte MBO-opleiding (2-jarig)

tussen MBO-opleiding (3-jarig)

lange MBO-opleiding (4-jarig)

6 a. Heb je op dit moment betaald werk? Als je meerdere banen hebt, dan gaat het om het totaal aantal uren dat je werkt.

ja, voor 12 uur of meer per week

ja, voor minder dan 12 uur per week

nee, op dit moment geen betaald werk

ja

nee

ik heb al voldoende (ander) werk gevonden $\rightarrow$ ga naar 7

$\rightarrow$ ga naar $6 b$

$\rightarrow$ ga naar $6 b$

$\rightarrow$ ga naar 15

$\rightarrow$ ga naar 15

$\rightarrow$ ga naar 15

\section{Huidig werk en beroep}

7. Heb je op dit moment één of meerdere betaalde banen?

één baan meerdere banen

$\gg \quad$ Heb je nu meer dan 1 baan, dan gaan de volgende vragen over de baan waarin je de meeste uren werkt. Ga nu door met vraag 8 a.

8 a. Is dit je eerste baan na het verlaten van de ja opleiding?

nee

b. Wanneer ben je in je huidige baan begonnen?

maand: jaar: 19

c. Hoe ben je aan je huidige baan gekomen?

Let op: maar één antwoord mogelijk!

1 via het arbeidsbureau

2 via een uitzendbureau

3. geschreven of gebeld op een advertentie

4 via familie, vrienden of kennissen

5 via eerder betaald werk, bijbaantje, interne vacature, dienstplicht

be werkgever heeft mij gevraagd en daar niet eerder gewerkt (bijv. op banenmarkt of open dag)

$[7$ open sollicitatie (zelf aan werkgever werk gevraagd)

$\bar{\square}$ via werkervaringsproject (bijv. Jeugdwerkgarantieplan)

zelf bedrijf begonnen of overgenomen (bijv. van ouders)

10: via docenten of vacaturebank school

"1 via stage

$\sqrt{12}$ anders, namelijk:

9 a. In wat voor dienstverband werk je?

Let op: maar éen antwoord mogelijk!

b. Voor hoe lang heb je een aanstelling?

Let op: maar één antwoord mogelijk! leer-werkovereenkomst (via leerlingwezen)

werk via uitzendbureau

loondienst bij werkgever

oproepkracht of nul-urencontract

werkenvaringsproject (bijv. Jeugdwerkgarantieplan)

werk in bedrijf ouders/partner

werk in eigen bedrijf of free-lance

tijdelijke baan voor maximaal 1 maand

tijdelijke baan voor meer dan 1, maar maximaal 3 maanden

tijdelijke baan voor meer dan 3, maar maximaal 6 maanden

tijdelijke baan voor meer dan 6, maar maximaal 12 maanden

tijdelijke baan voor meer dan 12 maanden

vaste baan of proeftijd voor vaste baan 
10a. Hoe heet je huidige beroep of functie? (bijv. lasser, verkoper, automonteur, metselaar, tuinder, ober, secretaresse, ziekenverzorgende)

b. Wat zijn je voomaamste werkzaamheden? (bij. technisch tekenen, verkopen van kleding, schilderen, bloemen telen, boekhouden)

c. Geef je leiding aan andere medewerkers? Zo ja, aan hoeveel?

11a. Bij wat voor organisatie of bedrijf werk je? (bijv. machinefabriek, garagewerkplaats, kledingwinkel, hotel, ziekenhuis)

b. Op wat voor afdeling werk je? (bijv. montagehal, magazijn, loonadministratio, receptie, operatiekamer)

c. In welke plaats is dit bedrijf gevestigd? Het gaat om de vestiging waar jiij zelf werkt. Werk je in het buitenland, noem dan de naam van dit land.

d. Hoeveel mensen werken er ongeveer bij de organisatie of het bedrijf? Het gaat nu om alle werknemers van dit bedniff in Nedertand.

12a. Welk soort opleiding werd minimaal voor je huidige baan vereist?

Let op: maar één antwoord mogelijk!

b. Werd een speciale richting voor je huidige baan vereist? (bijv. elektrotechniek of verpleging)

13. Hoeveel uur werk je per week in je huidige baan (volgens je contract)?

- tel overwerk niet mee

- ga uit van de laatste maand

14. Hoeveel verdien je in je huidige baan ongeveer bruto per maand?

- tel toeslagen ploegendienst of fooien wel mee. - tel overwerk, vakantiegeld, uitkering niet mee geen leiding aan anderen

leiding aan 1 - 9 personen

leiding aan $10-49$ personen

leiding aan minimaal 50 personen

:

1 persoon

2 t/m 9 personen

$10 \mathrm{t} / \mathrm{m} 19$ personen

$20 \mathrm{t} / \mathrm{m} 49$ personen

$30 \mathrm{t} / \mathrm{m} 99$ personen

(. $100 \mathrm{t} / \mathrm{m} 499$ personen

$500 \mathrm{t} / \mathrm{m} 999$ personen

1000 personen of meer

1. lagere school voldoende

2 MAVO of LBO

3 leerlingwezen, in-service opleiding of $\mathrm{KMBO}$

4 HAVO, VWO of MBO

3 HBO of universiteit

ja, de richting die ik vorig jaar zelf heb gevolgd

ja, maar een andere richting dan die ik vorig jaar heb gevolgd

nee, een speciale richting werd niet vereist

uur per week

Als je in het leerlingwezen zit, tel je de uren op school niet mee.

$\mathrm{Vul}$ ' $\mathrm{O}$ ' in als je afgelopen maand geen betaald werk hebt gehad.

bruto gulden per maand

Ga uit van de laatste maand. Kijk eventueel op je loonstrookje.

\section{De vragen $15 \mathrm{t} / \mathrm{m} 23$ zijn yoor iedereen bestemd}

\section{De opleiding van vorig jaar achteraf bezien}

15. Hoe vind je de aansluiting tussen je opleiding van vorig jaar en je huidige bezigheden? (bijv. je huidige werk of vervolgopleiding)

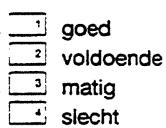


Moet daaraan in de opleiding die je vorigjaar hebt verlaten, méer, evenveel of minder aandacht worden besteed?

a. Vakkennis

b. Met cijfers werken (rekenen, wiskunde)

c. Informatica, automatisering

d. Gebruik van apparatuur en materialen

๑. Commerciële kennis, verkooptechniek

f. Correcte spelling, foutloos schrijven

g. Vreemde talen (Engels, Duits e.d.)

h. Een verslag of rapport schrijven

i. Spreekvaardigheid

j. Praktijkoriëntatie of stage

k. Beroepskeuze en/of studiekeuze

I. Leren solliciteren

$\mathrm{m}$. Weten hoe een bedrif is georganiseerd

n. Kennis van arbeidsvoorwaarden (CAO, wat te doen bij ontslag e.d.)

o. Zelfstandig werken

p. Organiseren, plannen

q. Onderscheiden van hoofd-eni bijzakken

r. Leren studeren (studieplainning, hüiswerk):

s. Samenwerken met collega's/medestudenten :

t. Omgaan met klanten, patiënten eid:

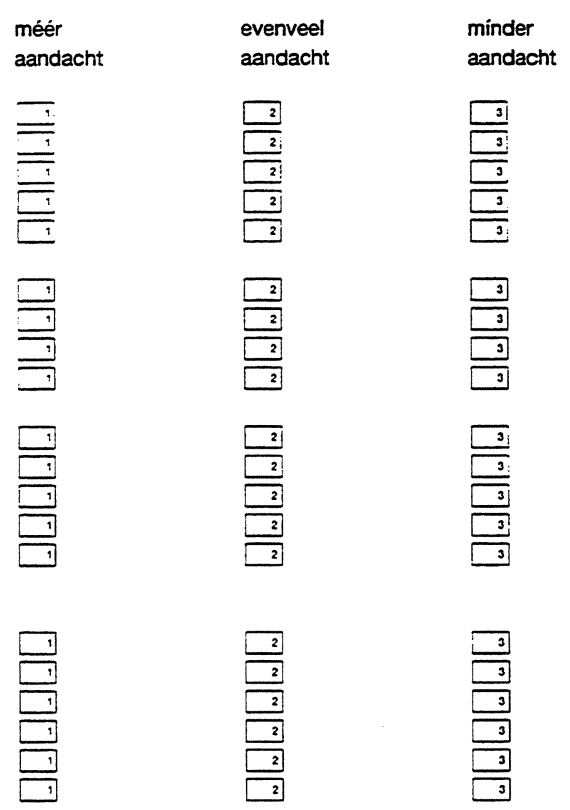

\section{Op zoek naar (ander) werk}

17a. Heb je in het afgelopen half jaar iets gedaan 1 ja

b. Heb je in de afgelopen 4 weken iets gedaan om aan (ander) werk te komen?

c. Stel, je vindt nú een (andere) baan

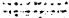

Hoe snel kun je daarmee dan beginnen?

binnen 2 weken

d. Waarom kun je niet binnen 2 woken beginnen?

1 vanwege opzeggen huidige baan 2 vanwege afronden vrijwilligerswerk 3 vanwege afronden opleiding/studie vanwege afronden militaire of vervangende dienstplicht 3 vanwege regelen kinderopvang 6. vanwege vakantie 7 vanwege ziekte . vanwege een andere reden, $\mathrm{nl}$ :

e. Ben je als werkzoekende ingeschreven bij het arbeidsbureau?

\section{Aanvullende opleiding of cursus}

Wij willen nu een aantal vragen stellen over aanvullende opleidingen of cursussen. Het gaat hierbij niet om de opleiding die je eventueel al bij vraag 3 of 5 hebt ingevuld, maar om vakcursussen of bedrijfsopleidingen (geen hobbycursus)

18a. Heb je na het vertaten van je schoolopleiding een aanvullende opleiding of cursus gevolgd?

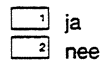

$$
\text { (........... }
$$

b. Volg je op dit moment een aanvullende opleiding of cursus?

\footnotetext{
$\rightarrow$ ga naar $18 b$

$\rightarrow$ ga naar 19

$\rightarrow$ ga naar $18 \mathrm{c}$

$\rightarrow$ ga naar 19
} 
c. Zo ja, welke opleiding of cursus volg je op dit moment?

d. Noem de belangrijkste ondemwerpen van de opleiding of cursus die je op dit moment volgt.

e. Hoe lang duurt deze opleiding of cursus in totaal?

Hoeveel uur besteed je wekelijks aan lestjjd en voorbereiding (bijvoorbeeld huiswerk of oefentijd) voor deze opleiding of cursus?

g. Wie betaalt de kosten (cursusgelden, boeken, reiskosten) van deze opleiding of cursus?

h. Wanneer volg je deze opleiding of cursus?

i. Waarom volg je deze opleiding of cursus? naam:

onderwerpen :

1 week of minder

van $1 \mathrm{t} / \mathrm{m} 4$ weken

van $2 t / m 3$ maanden

van $4 \mathrm{t} / \mathrm{m} 12$ maanden

langer dan 1 jaar

uur per week

ik zelf

mijn werkgever

ik zelf en mijn werkgever samen

anders (bijvoorbeeld het arbeidsbureau), namelijk:

in eigen tijd

in werktijd

in eigen tijd en werktijd

het is nodig om bij te blijven in mijn huidige baan

was nodig om mijn huidige baan te krijgen

het is nodig om hogerop te komen

ik wil in een ander soort baan gaan werken

ik heb dan meer kans op werk

andere reden, namelijk:

\section{Tot slot}

19. Wanneer ben je geboren?

20. Ben je man of vrouw?

21. Tot welke bevolkingsgroep reken jij jezelf? geboortemaand: jaar: $19 . . . . .$.

man

2 vrouw

Nederiandse

2 Antilliaanse/Arubaanse

Surinaamse

Turkse

Marokkaanse

andere, namelijk:

22a. De school ontvangt alléén anonieme resultaten Vind je het goed wanneer ook niet-anonieme. antwoorden aan je vroegere schoot worden: doorgegeven?

ja, ik vind dit goed

nee, ik heb hier bezwaar tegen

b. In de toekomst wordt dit onderzoek misschien herhaald. Daavoor is je naam en adres nodig. Daarom vragen wij jou hiemaast je naam en adres op te geven. Alvast bedankt.

naam:

straat $+n r$.

postcode + plaats:

ingevuld in maand: .1995

Opmerkingen over de school, het werk, de vragenlijst e.d.

\section{Hartelijk bedankt voor het invullen!}

Stuur de vragenlijst zo snel mogelijk op in de antwoordenvelop (een postzegel is niet nodig). 
